\author{
Universidade de São Paulo \\ FFCLRP - Departamento de Física e Matemática
}

Programa de pós-graduação de Física Aplicada à Medicina e Biologia

\title{
Caracterização bioquímica de células sadias e neoplásicas através de espectroscopia vibracional
}

\author{
LEILA BÜTTNER MOSTAÇO-GUIDOLIN
}

Dissertação de Mestrado apresentada à Faculdade de Filosofia, Ciências e Letras de Ribeirão Preto da Universidade de São Paulo para obtenção do título de Mestre em Ciências.

Ribeirão Preto - SP

2009 



\author{
Universidade de São Paulo \\ FFCLRP - Departamento de Física e Matemática
}

Programa de pós-graduação de Física Aplicada à Medicina e Biologia

\title{
Caracterização bioquímica de células sadias e neoplásicas através de espectroscopia vibracional
}

\author{
LEILA BÜTTNER MOSTAÇO-GUIDOLIN
}

Orientador: Prof. Dr. Luciano Bachmann

Dissertação de Mestrado apresentada à Faculdade de Filosofia, Ciências e Letras de Ribeirão Preto da Universidade de São Paulo para obtenção do título de Mestre em Ciências.

Ribeirão Preto - SP

2009 
Autorizo a reprodução e divulgação total e parcial deste trabalho, por qualquer meio, convencional ou eletrônico, desde que citada a fonte.

\section{Ficha catalográfica}

Mostaço-Guidolin, Leila Büttner

Caracterização Bioquímica de Células Sadias e Neoplásicas através de Espectroscopia Vibracional. Ribeirão Preto, 2009.

134p. : il. ; $30 \mathrm{~cm}$.

Dissertação de Mestrado, apresentada à Faculdade de Filosofia, Ciências e Letras de Ribeirão Preto / USP.

Área de concentração: Física Aplicada à Medicina e Biologia.

Orientador: Bachamnn, Luciano

1. Espectroscopia 2. FTIR 3. Células 4. Neoplásicas 


\section{Folha de Aprovação}

Leila Büttner Mostaço-Guidolin

Caracterização bioquímica de células sadias e neoplásicas através de espectroscopia vibracional

Dissertação de Mestrado apresentada à Faculdade de Filosofia, Ciências e Letras de Ribeirão Preto da Universidade de São Paulo para obtenção do título de Mestre em Ciências.

Área de concentração: Física Aplicada à Medicina e Biologia.

Aprovado em 28/08/2009

Banca Examinadora:

Prof. Dr. Luciano Bachmann

Departamento de Física e Matemática - FFCLRP - USP

Prof. Dr. Airton Abrahão Martin

Universidade do Vale do Paraíba - UNIVAP

Prof. Dr. Gilberto Úbida Leite Braga

Faculdade de Ciências Farmacêuticas de Ribeirão Preto - USP 
- By failing to prepare, you are preparing to fail. - Benjamin Franklin

À memória de meu pai, Fernando, à minha super-mãe, Eliane, ao meu irmão Guilherme e ao meu grande amor, Luiz. 


\section{Resumo}

Os mecanismos moleculares relacionados ao desenvolvimento e à progressão de cânceres são extremamente complexos. A espectroscopia no infravermelho por transformada de Fourier (FTIR) é capaz de detectar alterações bioquímicas de materiais biológicos, permitindo a importante caracterização e diferenciação de células. Através da observação individual de bandas de absorção, é possível identificar semelhanças e diferenças entre células, através das quais é possível entender parte das alterações que ocorrem em linhagens celulares pertencentes à um mesmo grupo de doenças ou entre células sadias e neoplásicas. Neste trabalho foram caracterizados quatro conjuntos de células neoplásicas através da espectroscopia por FTIR. Cada conjunto foi composto por duas linhagens celulares: o primeiro conjunto foi composto por uma linhagem de melanoma murino (B16F10) e melanoma humano (C8161); o segundo conjunto continha uma linhagem de adenocarcinoma de cólon (HT-29) e outra de adenocarcinoma cérvix (HeLa); o terceiro conjunto foi composto por duas linhagens de câncer de mama humano (SKBr3 e MCF-7); por fim, o último conjunto possuía uma linhagem de leucemia humana do tipo T (JURKAT) e células mononucleares de sangue periférico (PBMC). Todas as linhagens foram adquiridas da American Type Culture Collection (ATCC, Manassas, VA, USA). A análise bioquímica foi conduzida através de um espectrômetro de infravermelho com transformada de Fourier (Nicolet 380). Os espectros foram adquiridos utilizando-se uma resolução de $2 \mathrm{~cm}^{-1}, 32$ repetições e intervalo espectral entre $4000-900 \mathrm{~cm}^{-1}$. Comparando-se todas as linhagens celulares, diferenças com relação às algumas bandas de absorção foram identificadas: $1084 \mathrm{~cm}^{-1}$ (açúcar do DNA sugar e moléculas de $P O_{2}$ ), $1236 \mathrm{~cm}^{-1}$ (ligações fosfodiésteres), $1540 \mathrm{~cm}^{-1}$ (estiramento da Amide II), $2851 \mathrm{~cm}^{-1}$ e $2921 \mathrm{~cm}^{-1}$ (estiramento do $\mathrm{CH}_{2}$ ). Alguns grupos revelaram diferenças nas bandas de absorção referentes ao estiramento das moléculas de $C-C$ and $C-O\left(967 \mathrm{~cm}^{-1}\right)$, configuração $\beta$ da Amida I e estrutura $\alpha$-hélice $\left(1650 \mathrm{~cm}^{-1}\right.$ e $1645 \mathrm{~cm}^{-1}$, respectivamente), permitindo a caracterização destas doenças de forma eficiente por meio da área das bandas de absorção e deslocamento dos picos das mesmas. Através deste trabalho foi possível verificar o potencial de aplicação da espectroscopia por FTIR em estudos de base, visando a caracterização de células do ponto de vista bioquímico, buscando compreender quais fatores biológicos estão relacionados com as diferenças espectrais verificadas e, com isso, fornecer informações qualitativas referentes à ligações químicas relacionadas a determinados biomarcadores existentes em cada amostra biológica. Analisando-se as áreas referentes a cada banda de absorção identificada, foi possível estudar a variação da quantidade de certas macromoléculas existentes nas células; foram estabelecidas hipóteses baseadas nas diferenças encontradas com relação às moléculas de DNA, RNA, proteínas e lipídeos. Tais hipóteses foram associadas a particularidades bioquímicas de determinados grupos de doenças, tais como a hiperexpressão de genes e proteínas, a qual foi relacionada com o aumento da área de 
bandas de absorção referentes à uma determinada macromolécula. Outro ponto abordado foi a análise das razões entre as áreas de diversas bandas de absorção. A partir desta avaliação, foi possível definir bandas referentes a biomarcadores chaves na diferenciação celular. Foram comparadas as razões comumente utilizadas na literatura assim como avaliadas novas combinações, visando uma diferenciação mais eficiente. As novas razões obtidas foram: (i) $1053 \mathrm{~cm}^{-1}$ e $1084 \mathrm{~cm}^{-1}$; (ii) $1540 \mathrm{~cm}^{-1}$ e $10840 \mathrm{~cm}^{-1}$; (iii) $1650 \mathrm{~cm}^{-1}$ e $1084 \mathrm{~cm}^{-1}$; (iv) $1395 \mathrm{~cm}^{-1}$ e $1053 \mathrm{~cm}^{-1}$; (v) $1453 \mathrm{~cm}^{-1}$ e $1053 \mathrm{~cm}^{-1}$; (vi) $1084 \mathrm{~cm}^{-1}$ e $1646 \mathrm{~cm}^{-1}$; (vii) $1084 \mathrm{~cm}^{-1}$ e $2851 \mathrm{~cm}^{-1}$ e, por fim, (viii) $1053 \mathrm{~cm}^{-1}$ e $3060 \mathrm{~cm}^{-1}$. Através das razões de tais bandas de absorção, referentes às proteínas, lipídeos, DNA e RNA, foi possível diferenciar não somente as linhagens celulares pertencentes à um mesmo grupo patológico e sim, adquirir valores distintos para cada uma das oito linhagens estudas. Avanços relacionados à detecção de alterações bioquímicas em células e tecidos podem ocorrer com o emprego de novos procedimentos matemáticos para análise dos dados e desenvolvimento de novas tecnologias através das quais seja possível detectar bandas as quais possuem absorbância fraca e determinação da posição das mesmas com maior acurácia. O deslocamento dos picos, alterações relacionadas à largura das bandas e variações relativas às razões de diversos componentes biológicos podem conter uma informação importante com relação aos bio marcadores envolvidos em diferentes tipos de doenças. Estes biomarcadores detectados através da espectroscopia com FTIR podem ser utilizados na diferenciação e classificação de células neoplásicas e sadias assim como levar a avanços relacionados ao desenvolvimento de protocolos clínicos.

Palavras-chave: espectroscopia, FTIR, câncer, neoplásicas, células 


\section{Abstract}

The molecular mechanisms and changes leading to the development and progression of cancers are extremely complex. FTIR spectroscopy can detect biochemical features of biological materials, enabling the important characterization and differentiation of cells. By looking at the individual absorption bands, it is possible to spot similarities and differences between the cells, which help to understand the changes observed in the same disease cell line group or between healthy and diseases cells. In this work we characterized four sets of neoplastic cells with FTIR spectroscopy. Each cell set was composed of two cell lines: the first one was a set composed by murine melanoma (B16F10) and human melanoma (C8161), the second one was colorectal adenocarcinoma (HT-29), and adenocarcinoma of the cervix (HeLa), the third one two human breast cancers cell lines (SKBr3 cells and MCF-7), and the last one was human leukemia cell line (JURKAT) and peripheral blood mononuclear cell (PBMC). All cell lines were purchased from American Type Culture Collection (ATCC, Manassas, VA, USA). The biochemical analysis was conducted through Fourier transform infrared spectroscopy (Nicolet 380). The spectra were acquired with $2 \mathrm{~cm}^{-1}$ resolution, 32 scans and spectral range between $4000-900 \mathrm{~cm}^{-1}$. Comparing all cell lines, differences in the following absorption bands were identified: $1084 \mathrm{~cm}^{-1}$ (DNA sugar and $P O_{2}$ ), $1236 \mathrm{~cm}^{-1}$ (phosphodiester bonds), $1540 \mathrm{~cm}^{-1}$ (amide II stretching), $2851 \mathrm{~cm}^{-1}$, and $2921 \mathrm{~cm}^{-1}$ ( $\mathrm{CH}_{2}$ stretching). Some groups revealed differences in the absorption bands related to $C-C$ and $C-O$ stretching $\left(967 \mathrm{~cm}^{-1}\right)$, amide I beta sheet and alpha helix structure $\left(1650 \mathrm{~cm}^{-1}\right.$ and $1742 \mathrm{~cm}^{-1}$, respectively), allowing the characterization of these diseases, differentiating them efficiently through the area and peaks displacement of the absorption bands. Through this work it was possible to verify the FTIR spectroscopy potential for application on basic studies, aiming cells characterization from the biochemical point of view, trying to understand which biological factors are related to each spectral differences observed, and provide qualitative information concerning the chemical bonds associated with certain biomarkers in each biological sample. The study of the variation in the amount of certain macromolecules present in cells it was possible to analyse the absorption band areas for each identified band. Hypothesis were established based on assumptions with regard to differences related with molecules as DNA, RNA, proteins and lipids. The hypothesis were associated with biochemical characteristics of certain diseases groups such as genes and proteins hyper expression, which were related to the increase in area of the absorption bands related to each particular macromolecule. The ratio analysis between the areas of different absorption bands was another point discussed. By this analysis it was possible to define biomarkers key bands in cell differentiation. The ratios commonly used in the literature were compared and new combinations were evaluated, aiming more efficient differentiation. The new ratios defined were (i) $1053 \mathrm{~cm}^{-1}$ and $1084 \mathrm{~cm}^{-1}$; (ii) $1540 \mathrm{~cm}^{-1}$ and 
$10840 \mathrm{~cm}^{-1}$; (iii) $1650 \mathrm{~cm}^{-1}$ and $1084 \mathrm{~cm}^{-1}$; (iv) $1395 \mathrm{~cm}^{-1}$ and $1053 \mathrm{~cm}^{-1}$; (v) $1453 \mathrm{~cm}^{-1}$ and $1053 \mathrm{~cm}^{-1}$; (vi) $1084 \mathrm{~cm}^{-1}$ and $1646 \mathrm{~cm}^{-1}$; (vii) $1084 \mathrm{~cm}^{-1}$ and $2851 \mathrm{~cm}^{-1}$ and, finally, (viii) $1053 \mathrm{~cm}^{-1}$ and $3060 \mathrm{~cm}^{-1}$. Through these ratios, related to proteins, lipids, DNA and RNA it was possible to differentiate the cell lines not only belonging to the same pathology, but from every each other cell line. Advances related to the detection of biochemical alterations in cells and tissues will occur with the employment of new mathematical procedures for data analysis and the development of new technologies that will enable detection of weak and broad absorption bands with better accuracy. Peak displacement, alterations related to band width, and variations in the relative ratios of the main biological compounds, may carry important information with respect to biomarkers involved with different disease types. These biomarkers, detected by FTIR spectroscopy, will be used to differentiate and classify neoplastic and healthy cells as well as to lead to advances related to the development of clinical protocols.

Keywords: spectroscopy, FTIR, cancer, neoplastic, cell 


\section{Agradecimentos}

Primeiramente, devo agradecer à minha família, pois sem o seu apoio eu jamais chegaria onde cheguei. Em especial agradeço a minha mãe Eliane, uma guerreira incansável, vencedora de batalhas incríveis por toda sua dedicação. Ao meu pai Fernando, responsável pelo "Método Mostaço" de encarar a vida, através do qual me guio e me inspiro: OBJETIVO, FOCO e TRABALHO...com isso, vou realizando meus sonhos, um a um. Ao meu grande amor, Luiz, pessoa incrível que me completa e me inspira, cuja companhia é primordial em cada conquista.

Gostaria de agradecer também ao meu irmão Guilherme, à minha madrinha, Mariângela, ao meu padrinho Luiz Carlos, ao meu avô Erich e à minha avó Lélia, que com certeza estaria aqui curtindo este momento. Não posso esquecer de agradecer também à minha "nova" família: Dirce, Pedro, Branca, Giulia e Giovanna.

Agradeço ao professor Luciano Bachmann pela orientação e amizade, discussões e conclusões sobre os mais diversos assuntos, tornando esta jornada mais divertida e interessante...e é claro, agradeço também por compreender que às vezes é melhor permitir que eu freqüente o "lab.piscina" !

Ao professor Iouri Borissevitch por toda sua dedicação e orientação nas diversas disciplinas e no laboratório...sendo um mestre que me guiou nos primeiros passos dentro da Ciência.

Ao laboratório de Fotobiofísica pelo suporte, amizade e apoio em todos os momentos. Neste ponto algumas pessoas devem ser citadas: o professor Amando S. Ito, que com seu bom humor e paciência, muito contribuiu com o meu crescimento dentro da Física; ao amigo Fábio A. Schaberle, pelo apoio e paciência ao longo dos meus primeiros trabalhos dentro da pesquisa; às minhas "escravinhas" e amigas, Marina R. Batistituti e Laís P. Martins; ao meu "irmão mais velho", Moisés Santos; aos amigos de laboratório, churrascos e congressos, Fabrício Lima, Leandro Fairbanks, Gustavo G. Parra, Luciana S. Murakami e Cássia A. Marquezin, meus sinceros agradecimentos pela amizade e apoio.

À secretária do Departamento de Física e Matemática, Nilza M. L. Marino, por toda a ajuda prestada.

Ao professor Auro Nomizo, pela colaboração.

Aos amigos "caipiras", Alexandre C. Bruno, Andréia C. Galina, Eduardo I. Ito, Gustavo Tukamoto, Hermes A. S. Kamimura, Hugo V. Toledo, Marcos Vinícius N. Nakandakari, Maristela A. Gomes, Melina H. de Araújo, Rafael C. Araujo,Rodrigo Sato, Rodrigo M. N. Tanaka, Tadeu T. A. Kubo, Tiago R. Giacometti, por todos os momentos vividos ao longo dos últimos anos.

Aos amigos da "capitar", Christiane Castroviejo, Maria Isabel V. Orselli, Renata Beatriz F. Camargo, André Luis Suaide, Tomas Hirayama, Amanda V. Gomes e Fabiana Regina de S. Irrera, Vanessa Lima e Fernando Cerboncini, que apesar da distância, 
sempre estiveram presentes de alguma forma.

Aos amigos "do esporte", Leandro Arruda, Douglas Ramachotte, Sérgio Buonarotti, Luiz Ruffino, Ronaldo Cesquim, Ailton M. Watanabe e Mirko Alva pela amizade e bom humor, indispensáveis para que a minha sanidade fosse mantida ao longo desta trajetória.

De uma forma geral, gostaria de expressar meus sinceros agradecimentos a todas as pessoas que de alguma forma contribuíram para que este trabalho se tornasse uma realidade; não estarem citadas aqui, não significa que foram esquecidas.

Por fim, agradeço à Capes e ao CNPq pelo suporte financeiro dado à este projeto. 


\section{Sumário}

Sumário $\quad$ i

Lista de Figuras $\quad$ iii

Lista de Tabelas $\quad$ ix

1 Introdução 1

1.1 Teoria Eletromagnética Clássica . . . . . . . . . . . . . . . 2

1.2 Teoria Eletromagnética Quântica . . . . . . . . . . . . . . . 5

1.3 Teoria Clássica e Quântica da Espectroscopia Vibracional e Rotacional . 7

1.4 Espectroscopia na Região do Infravermelho . . . . . . . . . . . . . . . . . 9

1.5 Espectrômetro de Infravermelho com Transformada de Fourier . . . . . . 11

1.5.1 Interferômetro de Michelson . . . . . . . . . . . . . . . . . . . . . 11

1.5.2 Vantagens dos Espectrômetros com Transformada de Fourier . . . 15

1.6 A célula e suas Macromoléculas . . . . . . . . . . . . . . . . . 16

1.6.1 Açúcares e Polissacarídeos . . . . . . . . . . . . . . . . . . . . 18

1.6.2 Ácidos Graxos, Gorduras, Lipídeos e Membranas . . . . . . . . . 19

1.6.3 Aminoácidos e Proteínas . . . . . . . . . . . . . . . . . . . . 21

1.6.4 Nucleotídeos e Ácidos Nucléicos . . . . . . . . . . . . . . . . . . . 22

1.7 A Bioquímica da Célula Neoplásica . . . . . . . . . . . . . . . 25

2 Motivação e Objetivos 27

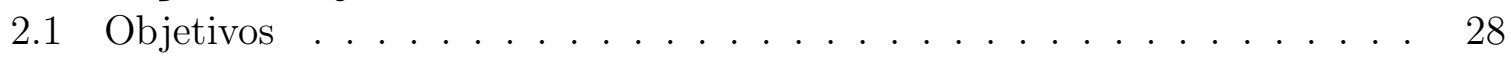

2.1.1 Objetivos Específicos . . . . . . . . . . . . 28

3 Materiais e Metodologia $\quad 29$

3.1 Objetos de Estudo: Células . . . . . . . . . . . . . . . . . . . . . 29

3.1 .1 Linhagens Celulares . . . . . . . . . . . . . . . . . . . . 30

3.1 .2 Cultura Celular . . . . . . . . . . . . . . . . 32

3.2 Espectroscopia por FTIR . . . . . . . . . . . . . . . . . . . 34

3.2.1 Teste do Sinal vs. Ruído do Ambiente . . . . . . . . . . . . . . 34

3.2 .2 Janela de $C a F_{2} \ldots \ldots \ldots$. . . . . . . . . . . . . 36

3.2.3 Teste de Sinal dos Meios de Cultura . . . . . . . . . . . . . . . 37

3.3 Análise dos dados . . . . . . . . . . . . . . . . . . . . . . . . . . . 38

4 Resultados e Discussões $\quad 41$

4.1 Melanoma Humano vs. Melanoma Murino . . . . . . . . . . . . . . . . . 44

4.2 Adenocarcinoma de Cérvix vs. Adenocarcinoma de Cólon . . . . . . . . . 53

4.3 Câncer de mama ER+vs. ER- . . . . . . . . . . . . . . . . 61 
4.4 Leucemia Tipo T vs. Linfócitos T . . . . . . . . . . . . . . . . . . . 68

4.5 Estrutura secundária das proteínas . . . . . . . . . . . . . . 76

4.6 Análise de razões . . . . . . . . . . . . . . . . . . . . . . 80

5 Conclusões $\quad 89$

$\begin{array}{ll}\text { Referências Bibliográficas } & 91\end{array}$

$\begin{array}{lr}\text { Glossário } & 97\end{array}$ 


\section{Lista de Figuras}

1.1 Esquema do espectro eletromagnético, através do qual é possível observar a região correspondente à radiação infravermelha, a qual possui uma freqüência da ordem de $10^{14} \mathrm{~Hz}$, ou comprimento de onda de aproximada-

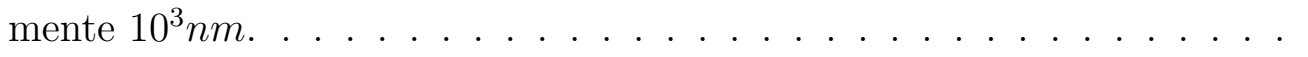

1.2 O espectro eletromagnético é constituído por duas componentes simétricas, as quais se propagam através de uma onda senoidal. A radiação eletromagnética é representada por dois campos mutualmente perpendiculares: o campo elétrico $(\vec{E})$ e o campo magnético $(\vec{B})$. . . . . . . . . . . .

1.3 Ilustração do momento de dipolo, $\vec{p}$ de uma molécula de dióxido de carbono, onde " $O$ " representa um átomo de oxigênio e " $C$ ", um átomo de carbono. . . . . . . . . . . . . . . . . .

1.4 Esquema ilustrativo da energia de um oscilador harmônico (azul) e anarmônico (vermelho). As linhas horizontais representam os níveis energéticos dos estados vibracionais. Imagem: adaptada de http://www . unb.br/iq/kleber/CursosVirtuais/QQ/aula-10 . . . . . . . .

1.5 Diagrama esquemático de um espectrômetro com transformada de Fourier, com um interferômetro de Michelson clássico. Imagem: adaptada de Johnston, S., Fourier transform infrared: a constantly evolving technology, 1991. 12

1.6 Diagrama óptico de um espectrômetro comercial, sendo o arranjo do interferômetro de Michelson clássico a base deste modelo. Q, representa a fonte de radiação; DV, é o divisor de feixes; SM, é o scanner mecânico; A, é a abertura; D, é o detector e $D_{L}$, o detector do laser; E1-E4 são espelhos de foco e E, espelhos planos. Imagem: adaptada de Johnston, S., Fourier transform infrared: a constantly evolving technology, 1991. . . . . . . . .

1.7 Mudança do caminho óptico através da rotação de um par de espelhos, onde $\mathrm{DF}$ é o divisor de feixes e F, o espelho fixo. Imagem: adaptada de Johnston, S., Fourier transform infrared: a constantly evolving technology,

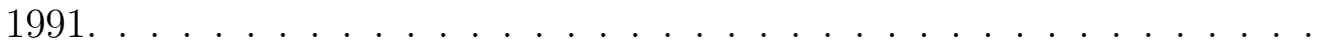

1.8 Esquema ilustrando as quatro famílias principais de moléculas orgânicas presentes nas células. No quadro são apresentadas as unidades básicas e as respectivas macromoléculas, as quais são compostas por tais unidades. Imagem: adaptada de Alberts, B., Molecular biology of the cell, 2002. . .

1.9 Estrutura química da molécula de glicogênio, polissacarídeo composto por unidades de glicose, as quais atuam como reservas de energia de longo prazo. Imagem: adaptada de Alberts, B., Molecular biology of the cell, 2002 
1.10 Esquema simplificado representativo da membrana celular, através do qual é possível notar a camada bilipídica, tendo os ácidos graxos como unidades que compõem a maior parte da mesma. . . . . . . . . . . . . . . .

1.11 Esquema das estruturas das proteínas. Em (a) é apresentada a estrutura primária (formada por uma seqüência de aminoácido); (b) estrutura secundária, classificada em configuração beta ou alfa hélice; (c) estrutura terciária, a qual é responsável pelo controle da função básica da proteína; (d) estrutura quaternária, resultante da interação de mais de uma molécula de proteína. Imagem: adaptada de www.biomol.org . . .

1.12 Estrutura química dos nucleotídeos: a citosina, uracila e timina são denominadas pirimidinas; a guanina e a adenina são denominadas purinas. Imagem: adaptada de Alberts, B., Molecular biology of the cell, 2002. . .

1.13 Os filamentos do DNA e do RNA são compostos por açúcares e pelas porções de fosfato dos nucleotídeos; ligadas por pontes de hidrogênio. O par composto pela adenina $(\mathrm{A})$ e timina $(\mathrm{T})$ - ou uracila $(\mathrm{U})$, no caso do RNA - é formado através de duas pontes de hidrogênio; os pares compostos pela guanina $(G)$ e citosina $(C)$ são ligados através de três pontes de hidrogênio. Imagem: adaptada de Alberts, B., Molecular biology of the cell, 2002. . . . . . . . . . . . . . . .

1.14 Um conjunto de células compõe tecidos e órgãos; células normais possuem seu ciclo celular bem definido, porém caso as células possuam alguma mutação que altere seu ciclo, esta faz com que as mesmas se reproduzam de maneira errônea e desordenada, dando origem a um câncer, ou seja, à multiplicação desordenada de células que invadem tecidos e órgãos adjacentes. Imagem: adaptada de www.ache.com.br/_img/infografico.jpg

3.1 Esquema ilustrativo de parte do procedimento adotado nas culturas celulares. As células foram mantidas em garrafas de cultura; uma vez atingida a confluência, as mesmas foram retiradas das garrafas (através da utilização da tripsina, no caso das linhagens aderentes), mescladas a uma solução de TURK para que as mesmas fossem contadas num hemocitômetro. 33

3.2 Gradiente de densidade formado através da utilização do Ficoll, para separação dos componentes do sangue. As PBMC formam um anel situado entre o plasma sangüíneo e o Ficoll. . . . . . . . . . . . . . . . . . .

3.3 Teste de verificação dos efeitos de alterações na resolução e passo de aquisição dos dados, assim como variação do tempo de imersão da amostra no fluxo de ar seco. A banda de absorção das moléculas de $\mathrm{CO}_{2}$ está situada na região de $2400 \mathrm{~cm}^{-1}$, ao passo que as bandas referentes à absorção das moléculas de água estão localizadas nas regiões próximas a $1600 \mathrm{~cm}^{-1}$ e $3800 \mathrm{~cm}^{-1}$. Na figura 3.3(a) são apresentados os espectros adquiridos com resolução 32 e de passo $2 \mathrm{~cm}^{-1}$; na figura $3.3(\mathrm{~b})$, são apresentados os espectros com resolução 32 e passo $4 \mathrm{~cm}^{-1}$; na figura $3.3(\mathrm{c})$ e $3.3(\mathrm{~d})$ observamos os espectros adquiridos com resolução de 32 e passo $6 \mathrm{~cm}^{-1}$, resolução 64 e passo $2 \mathrm{~cm}^{-1}$, respectivamente. . . . . . . . . . . . . . .

3.4 Espectro de absorção da janela de $\mathrm{CaF}_{2}$ utilizada neste trabalho; sendo a mesma transparente na região espectral de interesse, situada entre $950 \mathrm{~cm}^{-1}$ e $4000 \mathrm{~cm}^{-1} \ldots \ldots \ldots \ldots \ldots \ldots$ 
3.5 Espectros de absorção dos meios de cultura utilizados nas culturas celulares. Tais meios, por se tratarem de compostos químicos complexos, possuem bandas de absorção situadas na região de interesse; porém, observandose o espectro de absorção da solução salina, é possível verificar a ausência de bandas de absorção na região de interesse, confirmando que a mesma pode ser utilizada de maneira satisfatória na lavagem das células, previamente à realização dos experimentos. . . . . . . . . . . . . . . . . .

4.1 Espectro de absorção típico das amostras estudadas; neste caso, é apresentado um espectro de melanoma. Para facilitar a caracterização das bandas identificadas, foi proposta a divisão espectral apresentada, onde a maioria das bandas de absorção referentes ao DNA estão situadas na região de $900-1300 \mathrm{~cm}^{-1}$; as bandas referentes às proteínas encontram-se na região $1450-1700 \mathrm{~cm}^{-1}$ e às bandas referentes aos lipídeos situam-se em torno de $2800-3100 \mathrm{~cm}^{-1}$. . . . . . . . . . . . . .

4.2 Espectros de absorção médios obtidos para cada linhagem estudada. Todos os espectros são apresentados normalizados pela área da banda de absorção localizada na região de $1238 \mathrm{~cm}^{-1}$, sendo esta associada ao estiramento $(\nu)$ assimétrico da molécula de $\mathrm{PO}_{2}$, contida nas ligações fosfodiéster do DNA. Na figura 4.2(a) são apresentados os espectros de absorção referentes aos melanomas humano e murino; na figura 4.2(b) são apresentados os espectros referentes aos adenocarcinomas de cérvix e cólon; na figura 4.2(c) são apresentados os espectros das linhagens de cânceres de mama e na figura 4.2(d), observamos os espectros de absorção dos linfócitos $\mathrm{T}$ e da linhagem de leucemia tipo $\mathrm{T}$ humana. . . . . . . . . . .

4.3 Esquema simplificado da pele humana. As principais camadas que compõem a mesma são a epiderme, derme e o tecido subcutâneo. Os cânceres de pele, em geral, se desenvolvem na região da epiderme. Imagem: http: //www.wpclipart.com/medical . . . . . . . . . . . . . . .

4.4 Derivadas de segunda ordem do espectro de absorção (figura 4.2(a) de ambas as linhagens de melanomas; são apresentados os valores do número de onda das bandas de absorção cujos deslocamentos dos picos, de uma linhagem com relação à outra, foram identificados. Os picos de absorção da linhagem C8161 foram adotados como referência. . . . . . . . . . . . .

4.5 Esquema de um cromossomo, em cujas extremidades localizam-se os telômeros. Estes constituem uma seqüência chave a qual indica o início e término da informação genética durante a replicação do DNA, sendo uma seqüência de guanina (G) e citosina (C). Imagem: adaptada de http://www. biochem. med.umich.edu . . . . . . . . . . . . . . . . .

4.6 Esquema ilustrativo da compactação do DNA: a dupla hélice (A) é enrolada em histonas (B); estes são denominados nucleossomos, os quais são agrupados formando uma fibra através da qual é formada a cromatina e, conseqüentemente os cromossomos (C). Imagem: adaptada de http://www . biochem . med.umich.edu ................ 
4.7 Esquema ilustrando a cascata metabólica da via sinalizadora Ras-RafMAPK: o fator de crescimento epidérmico (EGF) ativa o receptor do fator de crescimento epidérmico (EGFR), que por sua vez estimula a atividade de receptores catalíticos, ativando diversas proteínas, entre elas a proteína Ras. Esta está relacionada com o receptor catalítico tirosina-quinase e é codificada pelo gene Raf. A Ras é ativada quando combinada com GTP, podendo se ligar a outras proteínas que estimulam a via sinalizadora MAPK, dirigindo a proliferação e diferenciação celular. Imagem: adaptada de http://www.cellsignal.com . . . . . . . . . . . .

4.8 Ilustração dos órgãos reprodutores femininos; vale destacar a localização do cérvix (ou colo do útero), região a qual é composta basicamente por células epiteliais glandulares e escamosas. Imagem: http://www . wpclipart. com/medical . . . . . . . . . . . . . . . .

4.9 Progressão dos tumores de cólon: os estágios 0 e 1 correspondem à lesão de cripta simples; os estágios 2 e 3 , são caracterizados por pequenos tumores benignos (denominados pólipos adenomatosos); estes tumores, caso não sejam tratados, crescem até atingir o nível de cânceres malignos (estágio 4 - carcinomas). Imagem: http://cancer.med.upenn.edu . . . . . . . .

4.10 Derivadas de segunda ordem do espectro de absorção das linhagens de adenocarcinomas de cérvix (HeLa) e de cólon (HT-29); são apresentados os valores do número de onda das bandas de absorção cujos deslocamentos dos picos, de uma linhagem com relação à outra, foram identificados. Os picos de absorção da linhagem HeLa foram adotados como referência. . .

4.11 Ciclo biológico dos HPVs: partículas virais penetram nas células da camada mais profunda, a qual é composta pelas células menos diferenciadas do epitélio escamoso. O vírus penetra na célula através da interação das proteínas do capsídeo com receptores específicos da superfície celular. Após penetrar na célula, o vírus expõe seu DNA a ação de enzimas nucleares, as quais favorecem a expressão dos genes virais. Imagem adaptada de http://www.thebody.com . . . . . . . . . . . . . . . .

4.12 Esquema simplificado da mama adulta humana. A mama é composta por ductos lactíferos epiteliais, os quais terminam em alvéolos secretores, imersos em tecido fibrosos e gordura. Os carcinomas de mama, em geral, iniciam seu desenvolvimento no interior dos ductos. Imagem: http:// www. wpclipart.com/medical . . . . . . . . . . . . .

4.13 Derivadas de segunda ordem do espectro de absorção de ambas as linhagens de câncer de mama; são apresentados os valores do número de onda das bandas de absorção cujos deslocamentos dos picos, de uma linhagem com relação à outra, foram identificados. Os picos de absorção da linhagem SKBr3 foram adotados como referência. . . . . . . . . . . . . . .

4.14 Regulação do crescimento do câncer de mama devido a hormônios e fatores de crescimento. E=estrogênio; $\mathrm{Pg}=$ progesterona; $\mathrm{Pr}=$ prolactina; $\mathrm{I}=$ insulina; IGF's=Fatores de crescimento do tipo insulina; $\mathrm{EGF}=$ fatores de crescimento epidérmicos; TGF- $\alpha=$ fator de crescimento transformante alfa; $T_{3,4}=$ hormônios da tireóide; TGF- $\beta=$ fator de crescimento transformante beta. Imagem: adaptada de R.C. Bast, Cancer and Medicine, 2000. 
4.15 As células tronco dividem-se e seguem caminhos de desenvolvimento distintas, que resultam em diferentes tipos de células sangüineas e plaquetas. Neste diagrama, várias formas intermediárias foram omitidas. Imagem: http://www.wpclipart.com/medical/index.html . . . . . . . .

4.16 Derivadas de segunda ordem do espectro de absorção das amostras de leucemia e células mononucleares de sangue periférico humano; são apresentados os valores do número de onda das bandas de absorção cujos deslocamentos dos picos, de uma linhagem com relação à outra, foram identificados. Os picos de absorção da linhagem PBMC foram adotados como referência. . . . . . . . . . . . . . . . . . . .

4.17 Derivada de segunda ordem da região do espectro de absorção referente à amida I, uma vez que esta molécula é sensível à conformação das proteínas celulares. As bandas localizadas em $1646 \mathrm{~cm}^{-1}$ e $1652 \mathrm{~cm}^{-1}$ estão associadas à conjugação beta e estrutura alfa-hélice, respectivamente. . . . . . .

4.18 Valores médios das razões comumente adotadas na literatura, calculadas para cada linhagem celular estudada neste trabalho. Tais razões relacionam as principais macromoléculas presentes nas amostras biológicas: as proteínas, lipídeos, DNA e RNA. . . . . . . . . . . . .

4.19 Valores médios das razões definidas com o objetivo de diferenciar todas as linhagens celulares estudadas neste trabalho. Tais razões relacionam as principais macromoléculas presentes nas amostras biológicas: as proteínas, lipídeos e DNA . . . . . . . . . . . . . . . . . . . 


\section{Lista de Tabelas}

4.1 Principais bandas de absorção referentes às linhagens celulares de melanoma humano (C8161) e melanoma murino B16F10, cujas associações químicas e biológicas foram obtidas a partir de diversos trabalhos $[2,41$, $3,4,46,48,49]$. Os símbolos empregados na coluna referente à associação química estão relacionados aos modos vibracionais de estiramento $(\nu)$, modo vibracional de tesoura $(\varsigma)$, modo vibracional de flexão $(\delta)$, movimentos simétricos (sim.) e assimétricos (assim.). . . . . . . . . .

4.2 Valor médio da área das bandas de absorção, onde C8161 corresponde a linhagem de melanoma humano e B16F10 corresponde a linhagem de melanoma murino. As bandas as quais apresentam um valor de $p$ menor que 0, 05 (através do teste $t$ de Student), foram consideradas distintas. A posição do pico de absorção é exibida considerando-se a linhagem C8161 como referência. . . . . . . . . . . . . . . . . . .

4.3 Principais bandas de absorção referentes às linhagens celulares de adenocarcinoma de cérvix (HeLa) e adenocarcinoma de cólon HT-29, cujas associações químicas e biológicas foram obtidas a partir de diversos trabalhos $[2,41,3,4,46,48,49]$. Os símbolos empregados na coluna referente à associação química estão relacionados aos modos vibracionais de estiramento $(\nu)$, modo vibracional de tesoura $(\varsigma)$, modo vibracional de flexão $(\delta)$, movimentos simétricos (sim.) e assimétricos (assim.). . . . . . . .

4.4 Valor médio da área das bandas de absorção, onde HeLa corresponde à linhagem de adenocarcinoma de cérvix e HT-29 corresponde à linhagem de adenocarcinoma de cólon. As bandas as quais apresentam um valor de $p$ menor que 0,05 (através do teste $\mathrm{t}$ de Student), foram consideradas distintas. A posição do pico de absorção é exibida considerando-se a linhagem HeLa como referência. . . . . . . . . . . . . . . . .

4.5 Principais bandas de absorção referentes às linhagens celulares de câncer de mama humano, com receptores de estrogênio positivo (MCF-7) e receptores de estrogênio negativo $\mathrm{SKBr}$, cujas associações químicas e biológicas foram obtidas a partir de diversos trabalhos [2, 41, 3, 4, 46, 48, 49]. Os símbolos empregados na coluna referente à associação química estão relacionados aos modos vibracionais de estiramento $(\nu)$, modo vibracional de tesoura $(\varsigma)$, modo vibracional de flexão $(\delta)$, movimentos simétricos $(\mathrm{sim}$. e assimétricos (assim.). . . . . . . . . . . . . . . 
4.6 Valor médio da área das bandas de absorção, onde MCF-7 corresponde à linhagem de câncer de mama com receptores de estrogênio positivos e $\mathrm{SKBr} 3$ corresponde à linhagem com receptores de estrogênio negativos. As bandas as quais apresentam um valor de $p$ menor que 0,05 (através do teste $\mathrm{t}$ de Student), foram consideradas distintas. A posição do pico de absorção é exibida considerando-se a linhagem MCF-7 como referência.

4.7 Principais bandas de absorção referentes às linhagens celulares de leucemia humana do tipo T (JURKAT) e células mononucleares de sangue periférico humano PBMC, cujas associações químicas e biológicas foram obtidas a partir de diversos trabalhos [2, 41, 3, 4, 46, 48, 49]. Os símbolos empregados na coluna referente à associação química estão relacionados aos modos vibracionais de estiramento $(\nu)$, modo vibracional de tesoura $(\varsigma)$, modo vibracional de flexão $(\delta)$, movimentos simétricos (sim.) e assimétricos

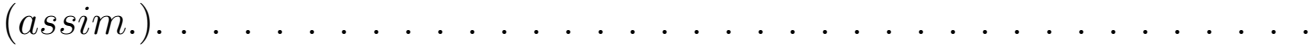

4.8 Valor médio da área das bandas de absorção, onde JURKAT corresponde à linhagem celular de leucemia humana do tipo T e PBMC, corresponde às células mononucleares de sangue periférico humano. As bandas as quais apresentam um valor de $p$ menor que 0,05 (obtidos através do teste t de Student), foram consideradas distintas. A posição do pico de absorção é exibida considerando-se a linhagem JURKAT como referência. . . . . . . . .

4.9 Valores médios das áreas das bandas de absorção, relacionadas aos modos vibracionais dos lipídeos das diversas linhagens de células neoplásicas, juntamente com os valores obtidos para as células sadias PBMC.Os valores apresentados na coluna referente aos picos de absorção, são valores correspondentes à região aproximada a qual as bandas de absorção estão localizadas no espectro. . . . . . . . . . . . . . . .

4.10 Valores médios das áreas e picos das bandas de absorção da região da amida I, referentes às linhagens celulares: C8161, melanoma humano; B16F10, melanoma murino; HT-29, adenocarcinoma de cólon. HeLa, adenocarcinoma de cérvix; SKBr3, câncer de mama (ER-);MCF-7, câncer de mama (ER+); JURKAT, leucemia do tipo T e PBMC, células mononucleares de sangue periférico humano. . . . . . . . . . . . . . . . .

4.11 Valores de $p$, obtidos através do teste $\mathrm{t}$ de Student, comparando-se todas as linhagens celulares estudadas neste trabalho; os valores de $p$ inferiores a 0,05 indicam que o par analisado pôde ser diferenciado através da razão entre bandas de absorção considerada. Considerando-se a diagonal principal, os valores situados abaixo da mesma são referentes à razão entre as bandas situadas na região de $1453 \mathrm{~cm}^{-1}$ e $1053 \mathrm{~cm}^{-1}$; os valores situados acima são referentes à razão entre as bandas situadas na região de $1084 \mathrm{~cm}^{-1}$ e $1646 \mathrm{~cm}^{-1}$.

4.12 Valores de $p$, obtidos através do teste t de Student, comparando-se todas as linhagens celulares estudadas neste trabalho; os valores de $p$ inferiores a 0,05 indicam que o par analisado pôde ser diferenciado através da razão entre bandas de absorção considerada. Considerando-se a diagonal principal, os valores situados abaixo da mesma são referentes à razão entre as bandas situadas na região de $1084 \mathrm{~cm}^{-1}$ e $2851 \mathrm{~cm}^{-1}$; os valores situados acima são referentes à razão entre as bandas situadas na região de $1053 \mathrm{~cm}^{-1}$ e $3060 \mathrm{~cm}^{-1}$. . . . . . . . . . . . . . . . 
4.13 Valores de $p$, obtidos através do teste $\mathrm{t}$ de Student, comparando-se todas as linhagens celulares estudadas neste trabalho; os valores de $p$ inferiores a 0,05 indicam que o par analisado pôde ser diferenciado através da razão entre bandas de absorção considerada. Considerando-se a diagonal principal, os valores situados abaixo da mesma são referentes à razão entre as bandas situadas na região de $1053 \mathrm{~cm}^{-1}$ e $1084 \mathrm{~cm}^{-1}$; os valores situados acima são referentes à razão entre as bandas situadas na região de

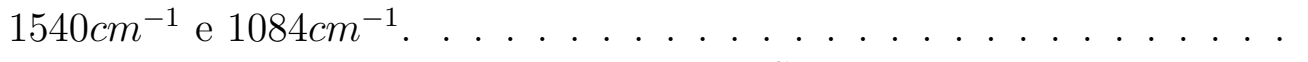

4.14 Valores de $p$, obtidos através do teste $\mathrm{t}$ de Student, comparando-se todas as linhagens celulares estudadas neste trabalho; os valores de $p$ inferiores a 0,05 indicam que o par analisado pôde ser diferenciado através da razão entre bandas de absorção considerada. Considerando-se a diagonal principal, os valores situados abaixo da mesma são referentes à razão entre as bandas situadas na região de $1650 \mathrm{~cm}^{-1}$ e $1084 \mathrm{~cm}^{-1}$; os valores situados acima são referentes à razão entre as bandas situadas na região de $1395 \mathrm{~cm}^{-1}$ e $1053 \mathrm{~cm}^{-1}$. . . . . . . . . . . . . . . . 88 


\section{Capítulo 1}

\section{Introdução}

Uma das primeiras aplicações da espectroscopia no infravermelho como ferramenta analítica, foi durante o período da Segunda Guerra Mundial [1]. Nesta ocasião, esta técnica foi utilizada no setor de controle de qualidade em algumas indústrias químicas alemãs.

Contudo, sabia-se que os espectros no infravermelho armazenavam uma grande gama de informações sobre a amostra e portanto, apresentavam um elevado potencial para serem empregados nos mais diversos tipos de análises químicas e físicas. Entretanto, até cerca da década de 1970 era praticamente impossível extrair informações quantitativas a partir dos espectros no infravermelho. Devido a este fato, a espectroscopia no infravermelho restringiu-se basicamente a aplicações qualitativas ou para reforçar hipóteses propostas sobre a estrutura química das espécies.

Em meados de 1980, uma série de fatos nas áreas científica e tecnológica contribuíram para a inversão deste quadro. Dentre estes, podemos destacar o desenvolvimento da microeletrônica e a popularização dos computadores, que proporcionaram um significativo avanço nas análises instrumentais, possibilitando a aquisição de maneira fácil e rápida de um grande número de dados de uma mesma amostra, além do desenvolvimento e aperfeiçoamento dos métodos de análises espectroscópicas no infravermelho.

Estas análises, além de fornecerem os resultados de maneira mais rápida, não são destrutivas e invasivas, assim como não geram subprodutos químicos tóxicos. Devido à estas vantagens, a espectroscopia no infravermelho passou a atrair a atenção na Medicina e na Biologia. Dentre as diversas aplicações desta técnica, está a caracterização e identificação de células e tecidos tumorais $[2,3,4,5,6,7]$, a qual é o foco deste trabalho.

Esta dissertação está organizada em 5 capítulos: no primeiro capítulo é feita uma descrição relativa à teoria que envolve a espectroscopia no infravermelho, à instrumentação utilizada, além de apresentar uma visão geral da composição biológica das células. No capítulo 2 são apresentados os objetivos gerais e específicos, além da motivação que nos levou à execução deste trabalho.

No capítulo 3 é descrita a metodologia empregada para a realização dos experimentos; 
é realizada a descrição de cada linhagem celular utilizada, passando pelos protocolos de cultura celular adotados, além dos testes realizados a fim de se definir os parâmetros a serem adotados para as medições dos espectros. Uma breve descrição dos métodos empregados para a análise espectral também é apresentado neste capítulo.

No capítulo 4 são apresentados os resultados e as discussões. Tal capítulo encontrase subdividido de acordo com os conjuntos de linhagens celulares analisadas: o primeiro conjunto é referente às linhagens de melanoma; o segundo, é referente ao adenocarcinoma de cérvix e cólon; no terceiro, apresentamos os resultados referentes às linhagens provenientes do câncer de mama e na quarta subseção, apresentamos os resultados referentes à comparação de células sadias com uma linhagem de células tumorais. Após a apresentação das características das diversas linhagens, temos uma seção especialmente dedicada à discussão das alterações referentes às bandas de absorção das proteínas. Para finalizar este capítulo, é apresentada uma análise relativa às razões entre diversas bandas de absorção, consideradas características de certas macromoléculas celulares; por fim, no capítulo 5 são apresentadas as principais conclusões deste trabalho.

\subsection{Teoria Eletromagnética Clássica}

O ápice da teoria ondulatória da luz coincidiu com a publicação, por James Clerk Maxwell, de uma série de artigos [8]; durante a construção de sua teoria eletromagnética, Maxwell gradativamente foi se convencendo da existência de um hipotético éter eletromagnético. Este éter seria o responsável pela propagação de algo, que Michael Faraday (1846) [9] denominara como sendo radiação; a radiação, nada mais seria que uma vibração das linhas de campo.

Em seu tratado sobre eletricidade e magnetismo, publicado em 1874 [8], Maxwell refere-se a essa radiação, proposta por Faraday, como propagação de ondulações em um meio não condutor. Chega então a deduzir uma fórmula para relacionar propriedades eletromagnéticas, definidas em sua teoria, com a velocidade, $c$, de propagação desses distúrbios eletromagnéticos, chegando então à seguinte expressão,

$$
c=\frac{1}{\sqrt{\mu_{0} \epsilon_{0}}}
$$

na qual $\epsilon_{0}$ representa a permissividade elétrica no vácuo e $\mu_{0}$, a permeabilidade magnética no vácuo.

Como $\epsilon_{0}$ e $\mu_{0}$ são passíveis de determinação laboratorial, Maxwell utilizou-se dos valores dessas propriedades eletromagnéticas (conhecidas na época), para chegar ao valor numérico de $c$.

Maxwell concluiu então, que $c$ era da mesma ordem de grandeza da já determinada velocidade da luz no ar ou no espaço planetário (vácuo) [9]. 
Ao concluir sua teoria, Maxwell tinha plena convicção de que o éter eletromagnético seria o mesmo éter luminífero das teorias óptico-ondulatórias aceitas na época, mas é importante ressaltar que as ondulações eletromagnéticas eram encaradas, na época de Faraday e Maxwell, como hipóteses ainda que descrevessem com propriedade os distúrbios observados em um campo eletromagnético; somente em 1888 (quinze anos após a publicação do tratado de eletromagnetismo de Maxwell), essas "ondulações" foram produzidas e detectadas por Heinrich Hertz [10].

A identidade entre essas ondulações e a luz não era necessária para a conclusão da teoria eletromagnética de Maxwell. Muito pelo contrário, foi com essa hipótese, assumida após a conclusão de estudos relativos ao eletromagnetismo, que Maxwell desenvolveu outra teoria: a teoria eletromagnética da luz, exposta nos quatro últimos capítulos de seu tratado sobre eletromagnetismo. A partir dessa teoria, Maxwell passou em definitivo, a optar pela aceitação da luz como "onda eletromagnética".

As ondas eletromagnéticas no vácuo possuem a mesma velocidade, modificando a sua freqüência de acordo com o meio e, conseqüentemente, seu comprimento de onda. A natureza dos vários tipos de radiação eletromagnética foi interpretada por Maxwell em sua teoria da eletrodinâmica clássica. Nesta teoria, é mostrada que a energia transportada por uma onda eletromagnética é proporcional ao quadrado da amplitude de sua componente elétrica e magnética,

$$
u=\frac{1}{2} \epsilon_{0} E_{0}^{2} \frac{1}{\mu_{0}} B_{0}^{2}
$$

na qual $E_{0}$ é a componente referente ao campo elétrico e $B_{0}$, a componente relativa ao campo magnético.

Diversos experimentos mostram que a interação da radiação eletromagnética com a matéria, depende não somente de sua amplitude (intensidade), mas também do comprimento de onda da mesma [11].

A palavra espectro (do latim "spectrum", que significa fantasma ou aparição) foi usada por Isaac Newton, no século XVII, para descrever a faixa de cores que apareceu em uma experiência, quando a luz do Sol atravessou um prisma de vidro [12].

Atualmente, chama-se espectro eletromagnético a faixa de freqüências e seus respectivos comprimentos de ondas, os quais caracterizam os diversos tipos de ondas eletromagnéticas. De acordo com a mecânica quântica, a energia dos fótons e conseqüentemente os efeitos sobre a matéria, dependem de dois parâmetros: a freqüência dos mesmos (ou comprimento de onda) e o número total de fótons, o qual determina a intensidade da radiação eletromagnética. Considerando-se esses efeitos, é possível separar as ondas eletromagnéticas em várias faixas, caracterizadas pelo comprimento de onda ou pela freqüência, conforme mostrado na figura 1.1 . 


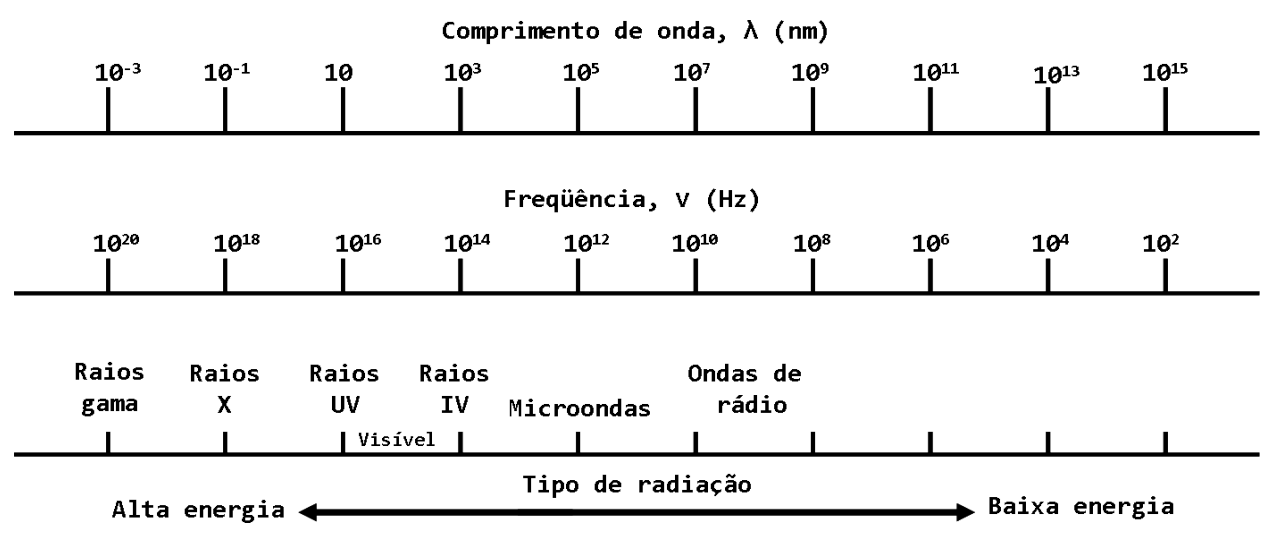

Figura 1.1: Esquema do espectro eletromagnético, através do qual é possível observar a região correspondente à radiação infravermelha, a qual possui uma freqüência da ordem de $10^{14} \mathrm{~Hz}$, ou comprimento de onda de aproximadamente $10^{3} \mathrm{~nm}$.

A radiação eletromagnética é representada por dois campos mutuamente perpendiculares: um elétrico e outro magnético; tais campos oscilam em planos perpendiculares, em fase no vácuo e se propagam através de uma onda senoidal, conforme apresentado na figura 1.2. Os vetores do campo elétrico e magnético são representados por $\vec{E}$ e $\vec{B}$, respectivamente [13].

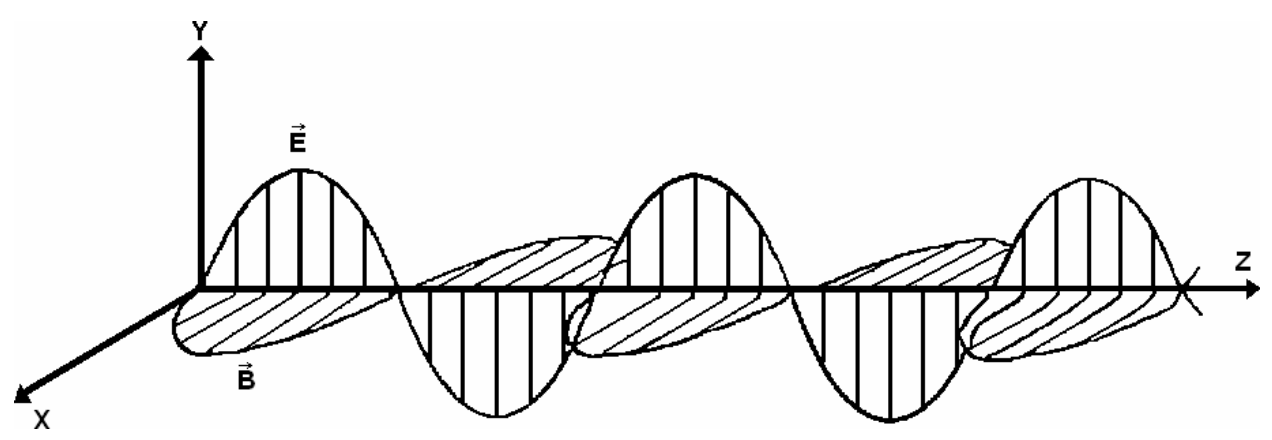

Figura 1.2: O espectro eletromagnético é constituído por duas componentes simétricas, as quais se propagam através de uma onda senoidal. A radiação eletromagnética é representada por dois campos mutualmente perpendiculares: o campo elétrico $(\vec{E})$ e o campo magnético $(\vec{B})$.

A velocidade de propagação de uma onda eletromagnética depende do meio em que a mesma se propaga. Aplicando-se os valores da permissividade elétrica e da permeabilidade magnética no vácuo na equação citada, encontramos o valor $c=2,997925 \times 10^{8} \mathrm{~m} / \mathrm{s}$, que coincide com a velocidade de propagação da luz no vácuo. Outra grande descoberta está relacionada com o fato de que a velocidade de propagação no vácuo é constante para todas as regiões do espectro.

Em qualquer meio homogêneo com índice de refração $n$, a velocidade é determinada pela razão $\frac{c}{n}$. Ao imaginarmos uma onda completa, viajando a uma distância fixa a cada 
ciclo, é possível notar que a velocidade desta onda é o produto do comprimento de onda $(\lambda)$ - ou distância entre picos adjacentes - e da freqüência, $\nu$ - ou número de ciclos por segundo,

$$
c=n \lambda \nu .
$$

O índice de refração, $n$, é a razão da velocidade da radiação eletromagnética no vácuo pela velocidade de propagação da mesma num meio homogêneo. A partir do comprimento de onda de qualquer radiação, a freqüência pode ser obtida em hertz (ciclos por segundo), utilizando-se a equação

$$
\nu=\frac{c}{\lambda} .
$$

Vale à pena citar uma outra unidade usada particularmente na região ótica do espectro (ultravioleta, visível e infravermelho). Esta unidade é o número de onda (expresso em $\mathrm{cm}^{-1}$ ), o qual consiste na quantidade de ondas formadas dentro de um período, $P$. Esta unidade pode ser definida através da relação,

$$
k=\frac{2 \pi \nu}{c}=\frac{2 \pi}{\lambda}
$$

Para descrever a posição das bandas, na espectroscopia de infravermelho é mais conveniente usar o número de onda, $k,\left(1 \mathrm{~cm}^{-1}=10^{4} \mu \mathrm{m}\right)$. Desta forma, a diferença de energia, $\Delta E$, da vibração é igual à diferença $E_{2}-E_{1}$, podendo ser correlacionada diretamente com a freqüência, ou seja, quando maior a energia maior a freqüência de vibração.

\subsection{Teoria Eletromagnética Quântica}

As leis de Newton para a mecânica e gravitação vinham sendo aperfeiçoadas desde o Século XVII, e descreviam com grande precisão o comportamento dos corpos celestes e terrestres [12]. Por outro lado, as propriedades elétricas e magnéticas haviam sido unificadas em uma teoria eletromagnética por James Maxwell [8]. Esta teoria provou que a luz é uma forma de onda eletromagnética que se propaga pelo espaço.

Com as regras para o comportamento da matéria e das ondas definidas, restaria aos físicos apenas o trabalho de aplicá-las. Não haveria fenômenos que não pudessem ser explicados; haveria apenas o trabalho de desenvolver as técnicas existentes para sistemas complexos.

Lorde Kelvin, respeitado por suas importantes contribuições a Física, chegou a sugerir que a Física havia atingido seu limite. No entanto, como ele mesmo observou, havia um porém, uma vez que dois fenômenos ainda estavam sem explicação: o experimento de 
Michelson e Morley [14], que procuravam determinar a velocidade da luz que incidia na Terra vinda de diferentes direções, e o estudo da distribuição de energia da luz emitida por sistemas conhecidos como corpos negros.

O primeiro experimento indicou que a velocidade da luz que atinge a Terra é a mesma em qualquer direção. Tal fato levou Einstein a considerar que a velocidade da luz é a mesma para qualquer referencial, o que resultou na elaboração da Teoria da Relatividade Especial.

O segundo experimento, refere-se à radiação eletromagnética emitida por corpos negros que reemitem toda a radiação que incide sobre eles. Este experimento permite o estudo da forma como a radiação e o corpo interagem. O problema foi analisado pelo físico Max Planck, o qual levou a uma revolução na teoria física ao revelar que o comportamento de pequenos sistemas obedecem regras que não podem ser explicadas pelas leis das teorias clássicas [15].

Max Planck, nascido na Alemanha em 1858, foi um excelente aluno, obtendo o grau de doutor com apenas 21 anos. O estudo sobre radiação de corpos negros, que levou a origem da teoria quântica, tinha algo de absoluto, pois segundo a definição de Gustav Kirchhoff - professor de Planck - a característica de um corpo negro perfeito é sua capacidade de reemitir toda radiação que incide sobre ele; é um emissor e um absorvedor perfeito.

A radiação emitida foi estudada para diferentes temperaturas do sistema. Quando um corpo é aquecido, emite radiação cuja natureza muda com a temperatura. Um metal por exemplo, quando aquecido pode emitir radiação visível, na forma de luz vermelha, ou invisível a nosso olhos, como o infravermelho.

Planck verificou uma nova forma de encarar o modo de como as partículas da caixa na qual eram conduzidos os experimentos, geravam a radiação eletromagnética; porém, uma nova teoria seria necessária para explicar o comportamento da radiação emitida por corpos negros.

Classicamente, espera-se que as partículas da caixa utilizadas no experimento, oscilem com qualquer energia (permitida para uma dada temperatura), e assim emitam radiação a qualquer comprimento de onda ou freqüência. No entanto, para que Planck obtivesse sua fórmula, as partículas oscilando só poderiam emitir a radiação por pacotes, e a energia destes seria proporcional à freqüência na forma $E=h \nu$. A constante h ficou conhecida como constante de Planck. Assim, a energia emitida seria discretizada, ou, quantizada.

A hipótese da discretização das energias de partículas vibrando, por parte de Planck, não encontrava nenhuma situação análoga na época. Era tão radical que, mesmo reproduzindo exatamente uma observação experimental, não foi aceita até que viesse a ser adotada por Albert Einstein em 1905 [16]. 


\subsection{Teoria Clássica e Quântica da Espectroscopia Vi- bracional e Rotacional}

As interações relativas à componente do campo elétrico da radiação eletromagnética e dos movimentos de dipolos elétricos das moléculas são a base da teoria clássica das interações vibracionais. Como o espectro na região do infravermelho corresponde àquele obtido por alterações no comportamento vibracional, podemos supor, que os átomos em uma molécula são esferas rígidas unidas por pequenas molas que obedecem à lei de Hooke.

Esta lei descreve que a força de restauração, de um sistema oscilante à posição de equilíbrio, é diretamente proporcional ao deslocamento do ponto de equilíbrio,

$$
F=-f x
$$

A constante $f$ é uma medida da resistência ao movimento oscilatório; o deslocamento, $x$, das massas a partir da posição de equilíbrio, $r_{e}$, é determinado por

$$
x=r-r_{e}
$$

O momento de dipolo é definido como sendo o produto da magnitude da carga elétrica de cada molécula pela distância que separa os componentes positivo e negativo destas cargas. O momento de dipolo é representado por um vetor $\vec{p}$, conforme apresentado na figura 1.3 .

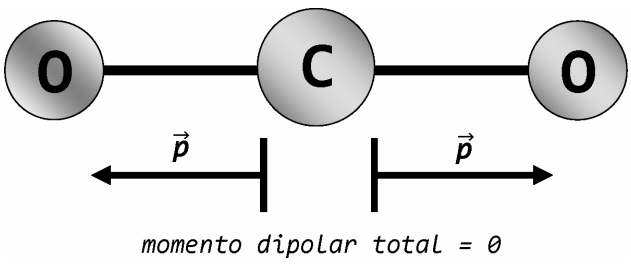

Figura 1.3: Ilustração do momento de dipolo, $\vec{p}$ de uma molécula de dióxido de carbono, onde " $O$ " representa um átomo de oxigênio e " $C$ ", um átomo de carbono.

A freqüência de vibração de uma molécula depende da forma da energia potencial da molécula, da geometria molecular, das massas dos átomos e eventualmente do acoplamento vibrônico, ou seja, o acoplamento entre o primeiro e o segundo estados eletrônicos excitados.

Se a freqüência, $\nu$, da radiação incidente é equivalente à freqüência natural de vibração da molécula, a radiação será absorvida desde que sejam atendidas determinadas condições: para que uma vibração seja detectada no espectro infravermelho, a molécula necessita sofrer uma variação no seu momento dipolar durante essa vibração. 
Em particular, na aproximação de Born-Oppenheimer [17] e em aproximações harmônicas, isto é, quando o hamiltoniano molecular corresponde ao estado padrão eletrônico, este pode ser aproximado por um oscilador harmônico quântico.

As freqüências vibracionais de ressonância são determinadas pelos modos normais correspondentes à energia potencial do estado eletrônico padrão. Não obstante, as freqüências de ressonância podem ser, em uma primeira aproximação, relacionadas ao tipo de ligação e às massas dos átomos, conforme a expressão 1.8

$$
\nu_{e}=\frac{1}{2 \pi} \sqrt{\frac{f}{\mu}},
$$

sendo que $\mu$ é a massa reduzida dos átomos que compõem a molécula; determinada através da relação,

$$
\frac{1}{\mu}=\frac{1}{m_{1}}+\frac{1}{m_{2}}
$$

A espectroscopia infravermelha está relacionada com alterações de energias vibracionais e rotacionais. Através da mecânica quântica podemos verificar que os movimentos vibracionais são quantizados; o cálculo de energia para o oscilador harmônico mostra que

$$
E_{v i b}=\left(i+\frac{1}{2}\right) h \nu
$$

onde $i$ é um número natural inteiro positivo. Observando-se ainda que as transições vibracionais permitidas para o oscilador harmônico são aquelas em que $\Delta n= \pm 1$, as bandas que obedecem a esta regra de seleção são denominadas bandas fundamentais,conforme ilustrado na figura 1.4 .

Entretanto, nenhuma molécula apresenta comportamento harmônico perfeito. Freqüentemente, nos deparamos com comportamentos que apresentam desvios em relação a este tipo de oscilador. Neste caso, dizemos que estamos na presença de um oscilador anarmônico (figura 1.4).

Para este caso, as regras de seleção permitem o aparecimento de transições onde $\Delta n= \pm 1,2,3 \ldots$. As transições com $\Delta n \geq 2$ são comumente chamadas de sobretons e apresentam freqüências que são 2,3 ou $\Delta n$ vezes maiores do que as freqüências fundamentais. 


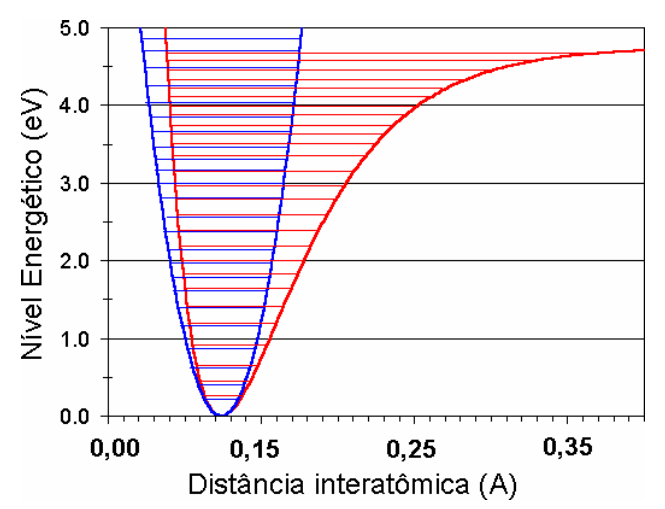

Figura 1.4: Esquema ilustrativo da energia de um oscilador harmônico (azul) e anarmônico (vermelho). As linhas horizontais representam os níveis energéticos dos estados vibracionais. Imagem: adaptada de http://www.unb.br/iq/kleber/CursosVirtuais/ QQ/aula-10

\subsection{Espectroscopia na Região do Infravermelho}

Sir Isaac Newton, demonstrou que a luz solar poderia ser decomposta em diferentes cores através de um prisma; posteriormente, William Herschel [18] idealizou um experimento utilizando um prisma, papelão e termômetros com bulbos pretos para medir as temperaturas das diferentes cores. Herschel observou um aumento da temperatura à medida que movia o termômetro do violeta para o vermelho no espectro criado pela luz do Sol atravessando o prisma. Descobriu que a maior temperatura ocorria, de fato, além da luz vermelha e que a radiação que causou esse aquecimento não era visível; denominando esta radiação invisível como "raios caloríficos", conhecidos atualmente como radiação infravermelha.

A radiação infravermelha corresponde, aproximadamente, à parte do espectro eletromagnético situada entre as regiões do visível e das microondas. Esta faixa pode ser subdividida em três regiões: a do infravermelho próximo, situada entre 12800 e $4000 \mathrm{~cm}^{-1}$; a do infravermelho médio, situada entre 4000 e $300 \mathrm{~cm}^{-1}$, e por fim, a do infravermelho distante, situada na região compreendida entre $300 \mathrm{e} 10 \mathrm{~cm}^{-1}$. A porção de maior utilidade na caracterização de compostos orgânicos está situada entre 4000 e $400 \mathrm{~cm}^{-1}$.

Embora o espectro de infravermelho seja característico da molécula como um todo, certos grupos de átomos dão origem a bandas que ocorrem próximas a uma mesma freqüência, independentemente da estrutura da molécula. É justamente a presença destas bandas características de grupos que permite a obtenção de informações estruturais úteis. As bandas de absorção que serão utilizadas neste estudo são as que ocorrem entre $4000 \mathrm{~cm}^{-1}$ e $400 \mathrm{~cm}^{-1}$. A freqüência ou o comprimento de onda de uma banda de absorção depende das massas relativas dos átomos, das constantes de força das ligações e da geometria dos átomos. 
As posições das bandas no espectro infravermelho são apresentadas em número de onda, cuja unidade é o $\mathrm{cm}^{-1}$. Conforme citado anteriormente, na seção 1.1, esta unidade é proporcional à energia de vibração das moléculas.

As intensidades das bandas podem ser expressas como transmitância $(T r)$ ou absorbância $(A b s)$. A transmitância é a razão entre energia radiante transmitida por uma amostra e a energia radiante que nela incide. A absorbância é o logaritmo decimal do inverso da transmitância, isto é,

$$
\text { Abs }=\log _{10}\left(\frac{1}{T r}\right) \text {. }
$$

As vibrações moleculares podem ser classificadas em deformações axiais e deformações angulares. Uma vibração de deformação axial é um movimento rítmico ao longo do eixo da ligação que faz com que a distância interatômica aumente e diminua alternadamente. As vibrações de deformação angular correspondem a variações ritmadas de ligações que têm um átomo em comum ou o movimento de um grupo de átomos em relação ao resto da molécula sem que as posições relativas dos átomos do grupo se alterem [19].

O número teórico de vibrações fundamentais (freqüências de absorção) raramente é observado porque as bandas correspondentes são acompanhadas por vibrações harmônicas (múltiplos de uma dada freqüência fundamental) e de combinação (a soma de duas outras vibrações). Além disso, outros fenômenos reduzem o número de bandas, como por exemplo:

- freqüências fundamentais que caem fora da região $4000-400 \mathrm{~cm}^{-1}$;

- vibrações fundamentais muito fracas para serem observadas;

- vibrações fundamentais tão próximas que se sobrepõem;

- ocorrência de bandas degeneradas provenientes de várias absorções de mesma freqüência em moléculas de alta simetria;

- a não-observação de vibrações fundamentais que não provocam alteração no momento de dipolo da molécula.

Pode-se estimar a freqüência aproximada das deformações axiais pela aplicação da lei de Hook, conforme discutido na seção 1.3. A equação a seguir, estabelece a relação entre a freqüência de oscilação, as massas atômicas e a constante de força da ligação;

$$
\bar{\nu}=\frac{1}{2 \pi c} \sqrt{\frac{f}{\left(M_{x} M_{y}\right) /\left(M_{x}+M_{y}\right)}},
$$

sendo que $\bar{\nu}$ é a freqüência vibracional, dada em $\left(\mathrm{cm}^{-1}\right), c$ é a velocidade da luz $(\mathrm{cm} / \mathrm{s})$, $f$ é a constante de força da ligação (dyn/cm) e $M_{x}$ e $M_{y}$ são as massas dos átomos x e 
y, respectivamente. O valor de $f$ é aproximadamente igual a $5 \times 10^{5} \mathrm{dyn} / \mathrm{cm}$ [19] para ligações simples e aproximadamente duas ou três vezes este valor para ligações duplas e triplas, respectivamente.

\subsection{Espectrômetro de Infravermelho com Transfor- mada de Fourier}

Durante muitos anos, obtinham-se os espectros de infravermelho com o auxílio de um feixe de luz infravermelha passado através da amostra freqüência por freqüência. A radiação transmitida era varrida por dispersão na rede de difração (grade de difração) e com isso, o espectro era obtido pela rotação da rede de difração, onde as bandas de absorção eram detectadas e lançadas em gráficos das freqüências em função das intensidades.

Atualmente, todos os instrumentos comerciais para medições na região do infravermelho médio, vendidos para aplicações analíticas, são baseados em medições interferométricas - sendo por isso classificados como instrumentos para o infravermelho com transformada de Fourier (FTIR). Atualmente, provavelmente não há mais do que 5\% de instrumentos por dispersão sendo utilizados em serviços de análises na região do infravermelho médio [20].

Nas próximas seções, será descrito o funcionamento do espectrômetro com FTIR; sendo o princípio de funcionamento do mesmo baseado no mecanismo empregado no interferômetro de Michelson.

\subsubsection{Interferômetro de Michelson}

O monocromador é o principal componente do espectrômetro por dispersão, e o mesmo se aplica no caso de instrumentos com transformada de Fourier (FT). Na figura 1.5 é apresentado um diagrama esquemático de um interferômetro de Michelson clássico.

O feixe de radiação a partir da fonte é separado por um divisor de feixes ("beamsplitter") semi transparente, em dois feixes parciais que são refletidos, um através de um espelho fixo e outro através de um espelho móvel; tais feixes retornam ao divisor de feixes onde são recombinados, causando a interferência. A fração diretamente retornada para a fonte não é utilizada, sendo portanto, perdida.

O deslocamento do espelho móvel faz com que o caminho óptico mude no interferômetro, fazendo desta forma que a diferença de fase entre os feixes parciais resultem em mudanças na amplitude da interferência. A intensidade do sinal a partir do detector, é uma função das mudanças do caminho óptico corrigida por uma componente constante, denominada interferograma. 


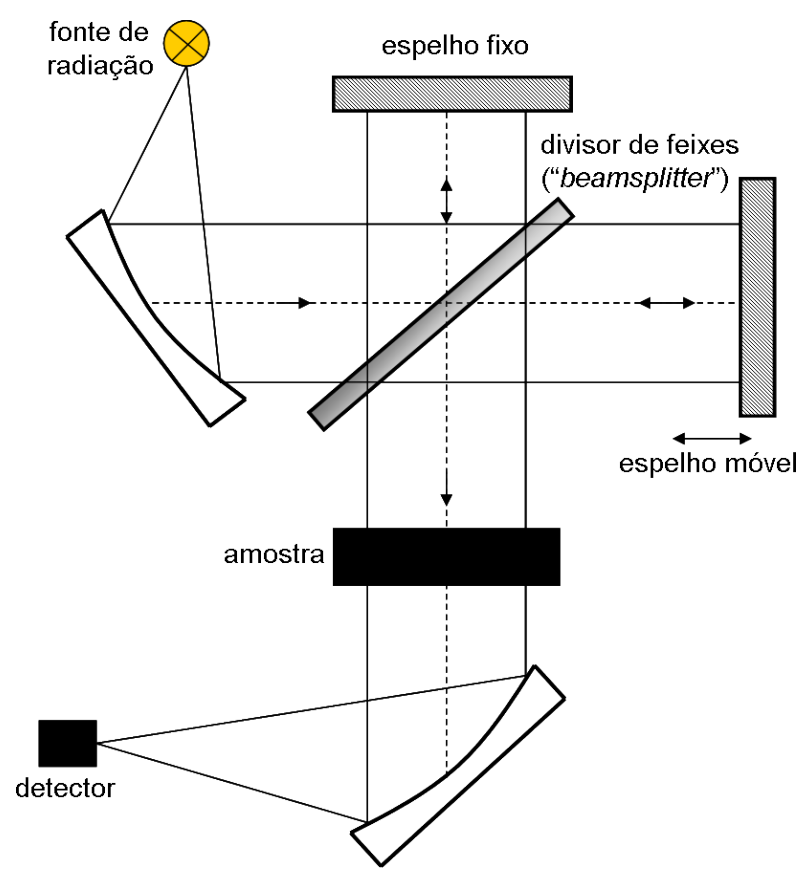

Figura 1.5: Diagrama esquemático de um espectrômetro com transformada de Fourier, com um interferômetro de Michelson clássico. Imagem: adaptada de Johnston, S., Fourier transform infrared: a constantly evolving technology, 1991.

Para uma fonte de radiação monocromática, com comprimento de onda $\lambda$ ou número de onda $\nu$, dado por um laser, o cosseno do sinal (intensidade parcial da intensidade do feixe $I_{0}$ ) é obtida no detector com sendo função da diferença de caminho $C_{o}$, a qual é denominada "retardo":

$$
I(x)=I_{0}\left[1+\cos \left(2 \pi \nu C_{o}\right)\right] .
$$

Com o mesmo caminho óptico em ambos os lados do interferômetro, não há diferença de fase entre os dois feixes parciais, os quais podem interferir construtivamente, ou seja, ambos os picos de ondas elétricas são adicionados. Se o espelho móvel se deslocar $\lambda / 4$, haverá um retardo entre os feixes parciais de exatamente $\lambda / 2$ e uma diminuição da interferência no detector.

Para fontes de radiação com vários comprimentos de onda, a interferência padrão corresponde à soma dos cossenos dos sinais de cada freqüência individual. Os interferogramas simétricos obtidos podem ser convertidos em um espectro através da transformada de Fourier,

$$
S(\nu)=\int_{-\infty}^{+\infty} I(x) \cos (2 \pi \nu x) d x
$$

O resultado é igualmente uma função simétrica para a qual os dados espectrais são duplicados, espelhados no ponto zero. A transformação reversa é possível sem que haja 
perda de informação.

Na maioria dos casos, o interferograma obtido experimentalmente é assimétrico, com relação aos vários deslocamentos de fase nos vários comprimentos de onda, resultante de efeitos ópticos e eletrônicos; devido a isso, uma transformada de Fourier mais complexa é necessária, como por exemplo a inclusão de termos relativos ao seno.

Por razões técnicas, o interferograma não é obtido continuamente e sim, ponto a ponto. Devido a este fato, o padrão de interferência de uma luz monocromática, isto é, o laser de He-Ne é simultaneamente detectado através de um diodo detector.

O cruzamento do zero, do seno do sinal do laser de referência ou valores múltiplos deste intervalo, definem os pontos de retardo e a partir destes, o interferograma é digitalizado.

A distância $\Delta x$ entre dois pontos do interferograma determina, devido a razões teóricas (princípio de "aliasing" [21]), a freqüência máxima ou comprimento de onda que pode ser claramente detectado. Por outro lado, nenhum sinal randômico pode ser digitalizado sem acarretar em perda de informação quando a freqüência de amostragem utilizada é menor ou no mínimo equivalente a duas vezes a largura da banda do sinal medido. Isto é denominado critério de amostragem de Nyquist [20],

$$
\nu_{\operatorname{máx}}-\nu_{\operatorname{mín}}=\frac{1}{(2 \Delta x)} .
$$

Conforme mencionado anteriormente, a transformada de Fourier de um interferograma fornece o espectro, sendo esta uma imagem espelhada. A transformada de Fourier discreta da função digitalizada agora nos conduz para a situação à qual a réplica infinita desta é produzida ao longo do eixo do comprimento de onda. Com isto, outras regiões espectrais são calculadas, as quais respectivamente estão entre os limites máximos e mínimos da convolução.

Para satisfazer o critério de Nyquist, o computador deve ir realizando correções espectrais nos intervalos limites, enquanto a potência espectral da radiação medida não for nula $[22]$.

Para instrumentos com varredura lenta, o espelho se move com velocidade constante ou com passos discretos (passo-varredura). O feixe é modulado com um motor de passo mecânico e detectado com sensibilidade de fase.

O interferograma mais eficiente para a região do infravermelho próximo e médio porém, pode ser obtido com interferômetros de varredura rápida, sem a utilização de um motor de passo. Neste caso, a radiação é utilizada de maneira mais apropriada, pois o detector não é exposto a nenhuma fase de "escuridão". O requisito, porém, é a disponibilidade destes detectores rápidos; dependendo do detector utilizado, a velocidade dos espelhos pode acarretar em erros da ordem de $0,05 \mathrm{~cm}^{-1}$ até $5,0 \mathrm{~cm}^{-1}$.

Para interferômetros de Michelson típicos, as freqüências ópticas ou comprimentos 
de onda podem ser transformados em intervalos de freqüências acústicas, utilizando a seguinte técnica [20, 11]: com a velocidade do espelho dada por $c_{s}$, temos uma equação que a relaciona com a freqüência da seguinte maneira,

$$
\nu_{s}=2 c_{s} \nu
$$

As freqüências máximas são geralmente menores que $100 k H z$. Conseqüentemente, a necessidade de uma amplificação da largura de bandas do sinal do detector é linear para todas as freqüências.

Tipicamente, muitos interferogramas possuem mecanismos para melhora da razão sinal-ruído. Para isto, um ponto de referência é definido para os sinais, de forma que seja obtido um valor médio e o mesmo seja digitalizado.

Devido a estas limitações experimentais, cada interferograma pode ser somente ajustado a um limite máximo de retardo. O menor $\Delta \nu$ é obtido com o maior retardo possível, $x_{\max }$ Em geral, para obtermos a resolução espacial, podemos aplicar a equação

$$
\Delta \nu=\frac{1}{2 x_{\operatorname{máx}}} .
$$

Com algumas exceções, os espectrômetros com FT são concebidos como instrumentos de feixe simples. A figura 1.6 ilustra um instrumento comercial.

A maioria dos espectrômetros possuem um interferômetro incorporado, além de que a posição dos espelhos do interferômetro deriva $90 \%$ do arranjo do interferômetro de Michelson clássico.

Esta conformação é adotada devido à diversos fatores; dentre eles, podemos citar: o aumento da eficiência do divisor de feixes, redução dos efeitos de polarização, assim como aumento na energia de saída, a qual está relacionada ao tamanho do divisor de feixes.

Neste caso, o interferograma não é produzido como nos demais casos, através do deslocamento linear do espelho móvel e sim através do movimento extremamente preciso de um fluxo de ar, que faz com que um par de espelhos se rotacionem, conforme mostrado na figura 1.7. A vantagem principal deste sistema de rotação é o fato que o ajuste no caso da existência de feixes remanescentes é feito de maneira constante durante a rotação [23]. 


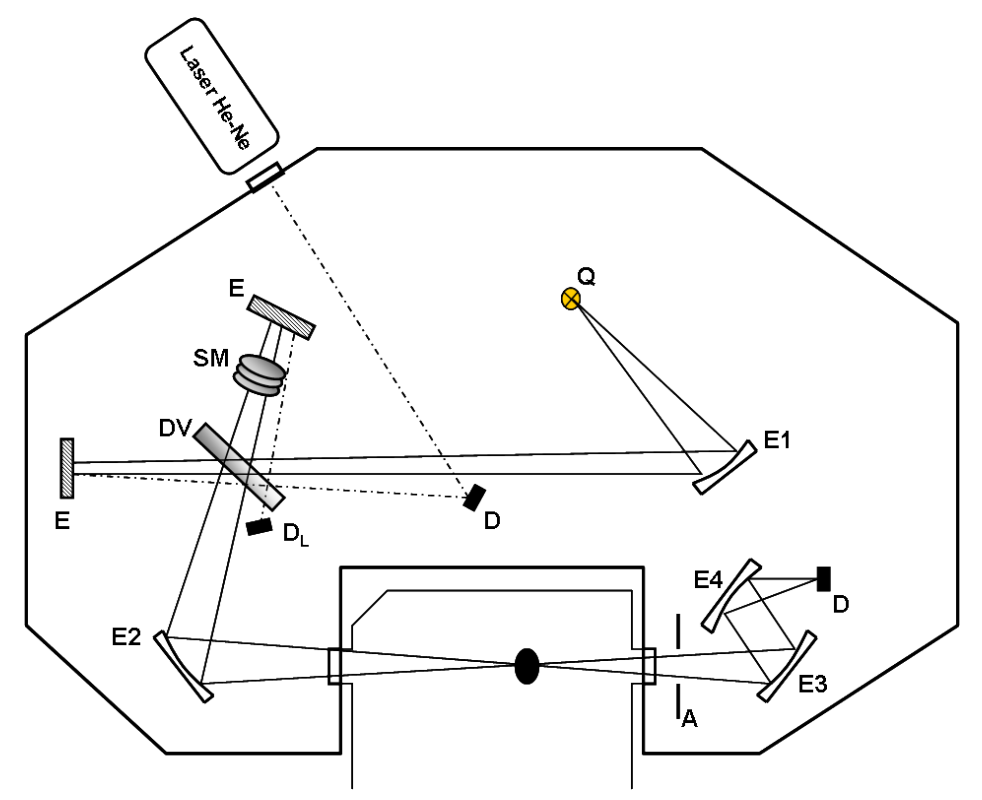

Figura 1.6: Diagrama óptico de um espectrômetro comercial, sendo o arranjo do interferômetro de Michelson clássico a base deste modelo. Q, representa a fonte de radiação; DV, é o divisor de feixes; SM, é o scanner mecânico; A, é a abertura; D, é o detector e $D_{L}$, o detector do laser; E1-E4 são espelhos de foco e E, espelhos planos. Imagem: adaptada de Johnston, S., Fourier transform infrared: a constantly evolving technology, 1991.

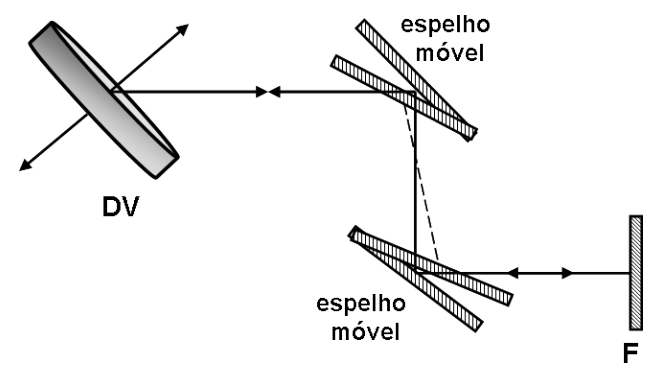

Figura 1.7: Mudança do caminho óptico através da rotação de um par de espelhos, onde DF é o divisor de feixes e F, o espelho fixo. Imagem: adaptada de Johnston, S., Fourier transform infrared: a constantly evolving technology, 1991.

\subsubsection{Vantagens dos Espectrômetros com Transformada de Fourier}

Há muitas publicações as quais evidenciam comparações entre os vários tipos de instrumentos existentes $[24,25,26,27]$. De acordo com várias dessas comparações, podemos notar que há muito tempo as vantagens do espectrômetro com FT vem sendo enfatizadas, principalmente quando o mesmo é comparado com instrumentos de dispersão.

A primeira delas é conhecida como "vantagem múltipla", denominada assim pelo espectroscopista Fellgett [28]. Todos os comprimentos de onda são medidos simultane- 
amente no interferômetro, enquanto estes são medidos no monocromador sucessivamente. Considerando os ruídos tipicamente observados na região do infravermelho médio e distante, os espectrômetros com FT são superiores por duas razões: a cada mudança no espelho móvel é realizada uma varredura completa de todo o espectro e com isso, varreduras individuais são combinadas resultando numa melhor representação da absorbância da amostra, acarretando a diminuição do ruído e permitindo a coleta de vários espectros num tempo inferior à varredura realizada pelo instrumento dispersivo, o qual varre cada comprimento de onda uma única vez [24].

A segunda vantagem é conhecida como a "vantagem de Jacquinot" [29]; considerandose a mesma resolução espectral, a luz conduzida ao espectrômetro com FT, pode ser maior que aquela conduzida num instrumento dispersivo, o qual é equipado com um monocromador com duas fendas. Considerando-se a mesma capacidade de resolução, os interferômetros apresentam uma condutibilidade óptica, com mais de duas ordens de grandeza maior que os espectrômetros com grades [26]. Esta vantagem não é constante com relação a variação da dispersão, dependente do ângulo da grade de difração, mas diminui com um fator $\nu^{2}$. A razão sinal-ruído para espectrômetros com FT, foi estimada por Mattson [27] num estudo onde a variação de diversos parâmetros foi discutida em detalhes.

A terceira vantagem está relacionada com a estabilidade espectral obtida a partir de um interferômetro; esta vantagem leva o nome de "vantagem de Connes" [30]. Esta estabilidade está relacionada ao fato de que a escala de freqüência do instrumento com FT está relacionada ao laser de He-Ne, o qual fornece uma referência interna para cada interferograma. Outro aspecto a ser considerado é o fato de que o espalhamento é negligenciado, uma vez que a posição da amostra é tipicamente alterada com relação a modulação do interferômetro.

\subsection{A célula e suas Macromoléculas}

Num primeiro momento é difícil aceitar a idéia de que cada um dos organismos vivos seja meramente um sistema químico. Até o século XIX foi amplamente aceito que o animais tinham uma força - um "animus" - que era responsável pelas suas características. [31]

Sabe-se atualmente, que não há nada nos organismos vivos que não obedeça as leis da química e da física. Os organismos vivos são fundamentalmente baseados em compostos de carbono; em segundo lugar, as células são formadas em $70 \%$ por água e a vida depende quase que exclusivamente de reações que ocorrem em soluções aquosas.

Em terceiro lugar, e mais importante, a química das células é extremamente complexa - mesmo a mais simples das células possui uma química muitíssimo mais complexa do que qualquer outro sistema químico conhecido. Todas as características de uma célula dependem das moléculas que a mesma possui. 
Uma molécula é definida como um agrupado de átomos que são mantidos unidos por meio de ligações covalentes, isto é, os átomos completam suas camadas externas através do compartilhamento de elétrons e não pela troca dos mesmos.

Desconsiderando a água, praticamente todas as moléculas de uma célula possuem o carbono como base. Em comparação com todos os demais elementos, o carbono possui uma grande capacidade de formar moléculas grandes, compostas por mais de 50 átomos de carbono. Devido ao fato de possuir quatro elétrons na última camada, o átomo de carbono pode formar quatro ligações covalentes com outros átomos; o mais importante é o fato de que um átomo de carbono pode ligar-se com outros átomos de carbono por meio da ligação covalente $\mathrm{C}-\mathrm{C}$, que é altamente estável, de modo a formar cadeias e anéis e, conseqüentemente, formar moléculas grandes e complexas.

As moléculas orgânicas pequenas das células, são compostos baseados no carbono e com peso molecular na faixa de 100 a 1000 u.a., contendo cerca de trinta átomos de carbono [32]; geralmente, tais moléculas são encontradas livres em solução; algumas são sub unidades - monômeros - utilizadas na construção de grandes macromoléculas poliméricas das células, tais como: as proteínas, os ácidos nucléicos e os grandes polissacarídeos. Outras agem como fonte de energia e são degradadas e transformadas em outras moléculas pequenas no emaranhado de vias metabólicas intracelulares.

Desta forma, podemos classificar de maneira grosseira, que as células contém quatro famílias principais de moléculas orgânicas pequenas: os açúcares, os ácidos graxos, os aminoácidos e os nucleotídeos, conforme esquematizado na figura 1.8 .

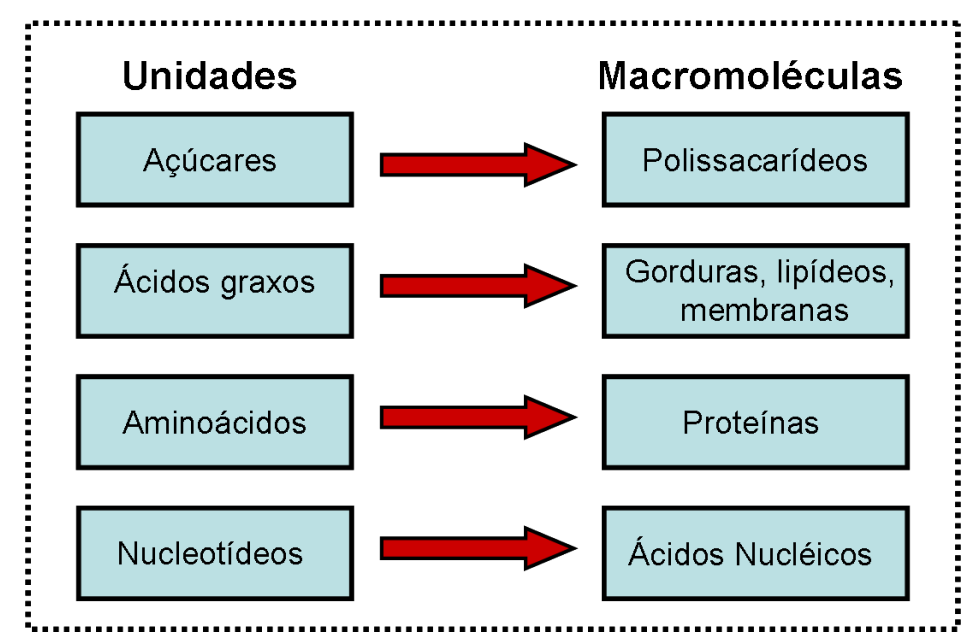

Figura 1.8: Esquema ilustrando as quatro famílias principais de moléculas orgânicas presentes nas células. No quadro são apresentadas as unidades básicas e as respectivas macromoléculas, as quais são compostas por tais unidades. Imagem: adaptada de Alberts, B., Molecular biology of the cell, 2002.

Embora muitos dos compostos presentes nas células não se enquadrem nestas categorias, as quatro famílias de moléculas pequenas juntamente com as macromoléculas 
formadas por suas ligações e longas cadeias, correspondem a uma grande proporção da massa celular [33].

\subsubsection{Açúcares e Polissacarídeos}

Os açúcares mais simples - os monossacarídeos - são compostos com fórmula geral $\left(\mathrm{CH}_{2} \mathrm{O}\right)_{n}$, onde $n$ é um inteiro que varia de 3 a 8 . Os açúcares podem existir na forma de anel ou formar uma cadeia aberta; quando estes estão agrupados sob a forma de cadeia aberta, os açúcares contém um certo número de grupos hidroxila e um grupo aldeído $(\mathrm{HC}=\mathrm{O})$ ou cetona $(\mathrm{C}=\mathrm{O})[34,33]$.

Os grupos aldeído ou cetona desempenham um papel importante: primeiramente, este pode reagir com um grupo hidroxila da mesma molécula, convertendo-a num anel. Este grupo pode ser identificado facilmente, uma vez que, na forma de anel, o carbono do aldeído ou da cetona original é o único que se liga a dois oxigênios. Segundo, uma vez que o anel esteja formado, esse mesmo carbono pode ligar-se ainda a um dos carbonos que estão ligados a grupos hidroxila de uma outra molécula de açúcar, criando um dissacarídeo, como a sacarose (que é composta de uma unidade de glicose e uma de frutose).

O monossacarídeo glicose tem um papel central como fonte de energia para as células. Em uma série de reações, a glicose é degradada em moléculas menores, liberando energia $[32]$.

Os açúcares não são responsáveis somente pela produção e armazenamento de energia; eles também podem ser utilizados, por exemplo, para dar sustentação mecânica, tais como a celulose (componente das paredes vegetais) e a quitina (componente do exoesqueleto de insetos e parede celular de fungos) [32]. Os polissacarídeos de vários outros tipos são os componentes principais do muco e da cartilagem dos animais.

As células utilizam polissacarídeos simples, compostos unicamente de unidades de glicose - principalmente glicogênio nos animais (figura 1.9) e amido nas plantas - como reservas de energia de longo prazo.

O glicogênio é um polissacarídeo composto por glicose (Glc), que funciona a curto prazo como fonte de armazenamento secundária de energia em células animais. A síntese dos mesmos é realizada principalmente pelo fígado e músculos, mas também pode ser realizada pelo cérebro e estômago [33]. 


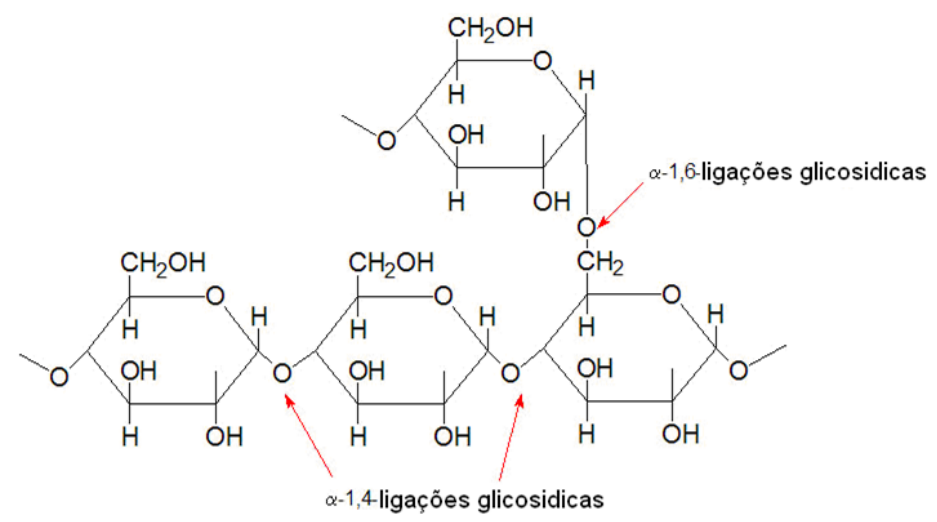

Figura 1.9: Estrutura química da molécula de glicogênio, polissacarídeo composto por unidades de glicose, as quais atuam como reservas de energia de longo prazo. Imagem: adaptada de Alberts, B., Molecular biology of the cell, 2002.

O glicogênio é um análogo do amido, um polímero de glicose menos ramificado, proveniente de plantas; este é encontrado na forma de grânulos no citosol (líquido que preenche o citoplasma celular) em muitos tipos de células, e desempenha um papel importante no ciclo da glicose. O glicogênio constitui uma reserva de energia que pode ser rapidamente mobilizada para atender a uma súbita necessidade de glicose, porém é menos compacta do que as reservas energéticas de triglicérides (gordura) [34, 32].

Os oligossacarídeos pequenos podem ser ligados a proteínas, formando glicoproteínas, e a lipídeos, formando glicolipídeos, que são encontrados nas membranas celulares. Os monossacarídeos encontrados comumente em humanos são classificados de acordo com o número de carbonos que estes contêm em seus esqueletos estruturais. Os maiores monossacarídeos possuem de quatro a seis átomos de carbono.

A maior parte dos carboidratos encontrados na natureza ocorrem sob a forma de polímeros com alta massa molecular, denominados polissacarídeos [32, 33]. As unidades as quais compõem os polissacarídeos podem ser variadas; porém em todos os casos, o monossacarídeo predominante é a glicose-D.

\subsection{2 Ácidos Graxos, Gorduras, Lipídeos e Membranas}

Uma molécula de ácido graxo possui duas regiões quimicamente distintas: uma é composta por uma longa cadeia hidrocarbonada, a qual é hidrofóbica e não possui muita reatividade química. A outra, é composta por um grupo carboxila $(-C O O H)$, que se comporta como um ácido; este é ionizado em solução (-COO_), é extremamente hidrofílico e reativo quimicamente $[34,33]$. A quase totalidade das moléculas de ácidos graxos de uma célula está ligada covalentemente a outras moléculas por meio dos seus grupos ácido-carboxílicos.

Nas células, os ácidos graxos funcionam como uma reserva concentrada de alimento, 
uma vez que a sua degradação produz cerca de seis vezes mais energia utilizável do que a degradação da glicose [31]. Estes são armazenados no citoplasma de muitas células na forma de gotículas de moléculas de triacilgliceróis que, por sua vez, consistem em três ácidos graxos ligados a uma molécula de glicerol.

Os ácidos graxos e seus derivados são exemplos de lipídeos [34, 31]. Os lipídeos englobam, em uma definição um tanto vaga, um conjunto de moléculas biológicas que têm a característica comum de serem insolúveis em água e solúveis em solventes de gorduras e em solventes orgânicos, tais como o benzeno. Caracteristicamente, estes contêm ou uma longa cadeia hidrocarbonatada (como nos ácidos graxos e nos isoprenos), ou são compostos por múltiplos anéis aromáticos (como nos esteróis).

A função mais importante dos ácidos graxos em uma célula é participar na construção das membranas celulares (figura 1.10); estas são compostas principalmente por fosfolipídeos que, à semelhança dos triacilgliceróis, são constituídos principalmente de ácidos graxos e de glicerol.

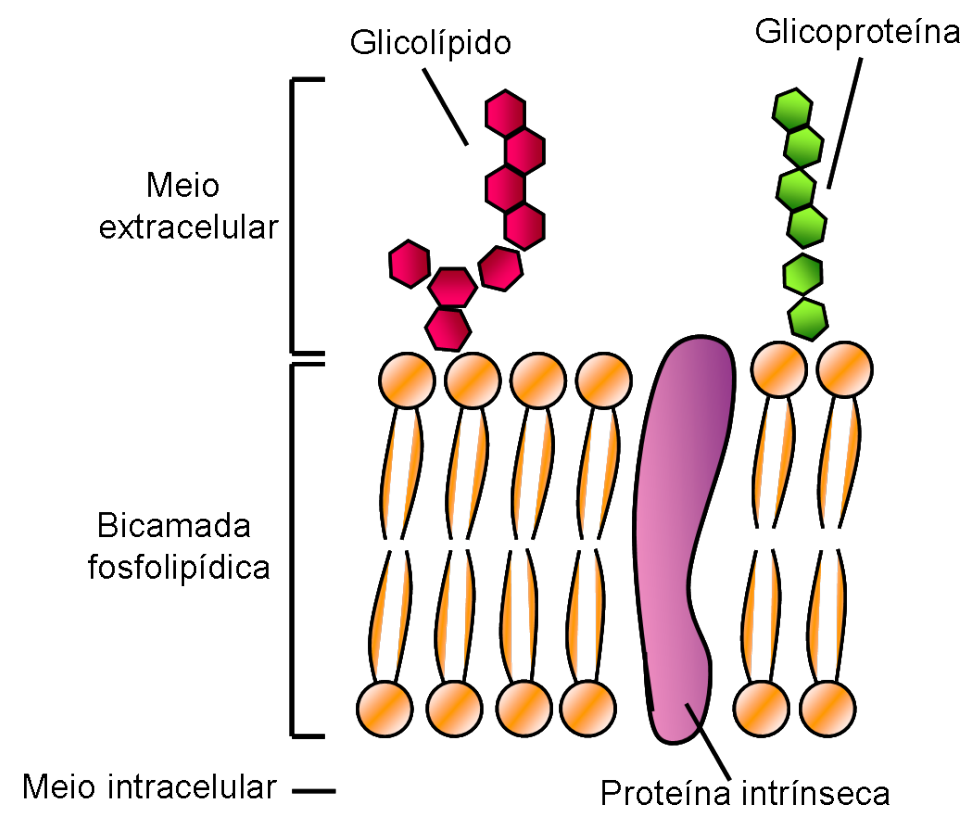

Figura 1.10: Esquema simplificado representativo da membrana celular, através do qual é possível notar a camada bilipídica, tendo os ácidos graxos como unidades que compõem a maior parte da mesma.

Nos fosfolipídeos, dois sítios do glicerol estão ligados a duas cadeias de ácidos graxos ao invés de três (como nos triacilgliceróis); o terceiro sítio do glicerol liga-se a um grupo fosfato que é hidrofílico, o qual, por sua vez, está ligado a um composto hidrofílico pequeno, como a colina. Cada molécula de fosfolipídeo, então, possui uma cauda hidrofóbica composta de duas cadeias de ácidos graxos e de uma cabeça hidrofílica, onde se localiza o fosfato [32].

A propriedade dos fosfolipídeos para formar membranas deriva desta natureza an- 
fipática. Os fosfolipídeos distribuem-se sobre a superfície da água, formando uma monocamada de moléculas com suas caudas hidrofóbicas expostas ao ar; duas camadas, quando em água, podem facilmente combinar-se cauda com cauda, formando uma bicamada lipídica, a qual constitui a base estrutural das membranas celulares.

\subsubsection{Aminoácidos e Proteínas}

Todos os peptídeos e polipéptidos são polímeros compostos por $\alpha$-aminoácidos. Há $20 \alpha$-aminoácidos que são relevantes para a composição das proteínas dos mamíferos. Porém, há diversos aminoácidos que são encontrados no organismo, no estado livre ou combinados - isto é, associados ou não com peptídeos ou proteínas [33].

Diversos aminoácidos encontrados nas proteínas realizam funções distintas, como é o caso da tirosina, na formação de hormônios tireoidianos ou agindo como um neurotransmissor, como é o caso do glutamato.

Os $\alpha$-aminoácidos em peptídeos e proteínas (excluindo-se a prolina) são constituídos por um ácido carboxílico $(-\mathrm{COOH})$ e um grupo funcional amina $\left(\mathrm{NH}_{2}\right)$ anexados ao mesmo átomo de carbono, sendo este denominado carbono- $\alpha$ [33, 31]. Através dos grupos-R, é possível distinguir um aminoácido de outro, existindo assim duas grandes classes de aminoácidos: hidrofílicos ou hidrofóbicos.

Os aminoácidos hidrofóbicos tendem a repelir o meio aquoso e, portanto, residem principalmente no interior das proteínas. Esta classe de aminoácidos não ionizam nem participam da formação de pontes de hidrogênio. Os aminoácidos hidrofílicos tendem a interagir com o meio aquoso, são freqüentemente envolvidos na formação de pontes de hidrogênio, situados predominantemente nas superfícies exteriores das proteínas ou em centros reativos das enzimas.

As proteínas são compostos orgânicos formados por aminoácidos dispostos numa cadeia linear e unidas por ligações peptídicas entre os grupos carboxila e amino dos aminoácidos. A seqüência de aminoácidos de uma proteína é definida pela seqüência de um gene, que está codificada no código genético [32].

À semelhança de outras macromoléculas biológicas, tais como polissacarídeos e ácidos nucléicos, as proteínas são partes essenciais dos organismos e participam de todos os processos dentro das células. Muitas proteínas são enzimas que catalisam reações bioquímicas e são vitais para o metabolismo. Elas também possuem funções mecânicas ou estruturais, tais como a actina e miosina nos músculos e as proteínas do citoesqueleto, que formam estruturas capazes de manter o formato celular. Outras proteínas são importantes na sinalização celular, resposta imune, adesão, bem como no ciclo celular [33, 31, 34].

Uma vez que os animais não podem sintetizar todos os aminoácidos necessários, estes precisam e devem obter aminoácidos essenciais a partir de alimentos. Através do processo de digestão, os animais quebram a proteína ingerida em aminoácidos livres que são então 
utilizados no metabolismo.

A maioria das proteínas encontram-se em estruturas únicas tridimensionais. A forma a qual uma proteína naturalmente se encontra é conhecido como o seu estado nativo. Bioquímicos frequentemente referem-se a quatro tipos distintos de estrutura de proteínas, conforme apresentado na figura 1.11. A chamada estrutura primária consiste na seqüência de aminoácidos; a estrutura secundária consiste na repetição regular das estruturas locais, estabilizadas por pontes de hidrogênio. Os exemplos mais comuns são a alfa hélice e a conformação beta. Como as estruturas secundárias são locais, diferentes estruturas secundárias podem estar presentes na mesma molécula de proteína [34, 33].

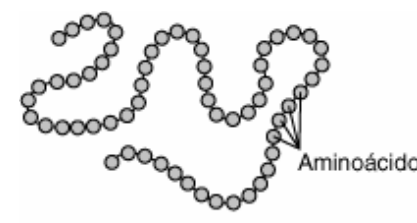

(a)

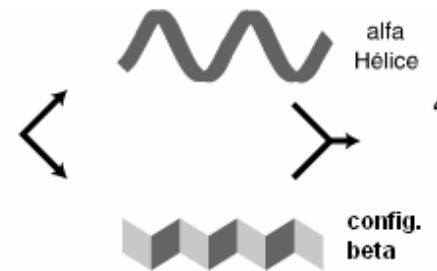

(b)

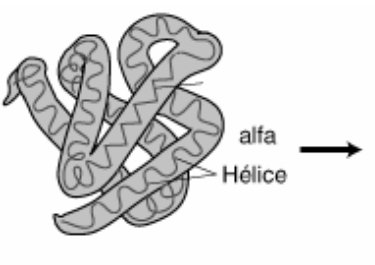

(c)

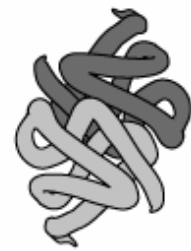

(d)

Figura 1.11: Esquema das estruturas das proteínas. Em (a) é apresentada a estrutura primária (formada por uma seqüência de aminoácido); (b) estrutura secundária, classificada em configuração beta ou alfa hélice; (c) estrutura terciária, a qual é responsável pelo controle da função básica da proteína; (d) estrutura quaternária, resultante da interação de mais de uma molécula de proteína. Imagem: adaptada de www.biomol.org

A estrutura terciária é o que controla a função básica da proteína. Esta estrutura geralmente apresenta a formação de um núcleo hidrofóbico, através de ligações com o hidrogênio e dissulfeto, assim como modificações pós-translacionais. Por fim, a estrutura quaternária resulta da interação de mais de uma molécula de proteína [34, 33].

Proteínas não são moléculas totalmente rígidas; há diversos rearranjos funcionais sendo que as estruturas terciárias ou quaternárias são geralmente referidas como "conformações", e as transições entre elas são denominadas mudanças conformacionais [34, 33]. Essas mudanças são muitas vezes induzidas pela ligação de um substrato, uma enzima no sítio ativo da molécula, ou simplesmente estão relacionadas às características físicas do ambiente no qual a proteína se encontra, como por exemplo, no meio intracelular.

\subsubsection{Nucleotídeos e Ácidos Nucléicos}

Um nucleotídeo é uma molécula formada por um anel que contém um nitrogênio ligado a um açúcar de cinco carbonos. Esse açúcar pode ser tanto a ribose quanto a desoxirribose e carrega um ou mais grupos fosfato. Os nucleotídeos que possuem ribose são conhecidos como ribonucleotídeos, e os que possuem a desoxirribose são os desoxinucleotídeos [32, 
$35]$.

Os anéis contendo um átomo de nitrogênio são ditos bases, devido à razões históricas: em condições ácidas cada um deles pode ligar um próton e, assim, aumentar a concentração de íons $\mathrm{OH}-$, quando em solução aquosa.

As diferentes bases guardam uma grande semelhança entre si. A citosina (C), a timina ( $\mathrm{T}$ ) e a uracila (U) são denominadas pirimidinas porque são derivadas do anel das pirimidinas, que têm seis átomos [35]. A guanina $(G)$ e a adenina (A) são compostos das purinas e possuem um segundo anel, de cinco membros, ligado ao anel de seis átomos, conforme apresentadas na figura 1.12. A denominação de cada um dos nucleotídeos está de acordo com a base que eles contêm.<smiles>[X]n1ccc(N)nc1=O</smiles>

Citosina<smiles>[X]n1ccc(=O)[nH]c1=O</smiles>

Uracila<smiles>[X]n1cc(C)c(=O)[nH]c1=O</smiles>

Timina

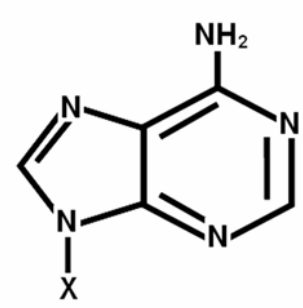

Adenina<smiles>[X]n1cnc2c(=O)[nH]c(N)nc21</smiles>

Guanina

Figura 1.12: Estrutura química dos nucleotídeos: a citosina, uracila e timina são denominadas pirimidinas; a guanina e a adenina são denominadas purinas. Imagem: adaptada de Alberts, B., Molecular biology of the cell, 2002.

O mais básico dos papéis dos nucleotídeos nas células é o armazenamento e a disponibilização de informação biológica. Os nucleotídeos servem como blocos ou módulos para a construção dos ácidos nucléicos; estes são polímeros longos nos quais as subunidades nucleotídicas ficam ligadas covalentemente, por meio da formação de ligações fosfodiéster entre o grupo fosfato ligado ao açúcar de um nucleotídeo e o grupo hidroxila do açúcar do nucleotídeo seguinte [33, 35].

Existem dois tipos principais de ácidos nucléicos e eles diferem quanto ao tipo de açúcar fosfato nas suas respectivas estruturas. Os nucleotídeos baseados no açúcar ribose são conhecidos como ácidos ribonucléicos, ou RNA ("ribonucleic acid"), e contêm as bases A, G, C e U.

Aqueles que possuem como base a desoxirribose são conhecidos como ácidos desoxirribonucléicos, ou DNA ("deoxyribonucleic acid"), e contêm as bases A, G, C e T (T é 
quimicamente semelhante à $U$ do RNA, diferindo apenas pela adição de um grupo metila ao anel pirimidínico).

A seqüência linear dos nucleotídeos no DNA e no RNA codificam a informação genética das células; a capacidade que as bases das moléculas dos diferentes ácidos nucléicos possuem de reconhecerem-se e parearem-se umas com as outras, conforme a figura 1.13, por meio de ligações do tipo pontes de hidrogênio, $G$ com $C$ e $A$ tanto com $T$ quanto $U$, fundamenta toda a evolução.

Utilizando os dados de difração de raios X, obtidos a partir de cristais de DNA, James Watson e Francis Crick propuseram um modelo para a estrutura do DNA. Este modelo (posteriormente confirmado por outros dados) previram que o DNA seria como uma helicóide de duas vertentes complementares antiparalelas, enroladas em torno de si em uma direção direita e estabilizada por pontes de hidrogênio [35].

A

$\mathbf{T}$

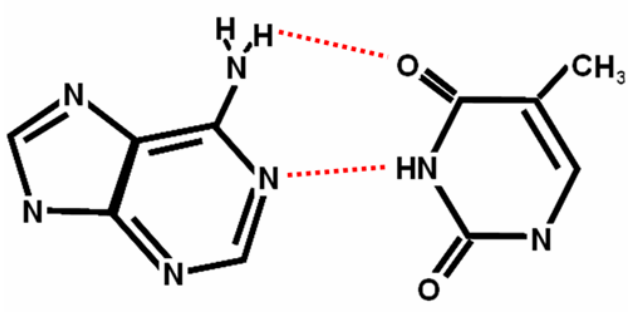

G

C

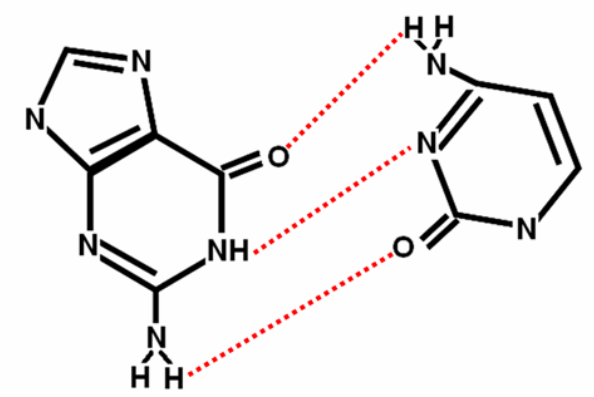

Figura 1.13: Os filamentos do DNA e do RNA são compostos por açúcares e pelas porções de fosfato dos nucleotídeos; ligadas por pontes de hidrogênio. O par composto pela adenina $(A)$ e timina $(T)$ - ou uracila $(U)$, no caso do RNA - é formado através de duas pontes de hidrogênio; os pares compostos pela guanina $(G)$ e citosina $(C)$ são ligados através de três pontes de hidrogênio. Imagem: adaptada de Alberts, B., Molecular biology of the cell, 2002.

No modelo de Watson-Crick [31], as bases estão no interior da hélice alinhadas num ângulo de quase 90 graus com relação ao eixo da hélice. Purinas e pirimidinas formam ligações do tipo ponte de hidrogênio, formando pares onde $T$ se liga com $A$ e $C$ com $G$ [35]. De acordo com este modelo, os pares de base compostos por G e C contêm três pontes de hidrogênio, enquanto que os pares de T-A contêm duas ligações. Isto torna os 
pares de base G-C mais estável do que o par T-A.

\subsection{A Bioquímica da Célula Neoplásica}

As células neoplásicas violam as regras mais básicas de comportamento pelo qual os organismos multicelulares são construídos e mantidos; estas possuem basicamente duas propriedades: ela e suas descendentes reproduzem-se desobedecendo os limites normais da divisão celular e, invadem e populam regiões normalmente destinadas à outras células. A combinação destas atividades faz com que o câncer seja uma doença particularmente perigosa. Uma célula anormal isolada que não se prolifere além da sua vizinhança normal, não causa dano significativo [36]. Se, entretanto, sua proliferação estiver fora de controle, esta dará início a um tumor, ou "neoplasia", uma massa compacta de células anormais continuamente em crescimento, conforme apresentado no esquema da figura 1.14.

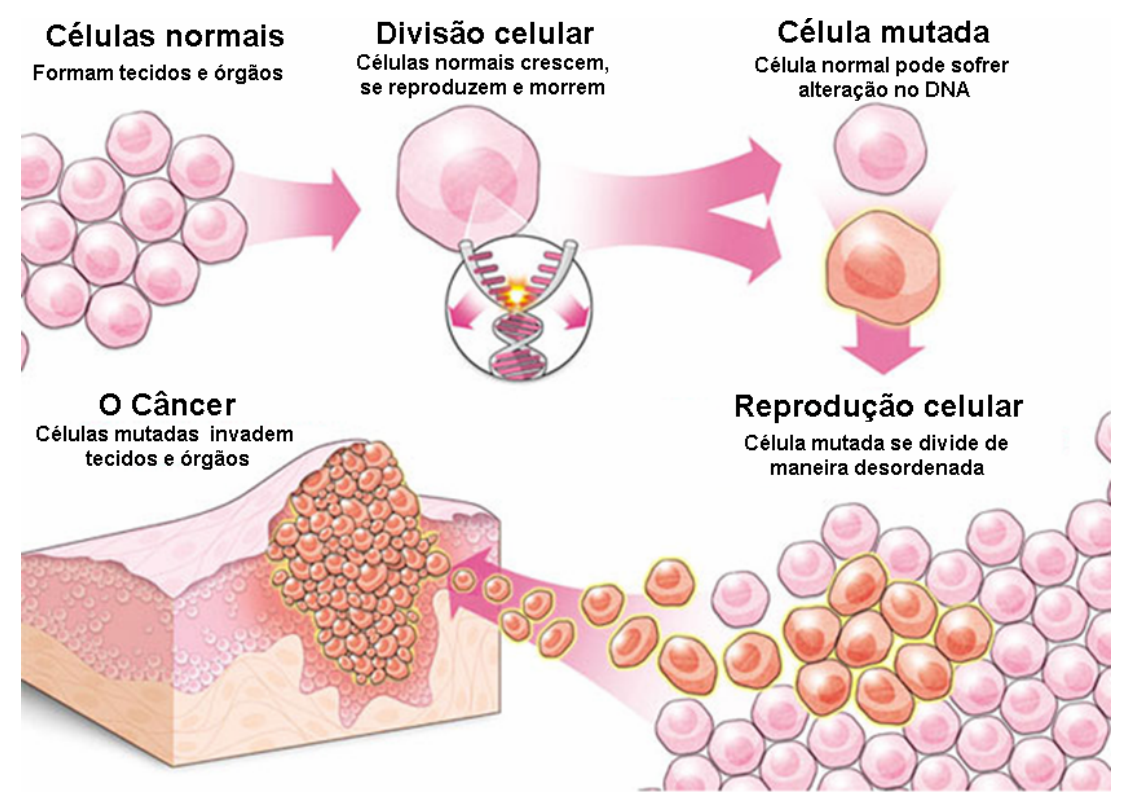

Figura 1.14: Um conjunto de células compõe tecidos e órgãos; células normais possuem seu ciclo celular bem definido, porém caso as células possuam alguma mutação que altere seu ciclo, esta faz com que as mesmas se reproduzam de maneira errônea e desordenada, dando origem a um câncer, ou seja, à multiplicação desordenada de células que invadem tecidos e órgãos adjacentes. Imagem: adaptada de www.ache.com.br/_img/ infografico.jpg

Os cânceres são classificados de acordo com os tecidos e os tipos celulares dos quais os mesmos derivam. Os cânceres derivados de células epiteliais são denominados carcinomas, e aqueles derivados do tecido conjuntivo ou de células musculares são denominados sarcomas. Os cânceres que não se enquadram em nenhuma destas duas grandes categorias, são classificados como leucemias, derivadas de células hematopoiéticas e os cânceres derivados de células do sistema nervoso [36]. 
Estima-se que durante toda a vida ocorram cerca de $10^{16}$ divisões celulares em um organismo humano normal. Mesmo num ambiente isento de agentes mutagênicos, ocorrem mutações espontâneas a uma taxa que é estimada em cerca de $10^{-6}$ mutações por gene por cada divisão celular [37]. Tais mutações ocorrem devido a limitações intrínsecas da acuidade da replicação e do reparo do DNA; desta forma, durante o tempo de vida de cada ser humano, cada um de seus genes devem sofrer mutações em cerca de $10^{10}$ ocasiões independentes.

Os genes críticos relacionados ao câncer são agrupados em duas classes, segundo o risco de o câncer decorrer de uma atividade muito aumentada ou diminuída do produto do gene $[37,36]$.

Os genes da primeira classe, nos quais uma mutação acarreta em um aumento de uma determinada função, são denominados proto-oncogenes, ao passo que seus mutantes (ou formas hiperativas) são denominados oncogenes. Os genes da segunda categoria, nos quais o câncer é ocasionado devido à perda de uma função específica, são denominados genes supressores de tumores.

De acordo com diversos trabalhos [37, 36, 32, 38], ao menos cem genes críticos relacionados ao câncer podem ser convertidos em oncogenes através de uma mutação ativadora. A lista de genes cuja ausência ou inativação leva ao câncer (genes supressores de tumores) é menor, porém devido à diversas pesquisas, a mesma está crescendo. As vias, através das quais os genes de quaisquer uma das duas classes podem ser mutados para torná-los ativos ou não, é muito variável.

O gene pode ser alterado por uma pequena modificação em sua seqüência de nucleotídeos, como uma mutação pontual; ele também pode ser modificado por uma alteração em grande escala, como uma deleção parcial. O gene, pode ainda, ser modificado por uma translocação cromossômica que envolva o rompimento e a religação da hélice do DNA [38].

Estas alterações podem ocorrer em uma região que codifique uma proteína de maneira a produzir uma proteína hiperativa ou, então, podem ocorrer em regiões reguladoras adjacentes, de forma que o gene é apenas expresso em concentrações muito maiores que as normais [38, 37].

De uma maneira geral, as etapas do avanço de um tumor podem ser correlacionadas com as mutações que ativam oncogenes específicos e inativam determinados genes supressores de tumor. Entretanto, diferentes combinações de mutações são encontradas em diferentes formas de câncer mesmo em pacientes que nominalmente possuam a mesma forma da doença. Isso reflete a maneira aleatória com que as mutações ocorrem.

À medida que o conhecimento da biologia molecular do câncer cresce, aumentando-se a capacidade de identificar diversos bio marcadores relacionados às diversas neoplasias, será possível encontrar melhores maneiras de diagnosticar e tratar esta doença, propondo tratamentos específicos para cada paciente. 


\section{Capítulo 2}

\section{Motivação e Objetivos}

A espectroscopia vibracional tem se desenvolvido ao longo dos últimos anos e atraído a atenção na Medicina, uma vez que a mesma pode ser empregada como um método auxiliar não invasivo no diagnóstico de certas doenças $[5,39,6,40,4,3]$.

Várias técnicas ópticas podem ser empregadas para diagnosticar alterações em células e tecidos biológicos; alguns exemplos são: espectroscopia de fluorescência, reflexão totalmente atenuada, reflexão difusa, foto acústica, espalhamento Raman e espectroscopia de infravermelho por transformada de Fourier. Dentre essas técnicas, as que são empregadas na faixa espectral da vibração molecular das células (espalhamento Raman e espectroscopias no infravermelho, por exemplo) fornecem informações sobre a bioquímica celular, identificando marcadores moleculares associados a alterações malignas, benignas ou variações relacionadas à conformação e quantidade de proteínas, lipídeos e outras importantes macromoléculas. [4, 3, 41, 2, 7].

A espectroscopia por transformada de Fourier (FTIR) possui várias vantagens sobre os instrumentos de dispersão [25, 24]: uma vez que não são utilizados monocromadores, a totalidade da faixa de radiação passa simultaneamente pela amostra, gerando um enorme ganho de tempo, além de permitir a utilização de resoluções extremamente altas $\left(\leq 0,001 \mathrm{~cm}^{-1}\right)[25,24]$. Outro ponto interessante a ser ressaltado está relacionado à conversão analógico-digital sofrida pelos dados, através do qual é possível manipulá-los facilmente; com isso, o resultado de várias varreduras é combinado para diminuição do ruído e, bons espectros podem ser obtidos com uma pequena quantidade de amostra $[27,42]$.

A capacidade da espectroscopia por FTIR detectar mudanças com relação a composição bioquímica de células intactas, faz com que a sua utilização na distinção de diversas linhagens celulares seja uma importante ferramenta a ser explorada. 


\subsection{Objetivos}

Estudar um método óptico, baseado na espectroscopia vibracional, visando a caracterização bioquímica de células neoplásicas e sadias.

\subsubsection{Objetivos Específicos}

- Obter os espectros vibracionais de amostras de diversas linhagens celulares;

- Identificar alterações moleculares e bioquímicas, correlacionando-as com as macromoléculas e grupos histológicos aos quais as mesmas pertencem;

- Buscar e classificar diferenças e semelhanças espectrais entre as diversas linhagens; 


\section{Capítulo 3}

\section{Metodologia}

A espectroscopia por FTIR mostrou-se uma poderosa ferramenta no estudo bioquímico de células e tecidos biológicos, permitindo a coleta de informações relacionadas aos diversos bio marcadores, através dos quais é possível estabelecer diferenças entre amostras provenientes de diversas espécies, órgãos ou doenças e ainda, definir alterações bioquímicas ao comparar linhagens neoplásicas e sadias.

Diversos testes foram realizados a fim de se definir as condições ótimas a serem empregadas para a realização das aquisições dos espectros. Tais testes envolveram a definição da janela a ser utilizada, otimização do sinal com relação ao ruído do ambiente, além da verificação da possível interferência de vestígios dos meios de cultura das linhagens celulares. Uma vez que a espectroscopia por FTIR é sensível a diversos compostos.

A análise dos dados foi realizada em três etapas principais, as quais consistiram basicamente na avaliação da variação das áreas referentes às bandas de absorção detectadas; análise do deslocamento dos picos das bandas de absorção e por fim, caracterização mais detalhada de cada uma das linhagens celulares, observando-se a razão relativa de diversos biomarcadores de interesse.

\subsection{Objetos de Estudo: Células}

Neste estudo foram utilizadas oito linhagens celulares distintas, sendo estas agrupadas duas a duas da seguinte maneira: o primeiro grupo foi composto por células provenientes de melanomas humanos e murinos, através do qual caracterizamos e estabelecemos diferenças com relação a linhagens celulares provenientes de duas espécies distintas. O segundo grupo foi composto por células de adenocarcinomas humano (de cólon e de cérvix), ou seja, este foi um grupo formado por duas doenças semelhantes, porém referentes a órgãos distintos. O terceiro grupo estudado foi composto por duas linhagens de câncer de mama humano; as linhagens deste grupo eram extremamente semelhantes, uma vez que ambas eram referentes ao mesmo tipo de câncer, diferindo apenas no fato 
de uma ser receptora de estrogênio negativa e a outra positiva.

Estes três grupos formados podem, por sua vez, ser reagrupados como ćelulas provenientes de tecidos epiteliais. Tal reagrupamento permitiu uma análise mais detalhada, utilizando-se uma avaliação através de razões entre as áreas de diversas bandas de absorção identificadas. De acordo com a variabilidade dos diversos parâmetros, considerados na caracterização das amostras, foi possível efetuar a diferenciação das diversas linhagens celulares estudas.

Finalizando, foram comparadas amostras celulares relativas à leucemia humana do tipo T com células periféricas mononucleares de sangue humano, extraídas de indivíduos saudáveis, a fim de estudar a viabilidade da utilização da espectroscopia por FTIR na diferenciação de células sadias e neoplásicas.

\subsubsection{Linhagens Celulares}

As linhagens tumorais utilizadas neste estudo foram adquiridas da American Type Culture Collection (ATCC, Manassas, VA, USA), com exceção das células mononucleares periféricas de sangue humano (PBMC), as quais foram coletadas de indivíduos saudáveis após a devida aprovação dos procedimentos a serem utilizados, pelo Comitê de Ética em Pesquisa da Faculdade de Ciências Farmacêuticas da USP-RP (carta de aprovação em anexo).

A linhagem de melanoma murino (B16F10) é uma linhagem extraída de camundongos do tipo C57BL/6J [43]. O outro tipo de melanoma estudado foi a linhagem celular denominada C8161, a qual é derivada de uma forma de melanoma subcutâneo agressivo [43]. Estas células possuem uma habilidade única de formação tecidual com aparência vascular, tanto in vivo quanto in vitro.

Outro grupo estudado, foi composto por células derivadas de dois tipos de adenocarcinomas humano: coloretal e de cérvix. A linhagem celular referente ao adenocarcinoma coloretal é denominada HT-29; tal linhagem uma vez que se tratam de células epiteliais do intestino humano, produzem componentes secretórios da imunoglobulina A ( $\lg A)$ e antígenos carcino-embriônicos (CEA) além de possuírem microvilosidades, microfilamentos e grandes mitocôndrias vacuoladas com grãos escuros, retículo endoplásmatico liso e rugoso com ribossomos livres, gotículas lipídicas, e ainda alguns lisossomos primários e muitos secundários [43].

As células do tipo HeLa são uma linhagem celular imortalizada, utilizada em pesquisas médicas. Estas células foram derivadas de um câncer de cérvix de Henrietta Lacks, que faleceu de câncer em outubro de 1951. Tais células possuem uma capacidade de proliferação anormalmente rápida, quando comparada com outras células cancerígenas [43]. Devido a esta favorável adaptação de crescimento em placas de cultura, as células HeLa às vezes são de difícil controle quando utilizadas em certos tipos de experimentos. 
O terceiro grupo estudado, finalizando as linhagens agrupadas no conjunto referente ao tecido epitelial, foi composto por duas linhagens de células de câncer de mama humano. As MCF-7 foram isoladas em 1970 de uma mulher caucasiana de 69 anos de idade. Na primeira de duas mastectomias, o tecido removido possuía alterações de caráter benigno; porém cinco anos mais tarde, durante sua segunda cirurgia, um adenocarcinoma maligno foi encontrado [43].

Durante a remoção dos nódulos da parede peitoral, uma efusão pleural foi descoberta, a partir da qual a linhagem MCF-7 foi derivada. Esta linhagem celular possui diversas características de um epitélio mamário diferenciado, incluindo a habilidade de processar o estradiol por meio de receptores de estrogênio citoplasmáticos $(E R+)$ e capacidade de formação de nódulos [43].

A segunda linhagem de câncer de mama humano utilizada, denominada SKBr3, foi isolada de uma mulher caucasiana de 43 anos de idade. Esta linhagem por sua vez é definida como sendo uma linhagem que não possui receptores de estrogênio (ER-), além de serem células hiper triplóides com 84 cromossomos ocorrendo em cerca de 34\% das células. Esta linhagem celular possui uma composição cromossômica bastante complexa, com marcadores estruturalmente alterados, além de apresentarem microvilosidades, desmossomos, grânulos de glicogênio, grandes lisossomos e feixes de fibras citoplasmáticas [43].

Por fim, foram estudadas células sadias e neoplásicas a fim de verificar a capacidade de diferenciação bioquímica da espectroscopia por FTIR. Nesta etapa, foi utilizada a linhagem celular denominada JURKAT, a qual consiste numa linhagem imortalizada de linfócitos $\mathrm{T}$, comumente adotadas em estudos relacionados à leucemia humana do tipo T. Esta linhagem foi estabelecida no final dos anos 70, derivada de células de sangue periférico de um garoto de 14 anos de idade, portador de leucemia T [43].

As células de sangue periférico humano (PBMC), extraídas de doadores saudáveis, foram utilizadas como referência na comparação com a linhagem relacionada à leucemia. Os doadores foram voluntários, sadios, pertencentes à comunidade da Faculdade de Ciências Farmacêuticas da USP de Ribeirão Preto. Todas as coletas foram devidamente autorizadas, e todos os envolvidos preencheram o Termo de Consentimento Livre e Esclarecido.

As PBMC possuem um núcleo redondo, tal como o de linfócitos ou monócitos. Estas células sangüíneas são um componente crítico do sistema imunológico no combate de infecções. A população de linfócitos consiste basicamente em células do tipo T, do tipo B e macrófagos. Essas células são freqüentemente extraídas do sangue, utilizando-se o Ficoll, um polissacarídeo hidrofílico que separa as camadas de sangue, através de um procedimento que será descrito na seção 3.1.2. 


\subsubsection{Cultura Celular}

A cultura celular realizada neste estudo foi conduzida através do seguimento de protocolos padrões. O meio de cultura utilizado para as linhagens B16F10, C8161, JURKAT, MCF-7 e SKBr3 foi o RPMI 1640 sem vermelho de fenol suplementado (RPMI-S) com $10 \%$ de soro bovino fetal, $20 \mathrm{~m} M$ de L-glutamina, $2 g / l$ de bicarbonato de sódio, $2,38 \mathrm{~g} / \mathrm{l}$ de solução tampão HEPES, $100 \mathrm{U} / \mathrm{ml}$ penicilina e $100 \mathrm{mg} / \mathrm{ml}$ estreptomicina (GibcoIvitrogen, Carlsbad, CA).

Para as linhagens HeLa e HT-29 foi utilizado o meio de cultura Dulbecco's sem vermelho de fenol suplementado (Dulbeccos-S) com 10\% de soro bovino fetal, $20 \mathrm{mM}$ de L-glutamina, $3,7 \mathrm{~g} / \mathrm{l}$ de bicarbonato de sódio, $100 \mathrm{U} / \mathrm{ml}$ penicilina e $100 \mathrm{mg} / \mathrm{ml}$ estreptomicina (Gibco-Invitrogen, Carlsbad, CA). As células foram incubadas em estufa umidificada contendo $95 \%$ de ar e $5 \%$ de $\mathrm{CO}_{2}$ a $37^{\circ} \mathrm{C}$.

As linhagens B16F10, C8161, HT-29, MCF-7 e SKBr3 eram do tipo aderentes. As células foram removidas dos frascos de cultivo celular através da adição de $0,2 m l$ de solução de tripsina-EDTA $(2.5 \mathrm{~g} / \mathrm{l}$ ) (Sigma-Aldrich, St. Louis, MO, USA), e posteriormente, lavadas três vezes em meio RPMI-S a 1000rpm por 15 minutos.

Para a realização dos experimentos as células foram lavadas três vezes em solução salina a 1000rpm por 15 minutos, a fim de garantir que o meio de cultura fosse removido.

Após as lavagens, as células foram contadas através de uma câmara de Neubauer (hemocitômetro), suspensas em solução salina na concentração de cerca de $10^{7}-10^{8}$ células a cada $10 \mu \mathrm{L}$. Um esquema ilustrando o procedimento básico adotado durante a etapa referente à cultura celular é apresentado na figura 3.1.

As PBMC foram coletadas do sangue de doadores voluntários humanos saudáveis em tubos heparinizados a fim de impedir a coagulação sangüínea. O sangue coletado foi diluído na proporção de 1:1 em meio RPMI incompleto (RPMI-I) e homogeneizado por inversão.

Posteriormente, uma amostra contendo Ficoll-Hypaque (Histopaque-1077 - Sigma Diagnostics, Inc., Missouri, USA) e a solução contendo sangue e RPMI-I, na proporção de 1:2, foi preparada. Tendo em vista que a separação dos componentes do sangue ocorre através de um gradiente de densidades, primeiramente o Ficoll foi adicionado a um tubo do tipo falcon e, posteriormente, adicionada a solução de sangue e RPMI-I. Este procedimento visa evitar a mescla do Ficoll com a solução de maneira errônea, comprometendo a separação. 


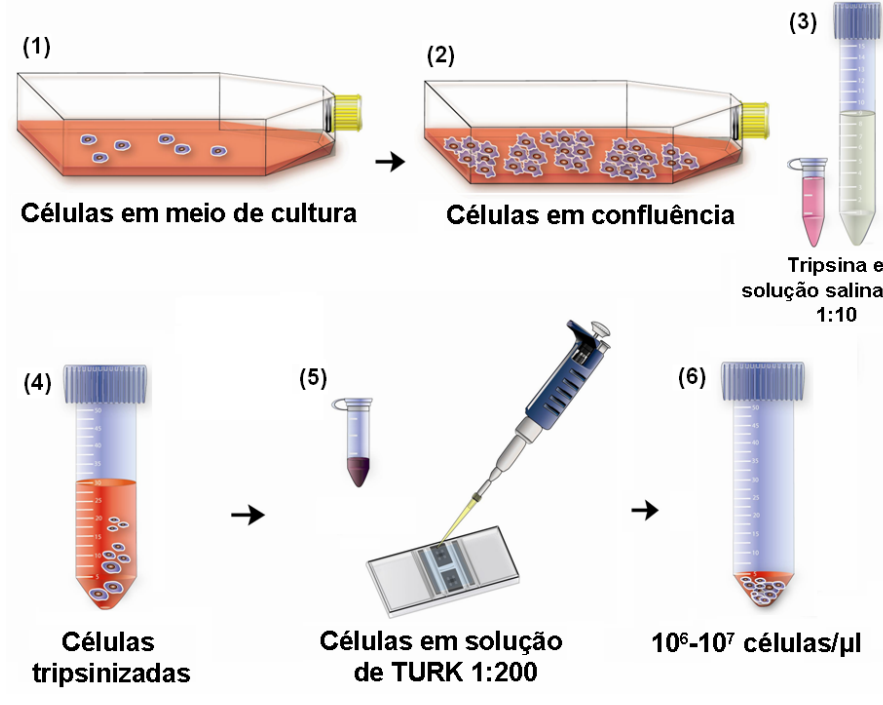

Figura 3.1: Esquema ilustrativo de parte do procedimento adotado nas culturas celulares. As células foram mantidas em garrafas de cultura; uma vez atingida a confluência, as mesmas foram retiradas das garrafas (através da utilização da tripsina, no caso das linhagens aderentes), mescladas a uma solução de TURK para que as mesmas fossem contadas num hemocitômetro.

Através da centrifugação a $3000 \mathrm{rpm}$, por 30 minutos à $25^{\circ} \mathrm{C}$, um gradiente de densidade conforme apresentado na figura 3.2, foi formado tornando possível a obtenção das PBMC, uma vez que estas formam um anel entre o plasma sangüíneo e o Ficoll. As células foram separadas das hemácias e do plasma e retiradas com a ajuda de uma pipeta.

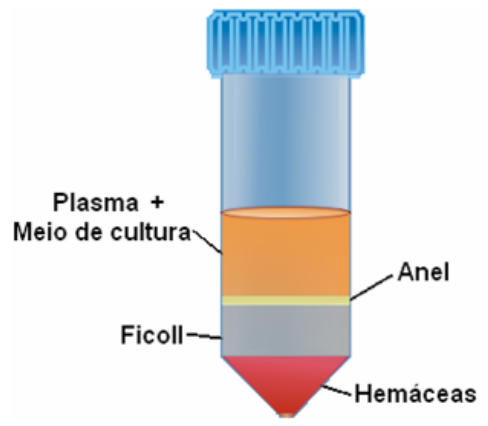

Figura 3.2: Gradiente de densidade formado através da utilização do Ficoll, para separação dos componentes do sangue. As PBMC formam um anel situado entre o plasma sangüíneo e o Ficoll.

As células mononucleares foram lavadas uma vez, com meio de cultura RPMI-S, a $1200 \mathrm{rpm}$ por 20 minutos à $10^{\circ} \mathrm{C}$ e duas vezes a $1000 \mathrm{rpm}$ por 15 minutos à $10^{\circ} \mathrm{C}$. Por fim, a exemplo do realizado com as demais linhagens, as PBMC foram lavadas três vezes em solução salina a 1000rpm por 15 minutos, visando a máxima eliminação possível do meio de cultura. 
Após as lavagens, as células foram contadas em um hemocitômetro, suspensas em solução salina, novamente na concentração de $10^{7}-10^{8}$ células a cada $10 \mu \mathrm{L}$ e, posteriormente centrifugadas 1000rpm por 15 minutos para que um "pellet" fosse formado no fundo do tubo, facilitando assim a extração das células para a realização dos experimentos.

Finalizada a fase de preparação, as células foram depositadas em janelas de $\mathrm{CaF}_{2}$ (descritas na seção 3.2.2). Uma vez que as mesmas encontravam-se imersas em solução salina, e as moléculas de água absorvem a radiação na região do infravermelho, foi necessário secá-las utilizando-se um jato de nitrogênio por cerca de 10 minutos.

\subsection{Espectroscopia por FTIR}

Previamente à realização das medições, diversos testes foram conduzidos a fim de se estabelecer a melhor metodologia a ser empregada, definindo-se uma metodologia para a aquisição de dados (passo, resolução, etc), assim como avaliar os efeitos de fatores externos, tais como influência do ambiente (umidade e presença de moléculas de $\mathrm{CO}_{2}$ ), definição da janela a ser empregada e eventual detecção do sinal referente ao meio de cultura o qual as células encontravam-se imersas.

\subsubsection{Teste do Sinal vs. Ruído do Ambiente}

O ambiente está preenchido com moléculas de $\mathrm{CO}_{2}$ e água $\left(\mathrm{H}_{2} \mathrm{O}\right)$, cuja concentração sofre variação de acordo com a umidade relativa do ar. Ambas as moléculas possuem ligações do tipo covalente, ou seja, vibram ao serem excitadas pela radiação infravermelha, exibindo bandas de absorção no espectro a ser estudado.

Para otimizar o sinal da amostra com relação ao ruído do ambiente, foi anexado ao aparelho um sistema de purificação e desumidificação do fluxo de ar injetado no compartimento das amostras do espectrômetro.

Este sistema foi constituído primeiramente de um purificador de ar comercial, da marca Hyperfilter light, conectado seguidamente a um secador de ar comprimido da marca Metaplan, modelo Airpoint, especificado segundo o padrão ISO-8573. Além do purificador e secador de ar, foi acoplado ao sistema de ar comprimido uma mangueira de $100 \mathrm{~cm}$, contendo grãos de sílica gel (4/8mm P.A., Synth) com capacidade de adsorção mínima de 20\%, a fim de reduzir ao máximo a umidade do ar injetado no compartimento das amostras.

A redução do sinal referente ao $\mathrm{CO}_{2}$ foi realizada com um sistema de purga, através do fechamento do compartimento da amostra por um certo intervalo de tempo definido posteriormente, imerso num fluxo contínuo de ar seco.

Foram realizados diversos testes com o intuito de encontrar um tempo ótimo de 
redução do $\mathrm{CO}_{2}$, uma vez que por se tratar de amostras biológicas as quais estão sujeitas à diversos efeitos, tal como a desnaturação das proteínas, quanto menor o tempo necessário para a redução do ruído ambiental, mais satisfatórias são as condições.

Além do tempo de imersão da amostra no fluxo de ar, foram efetuados testes variandose a resolução e o passo com que os dados eram adquiridos, a fim de se determinar a melhor condição experimental, uma vez que ao aumentarmos a resolução ou o passo, o tempo de aquisição dos dados também sofre variação, novamente estando relacionado a um possível grau de degradação da amostra.

Na figura 3.3 são apresentados os gráficos referentes aos testes realizados. O primeiro teste (figura 3.3(a)) foi realizado utilizando-se uma resolução de 32 scans com um passo de $2 \mathrm{~cm}^{-1}$; foi variado o tempo de imersão da amostra no fluxo de ar, adquirindo-se espectros após 1 minuto de imersão, 3 minutos e 6 minutos.

A banda de absorção localizada em cerca de $2400 \mathrm{~cm}^{-1}$ é referente às vibrações das moléculas de $\mathrm{CO}_{2}$ do ambiente, e as bandas existentes nas regiões próximas a $1600 \mathrm{~cm}^{-1} \mathrm{e}$ $3800 \mathrm{~cm}^{-1}$ são referentes, basicamente, aos modos vibracionais e rotacionais das moléculas de água do ar.

Na figura 3.3(b) é mostrado o resultado para o segundo teste realizado; desta vez, o espectro foi adquirido utilizando-se um passo de $4 \mathrm{~cm}^{-1}$ e 32 scans. Os tempos de imersão no fluxo de ar, antes da aquisição dos espectros foram 1 minuto, 3 minutos, 6 minutos e 10 minutos. Nas figuras 3.3(c) e 3.3(d) são apresentados os resultados dos demais testes, os quais foram realizados mantendo-se os tempos de imersão no fluxo de ar citados anteriormente, variando-se apenas o passo e a resolução que foram 32 scans com $6 \mathrm{~cm}^{-1}$ e 64 scans com $2 \mathrm{~cm}^{-1}$, respectivamente.

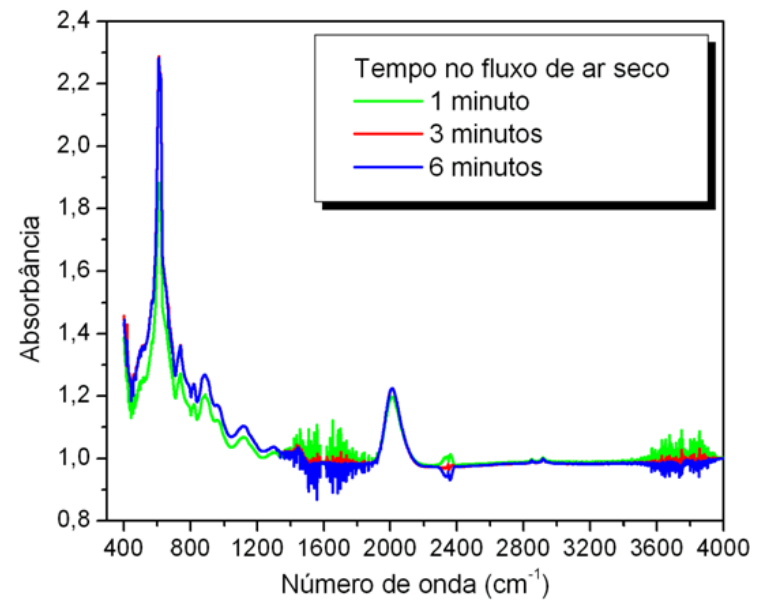

(a) Resolução 32 , passo $2 \mathrm{~cm}^{-1}$

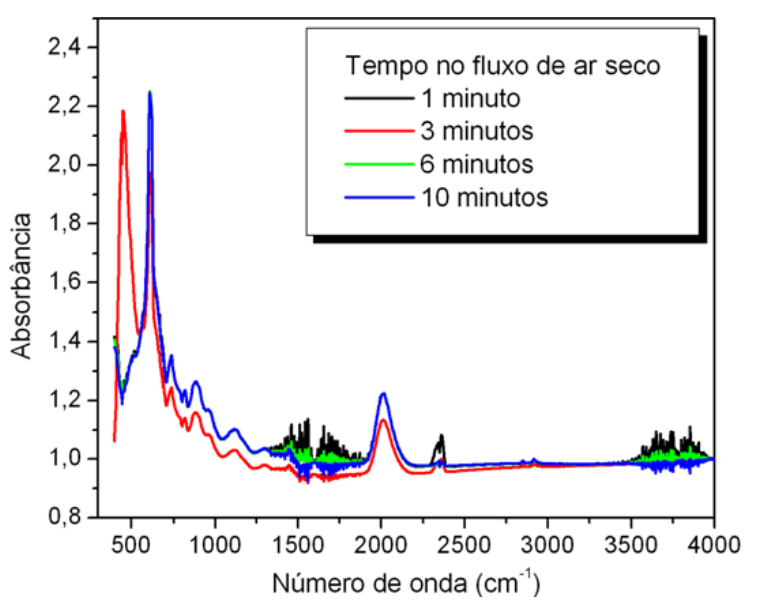

(b) Resolução 32 , passo $4 \mathrm{~cm}^{-1}$ 


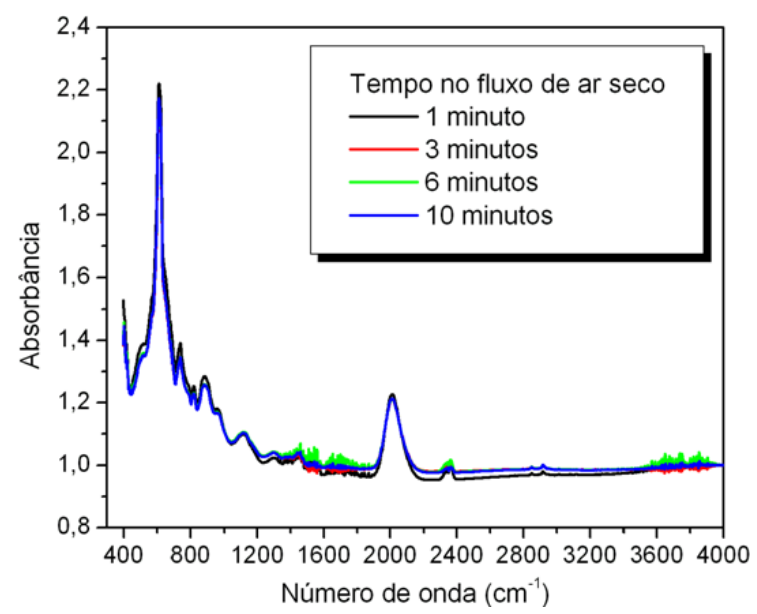

(c) Resolução 32 , passo $6 \mathrm{~cm}^{-1}$

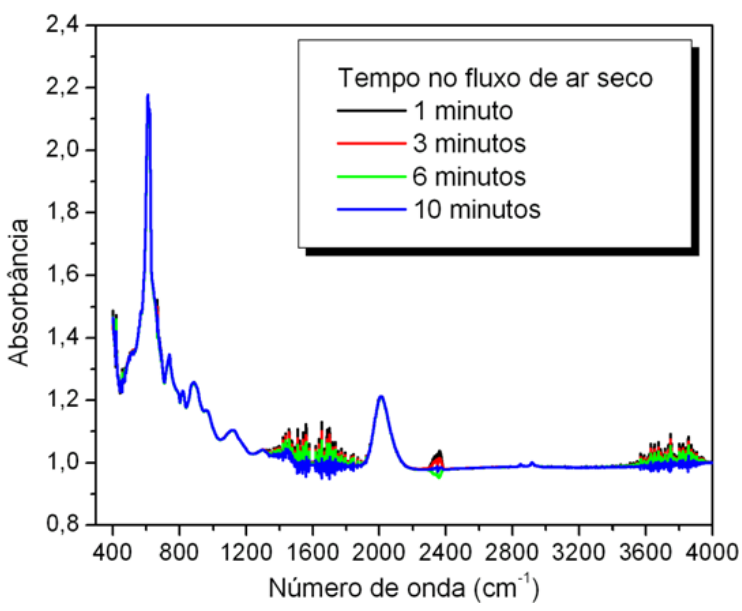

(d) Resolução 64, passo $2 \mathrm{~cm}^{-1}$

Figura 3.3: Teste de verificação dos efeitos de alterações na resolução e passo de aquisição dos dados, assim como variação do tempo de imersão da amostra no fluxo de ar seco. A banda de absorção das moléculas de $\mathrm{CO}_{2}$ está situada na região de $2400 \mathrm{~cm}^{-1}$, ao passo que as bandas referentes à absorção das moléculas de água estão localizadas nas regiões próximas a $1600 \mathrm{~cm}^{-1}$ e $3800 \mathrm{~cm}^{-1}$. Na figura 3.3(a) são apresentados os espectros adquiridos com resolução 32 e de passo $2 \mathrm{~cm}^{-1}$; na figura $3.3(\mathrm{~b})$, são apresentados os espectros com resolução 32 e passo $4 \mathrm{~cm}^{-1}$; na figura $3.3(\mathrm{c})$ e $3.3(\mathrm{~d})$ observamos os espectros adquiridos com resolução de 32 e passo $6 \mathrm{~cm}^{-1}$, resolução 64 e passo $2 \mathrm{~cm}^{-1}$, respectivamente.

A metodologia escolhida para a realização dos experimentos foi a utilização de um passo de $4 \mathrm{~cm}^{-1}$, com 32 repetições, mantendo-se a amostra imersa no fluxo de ar ao longo de 10 minutos. Esta foi a combinação escolhida levando-se em consideração os seguintes fatores: ao adquirirmos espectros com uma passo de $6 \mathrm{~cm}^{-1}$ alguns detalhes possivelmente relevantes podem ser perdidos, por outro lado, a aquisição com $2 \mathrm{~cm}^{-1}$ não apresentou alterações significativas quando comparada com a aquisição realizada com um passo de $4 \mathrm{~cm}^{-1}$. O teste realizado com 64 repetições, foi o mais longo (levando cerca de 5 minutos para a a aquisição ser finalizada, enquanto a aquisição com 32 repetições dura cerca de 2 minutos), sendo desta forma descartado, uma vez que conforme citado anteriormente, por se tratar de amostras biológicas, quanto menor o tempo para a aquisição do espectro, menos a amostra será degradada. Por fim, o tempo de imersão da amostra no fluxo de ar para redução do $\mathrm{CO}_{2}$ foi definido baseado na redução da intensidade de absorção da banda referente ao mesmo.

\subsubsection{Janela de $\mathrm{CaF}_{2}$}

As janelas a serem empregadas devem satisfazer uma série de requisitos, dentre eles, as mesmas devem ser quimicamente inertes, transparentes aos fótons com energia na região do infravermelho, utilizáveis a temperaturas relativamente altas $\left(250^{\circ} \mathrm{C}\right)$, duras 
(resistentes à abrasão), além de serem compostas de materiais os quais possuam uma capacidade de durar longos períodos sem sofrer degradação. [20, 44]

Uma janela de transmissão adequada deve ser capaz de transmitir a radiação com números de onda baixos, ou seja, transmitir a maior parte da radiação na região referente à impressão digital do espectro. Janelas de fluoreto de cálcio $\left(\mathrm{CaF}_{2}\right)$ possuem um índice de refração de $1,399 \mathrm{em} 2000 \mathrm{~cm}^{-1}$ e transmissão na região de $50000-900 \mathrm{~cm}^{-1}$, conforme podemos observar na figura 3.4. [45]

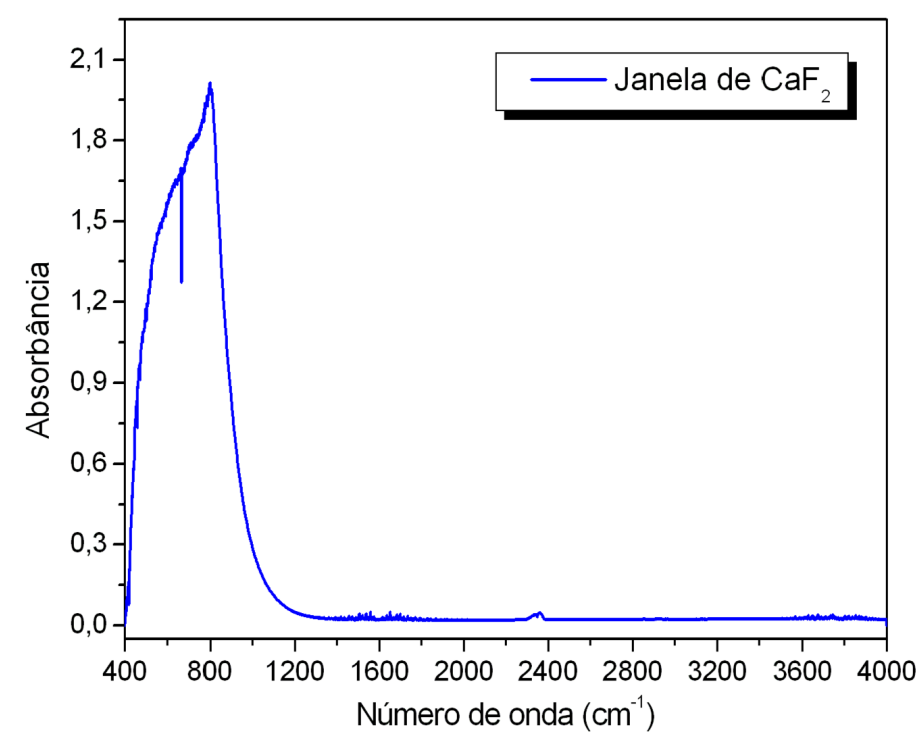

Figura 3.4: Espectro de absorção da janela de $\mathrm{CaF}_{2}$ utilizada neste trabalho; sendo a mesma transparente na região espectral de interesse, situada entre $950 \mathrm{~cm}^{-1}$ e $4000 \mathrm{~cm}^{-1}$.

Desta forma, neste trabalho foram utilizadas cinco janelas de $\mathrm{CaF}_{2}$ idênticas, cujas dimensões eram de $2,54(2) \mathrm{cm}$ de diâmetro e $0,50(2) \mathrm{cm}$ de espessura.

\subsubsection{Teste de Sinal dos Meios de Cultura}

As células foram mantidas em meios de cultura (RPMI-S e Dulbeccos-S). Uma vez que os meios de cultura são compostos quimicamente complexos, a fim de eliminar a detecção de bandas não referentes às amostras estudadas, as células foram lavadas com solução salina antes de serem depositadas nas janelas de transmissão. Foram realizados testes para verificação do espectro de tais meios, além do espectro de absorção da solução salina.

Uma amostra de cada um dos meios de cultura e uma amostra da solução salina foram depositada nas janelas de $\mathrm{CaF}_{2}$, secadas com nitrogênio, realizando-se um procedimento análogo ao que seria realizado na aquisição de dados das amostras. Os espectros foram adquiridos com um passo de $4 \mathrm{~cm}^{-1}, 32$ repetições, além das janelas terem sido imersas 
no fluxo de ar, por 10 minutos, previamente à aquisição dos mesmos; os espectros obtidos são apresentados na figura 3.5.

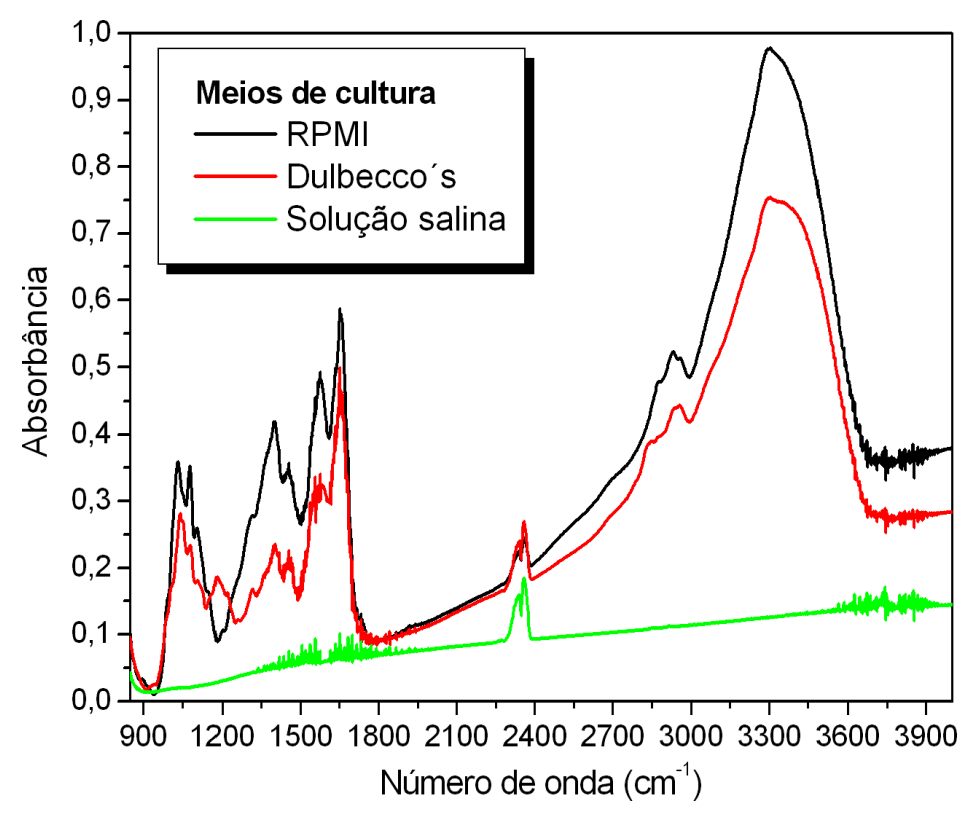

Figura 3.5: Espectros de absorção dos meios de cultura utilizados nas culturas celulares. Tais meios, por se tratarem de compostos químicos complexos, possuem bandas de absorção situadas na região de interesse; porém, observando-se o espectro de absorção da solução salina, é possível verificar a ausência de bandas de absorção na região de interesse, confirmando que a mesma pode ser utilizada de maneira satisfatória na lavagem das células, previamente à realização dos experimentos.

É possível verificar que, embora os meios de cultura apresentem bandas de absorção na região espectral analisada, a solução salina após ser secada com nitrogênio, não absorve na região do infravermelho uma vez que apenas foi possível detectar bandas referentes às moléculas de $\mathrm{CO}_{2}$ e algum ruído referente a moléculas de água. Desta forma, consideramos que após as lavagens, o sinal adquirido foi referente apenas às linhagens celulares estudadas.

\subsection{Análise dos dados}

Foram replicadas cinco amostras de cada linhagem celular e os espectros adquiridos foram analisados em três etapas. Na primeira, foram estudadas as áreas referentes a cada uma das bandas de absorção, integrando-se as mesmas com o auxílio do programa "Microcal Origin 6.0".

Todos os espectros foram normalizados pela área da banda situada em $1240 \mathrm{~cm}^{-1}$ (estiramento assimétrico do $\mathrm{PO}_{2}$ ), pois ao depositarmos as células nas janelas, um filme foi formado. Estes filmes possuíam espessura distintas, conseqüentemente, continham 
quantidades de compostos diferentes. Uma vez que visamos a determinação de ligações químicas referentes a determinadas macromoléculas existentes nas células, essa normalização foi necessária.

Na literatura, a banda localizada na região de $1650 \mathrm{~cm}^{-1}$ (referente à amida I), é largamente utilizada como referência para a realização desta normalização $[46,7,47,2,4]$. Neste trabalho, a banda referente à amida I não foi adotada na normalização, uma vez que esta molécula é sensível a diversos fatores como por exemplo a desnaturação, que pode ocorrer após a secagem das amostras. Sendo assim, a banda referente à amida I sofre descolamentos e mudanças com relação à forma da curva, não sendo portanto uma boa referência a ser adotada na normalização de todo o espectro [48, 49, 50].

Uma vez descartada a adoção da banda da amida I, foi necessária a definição de outra banda de referência. Amostras biológicas são ricas em compostos os quais contêm ligações com o átomo de carbono (por exemplo, C-H, C-O, C-C, etc). Estes compostos de carbono estão presentes em praticamente todas as macromoléculas biológicas, em diferentes quantidades. Para a realização da normalização, visamos utilizar uma banda que fosse estável, que não sofresse degradação ao ser exposta ao ambiente (como a secagem, por exemplo) e o mais específica possível, ou seja, pertencente à menor quantidade de estruturas celulares possíveis.

Analisando-se a composição celular geral [32], notou-se que as ligações contendo o fosfato encontravam-se somente nas moléculas dos ácidos nucléicos e nas moléculas de fosfolipídeos e fosfoproteínas. A maior parte destas ligações são referentes ao DNA e RNA, que por sua vez são macromoléculas estáveis o suficiente para suportar o procedimento de secagem da amostra sem sofrer alterações apreciáveis em sua estrutura. Com isto, definimos a banda localizada em $1240 \mathrm{~cm}^{-1}$ como referência para a normalização espectral.

Após a normalização e integração de cada banda do espectro, foi calculada uma média aritmética das áreas de cada banda, para cada uma das linhagens celulares; para identificação de semelhanças e diferenças entre os grupos, foi realizado o teste t de Student, com intervalo de rejeição de $p<0,05$.

A segunda etapa da análise consistiu na avaliação das derivadas de segunda ordem do espectro de absorção. Tal cálculo, evidencia as posições das bandas de absorção; o cálculo das derivadas de primeira ordem, enfatizam as larguras das bandas de absorção, uma vez que o perfil geral das bandas possui pontos de máximo e mínimo próximos aos pontos situados à meia altura; sendo assim, todas as derivadas reduzem ou eliminam os efeitos da linha de base e de fundo, sendo por este motivo frequentemente utilizadas na espectroscopia [45].

Através do cálculo destas derivadas, foi possível verificar eventuais deslocamentos dos picos das bandas de absorção, através dos quais visamos identificar alterações estruturais das macromoléculas constituintes das células. 
Finalmente, outro ponto abordado na análise dos espectros foi a análise de razões. Esta análise foi realizada adotando-se uma banda de absorção como referência para cada grupo molecular: as variações associadas ao DNA foram estudadas considerando-se a área da banda de absorção localizada em $1084 \mathrm{~cm}^{-1}$; com relação ao RNA, a banda de absorção considerada foi aquela situada em $1120 \mathrm{~cm}^{-1}$ a região das proteínas foi representada pelas bandas localizadas em $1650 \mathrm{~cm}^{-1}$ e $1540 \mathrm{~cm}^{-1}$ e a região dos lipídeos pela banda em $1740 \mathrm{~cm}^{-1}$.

No caso do DNA, foi considerada a banda referente aos modos vibracionais das ligações fosfato simétrico, pois tal ligação é encontrada de maneira abundante nesta macromolécula. No caso do RNA, a banda de absorção escolhida é referente ao estiramento simétrico das moléculas de $\mathrm{C}-\mathrm{N}$ e $\mathrm{C}-\mathrm{C}$. As proteínas foram representadas pelas bandas de absorção referentes à amida I e amida II, pois estas bandas são comumente utilizadas como referências às proteínas em diversos trabalhos [46, 47]; e por fim, para representação dos lipídeos, foi escolhida a banda referente ao sebo, uma vez que esta banda é a que apresenta menor interferência da absorção de moléculas das proteínas $[40,51]$.

Uma vez definidas quais bandas seriam representativas da variabilidade da quantidade de ligações referentes à cada um dos grupos representantes das macromoléculas existentes nas células, foram calculadas razões entre tais áreas. As razões consideradas foram referentes à amida I/amida II, DNA/RNA, amida I/DNA e proteínas/lipídeos. Através da análise destas razões, buscou-se diferenciar as diversas linhagens celulares estudadas. 


\section{Capítulo 4}

\section{Resultados e Discussões}

As linhagens celulares estudadas foram agrupadas conforme descrito na seção 3.1. O estudo foi realizado em seis etapas: a primeira consistiu na caracterização e diferenciação de células referentes à mesma doença, porém provenientes de espécies distintas (melanoma humano e murino); a segunda etapa consistiu no estudo de células de uma doença semelhante, porém proveniente de órgãos distintos (adenocarcinoma de cérvix e de cólon).

Na terceira etapa, foi realizada a diferenciação de células as quais possuíam apenas características bioquímicas distintas (câncer de mama com receptores de estrogênio positivo e negativo); a quarta etapa consistiu na comparação e caracterização de dois tipos de células, sendo uma neoplásica e a outra sadia (leucemia tipo T e linfócitos T)

$\mathrm{Na}$ quinta parte deste trabalho foram comparadas entre si as linhagens celulares citadas anteriormente através da análise de razões entre diversos bio marcadores. Por fim, na sexta e última etapa, é apresentada uma discussão com relação às alterações espectrais observadas na região referente às bandas de absorção das amidas.

Um espectro no infravermelho típico das amostras estudadas neste trabalho, referente à linhagem de celular de melanoma humano (C8161), é apresentado na figura 4.1, como exemplo. Os espectros são apresentados em função da absorbância e números de onda entre $4000-900 \mathrm{~cm}^{-1}$.

É possível observar bandas de absorção correspondentes aos lipídeos (entre 3100 $2800 \mathrm{~cm}^{-1}$ ), proteínas (entre $1700-1450 \mathrm{~cm}^{-1}$ ) e DNA (entre $1300-900 \mathrm{~cm}^{-1}$ ). A presença de bandas referentes a estas macromoléculas é observada em todas as linhagens celulares estudadas, com uma razão sinal/ruído satisfatória.

Uma vez que o perfil espectral observado é semelhante para todas as amostras celulares estudadas, a apresentação e análise dos espectros de absorção de todas as linhagens será realizada nesta seção, restando apenas a apresentação e discussão dos resultados específicos para cada grupo, para as seções posteriores. 


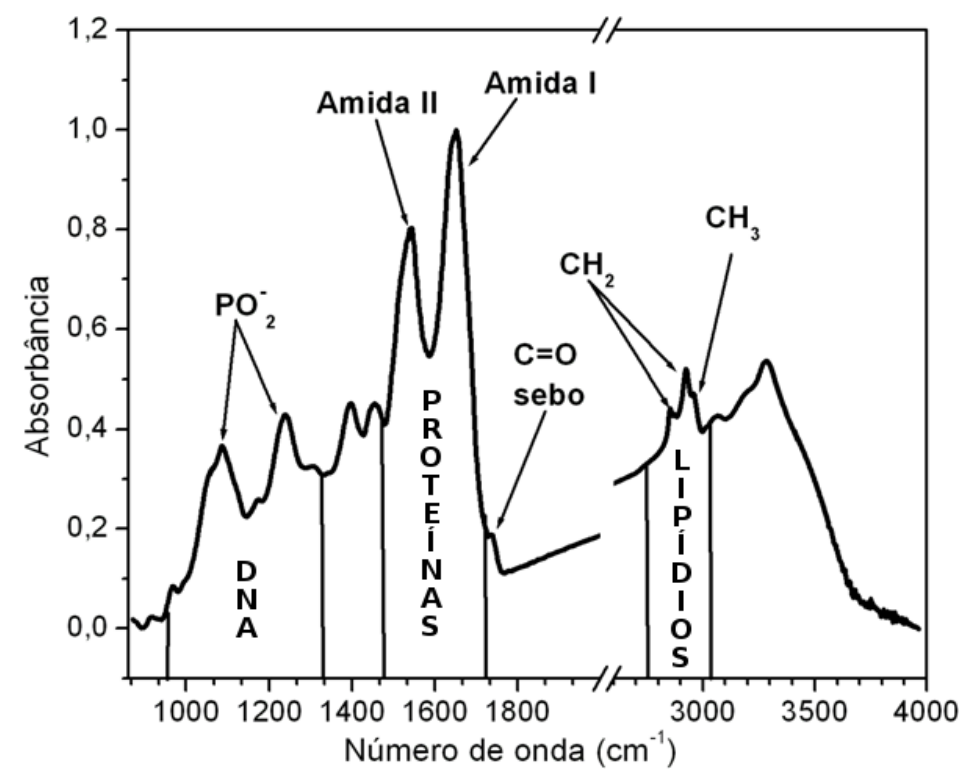

Figura 4.1: Espectro de absorção típico das amostras estudadas; neste caso, é apresentado um espectro de melanoma. Para facilitar a caracterização das bandas identificadas, foi proposta a divisão espectral apresentada, onde a maioria das bandas de absorção referentes ao DNA estão situadas na região de $900-1300 \mathrm{~cm}^{-1}$; as bandas referentes às proteínas encontram-se na região $1450-1700 \mathrm{~cm}^{-1}$ e às bandas referentes aos lipídeos situam-se em torno de $2800-3100 \mathrm{~cm}^{-1}$.

Na figura 4.2 são apresentados os espectros de absorção obtidos para cada uma das linhagens celulares estudadas. A banda mais intensa está relacionada à amida I, centrada aproximadamente em $1640 \mathrm{~cm}^{-1}$, a qual corresponde aos modos vibracionais de estiramento $(\nu)$ do $\mathrm{C}=\mathrm{O}$ acoplado aos modos de flexão $(\delta)$ da molécula de $\mathrm{N}-\mathrm{H}$ e estiramento da molécula de $\mathrm{C}-\mathrm{N}$ das ligações peptídicas $[2,41]$.

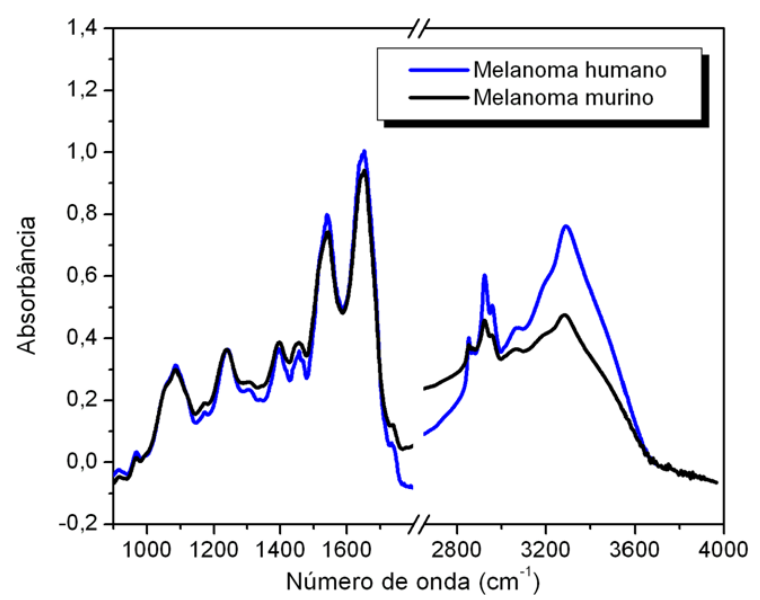

(a) Melanoma humano e murino

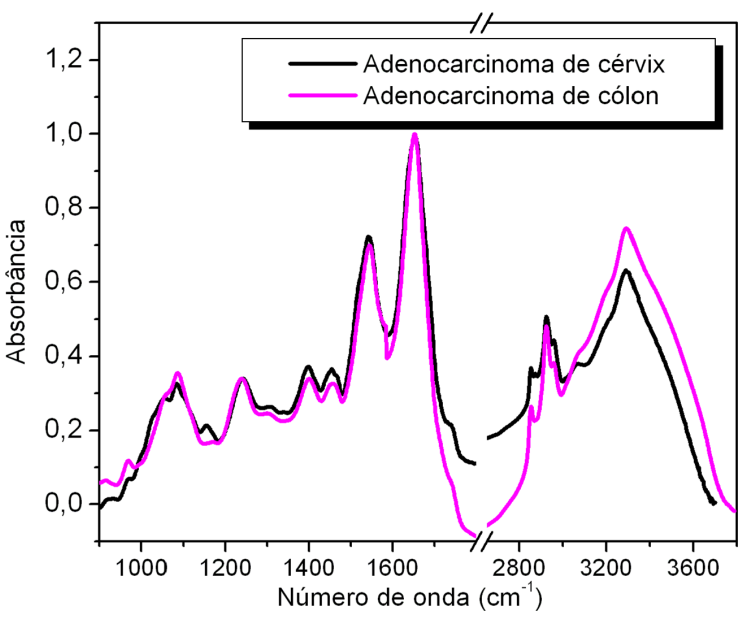

(b) Adenocarcinoma de cérvix e de cólon 


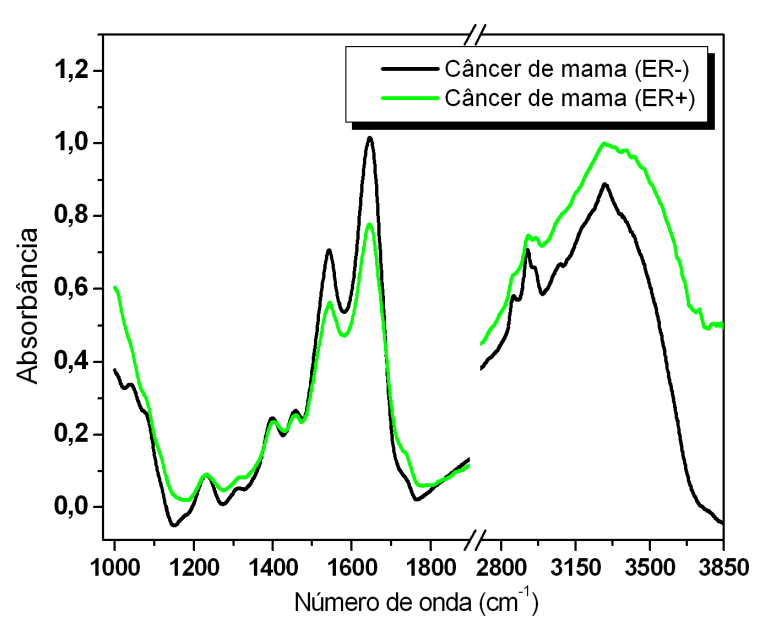

(c) Câncer de mama com ER+ e ER-

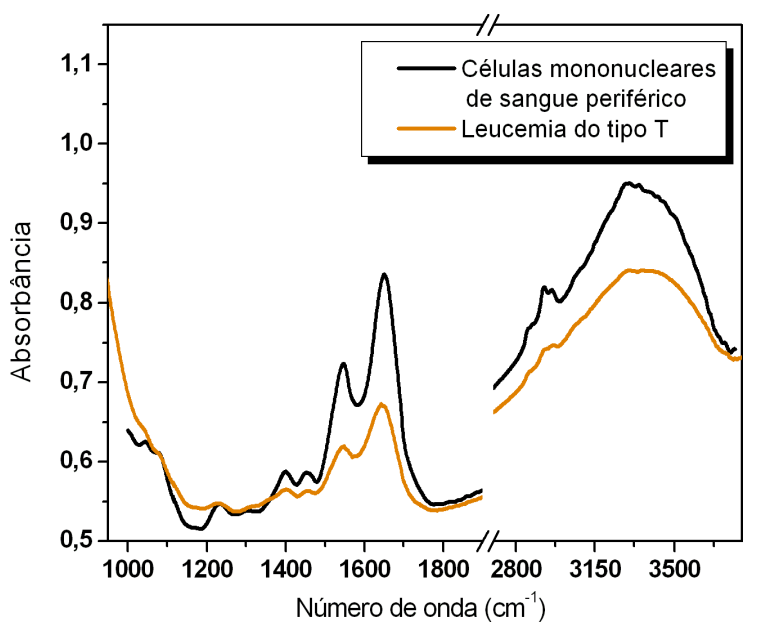

(d) Leucemia tipo $\mathrm{T}$ e células periféricas mononucleares humanas

Figura 4.2: Espectros de absorção médios obtidos para cada linhagem estudada. Todos os espectros são apresentados normalizados pela área da banda de absorção localizada na região de $1238 \mathrm{~cm}^{-1}$, sendo esta associada ao estiramento $(\nu)$ assimétrico da molécula de $\mathrm{PO}_{2}$, contida nas ligações fosfodiéster do DNA. Na figura 4.2(a) são apresentados os espectros de absorção referentes aos melanomas humano e murino; na figura 4.2(b) são apresentados os espectros referentes aos adenocarcinomas de cérvix e cólon; na figura 4.2(c) são apresentados os espectros das linhagens de cânceres de mama e na figura 4.2(d), observamos os espectros de absorção dos linfócitos $\mathrm{T}$ e da linhagem de leucemia tipo T humana.

A segunda banda, centrada próxima à $1540 \mathrm{~cm}^{-1}$, corresponde ao modo de estiramento da molécula de amida II $[2,41]$. De acordo com a literatura, as posições das bandas referentes à amida I e amida II são indicativas da estrutura das proteínas [2, 46, 48, 49].

Na região compreendida entre $1646-1655 \mathrm{~cm}^{-1}$, referente à amida I, as bandas de absorção são associadas à conformação das proteínas; a banda situada em cerca de $1646 \mathrm{~cm}^{-1}$ está relacionada à configuração beta, ao passo que a banda situada em cerca de $1652 \mathrm{~cm}^{-1}$ está relacionada à estrutura alfa hélice das proteínas [46, 2]. Uma discussão com relação às alterações verificadas nesta região será apresentada na seção 4.5.

A banda de absorção localizada próxima a $1309 \mathrm{~cm}^{-1}$ é atribuída à amida III, outra componente das proteínas. Na região compreendida entre $1300-1000 \mathrm{~cm}^{-1}$, as principais características espectrais observadas são as vibrações relacionadas ao estiramento das moléculas de $\mathrm{PO}_{2}$ dos ácidos nucléicos e vibrações do tipo estiramento das moléculas de C-O dos resíduos de carboidratos, contidos no glicogênio [2, 41, 3, 4].

Finalmente, podemos associar a região espectral situada entre $\left(2800-3100 \mathrm{~cm}^{-1}\right)$ aos lipídeos; a banda centrada em cerca de $2851 \mathrm{~cm}^{-1}$ corresponde ao estiramento simétrico das ligações $\mathrm{C}-\mathrm{H}$, presentes em moléculas de $\mathrm{CH}_{2}$, as quais são componentes dos ácidos graxos. O estiramento assimétrico destas moléculas é evidenciado pela banda localizada em cerca de $2921 \mathrm{~cm}^{-1}$. A região compreendida entre $3060 \mathrm{~cm}^{-1}$ e $3185 \mathrm{~cm}^{-1}$ é associada 
ao estiramento das ligações $\mathrm{C}=\mathrm{C}-\mathrm{H}[2,3,4]$.

Na seção 4.1 serão apresentados e discutidos os resultados referentes às linhagens de melanomas murino e humano, na seção 4.2 serão apresentados os resultados referentes aos adenocarcinomas de cérvix e cólon; na seção 4.3 e na seção 4.4,serão apresentados e discutidos os resultados referentes as linhagens de cânceres de mama, assim como linfócitos T e leucemia tipo $\mathrm{T}$ humana, respectivamente.

\subsection{Melanoma Humano vs. Melanoma Murino}

De acordo com a Sociedade Americana do Câncer, o câncer de pele é um dos tipos mais comuns entre os seres humanos, correspondendo a cerca de $18 \%$ dos casos diagnosticados no ano de 2008 [52].

A grande maioria dos cânceres de pele são compostos por carcinomas baso celulares e carcinomas espinocelulares; porém, o tipo mais agressivo é o melanoma [52, 37]. Melanomas são lesões pigmentadas na pele, os quais geralmente aparecem em áreas expostas à radiação solar [37, 53].

Estudos epidemiológicos têm sugerido que a exposição à radiação ultravioleta (UVA e UVB) exerce um papel chave no desenvolvimento de melanomas [37, 53]. A radiação UV pode causar danos ao DNA, como por exemplo, a dimerização da timina, a qual é uma das responsáveis pela ocorrência de mutações nos genes celulares [37]. Caso estes danos não sejam reparados quando as células sofrerem a divisão celular, estas mutações serão propagadas para as novas gerações. Se as mutações ocorrerem em oncogenes ou em genes supressores de tumores, a taxa mitótica (devido a efeitos relacionados à mutação da célula) pode apresentar descontrole, acarretando na formação de tumores [37]. O câncer de pele pode ter várias causas, incluindo queimaduras solares repetidas ou longos períodos de exposição ao sol [53].

A característica mais comum referente aos diversos tipos de melanomas é a presença de alterações nas nevus. Alguns estudos têm sido conduzidos visando uma maneira de diagnosticar e realizar um combate eficaz a estas doenças [54, 55], sendo a espectroscopia por FTIR uma ferramenta promissora nesta busca [56, 40, 51].

Na figura 4.3 é apresentado um esquema das camadas básicas da pele humana; o câncer de pele geralmente se desenvolve na epiderme, sendo esta a camada mais externa da mesma. Desta forma, a maioria dos casos de câncer de pele podem ser detectáveis nos seus estágios iniciais. 


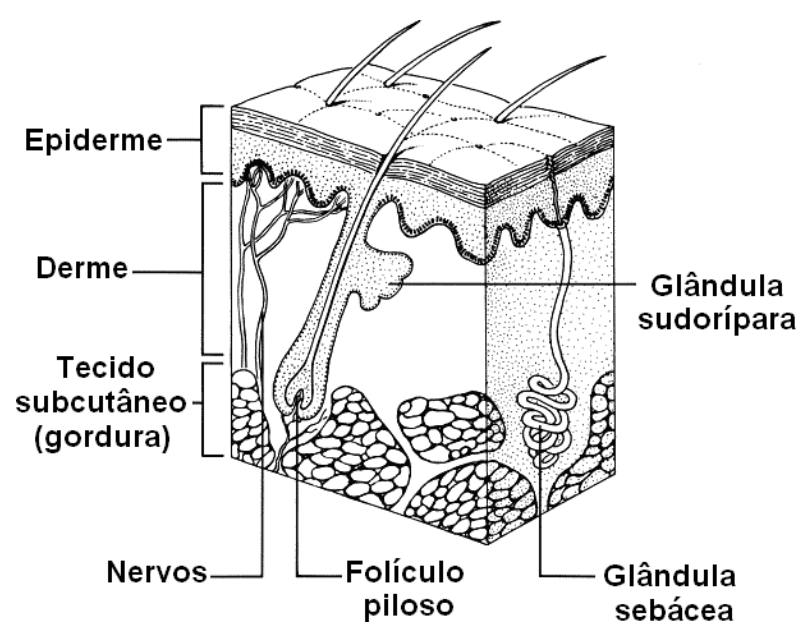

Figura 4.3: Esquema simplificado da pele humana. As principais camadas que compõem a mesma são a epiderme, derme e o tecido subcutâneo. Os cânceres de pele, em geral, se desenvolvem na região da epiderme. Imagem: http://www. wpclipart.com/medical

Através do cálculo das derivadas de segunda ordem do espectro de absorção de cada amostra, foi possível realizar a verificação da ocorrência de deslocamentos dos picos das bandas. Na figura 4.4 são apresentadas as derivadas referentes ao espectro médio de cada uma das linhagens celulares dos melanomas (figura 4.2(a)).

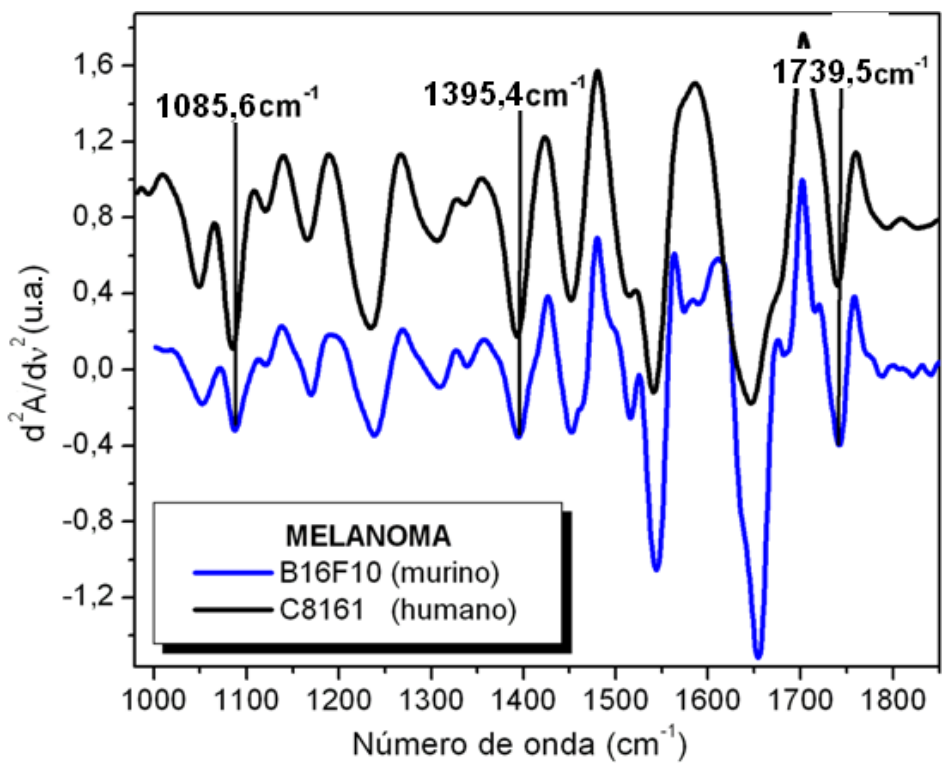

Figura 4.4: Derivadas de segunda ordem do espectro de absorção (figura 4.2(a) de ambas as linhagens de melanomas; são apresentados os valores do número de onda das bandas de absorção cujos deslocamentos dos picos, de uma linhagem com relação à outra, foram identificados. Os picos de absorção da linhagem C8161 foram adotados como referência.

A posição dos picos de cada banda com seu respectivo desvio padrão, assim como a associação química e biológica das mesmas, são apresentados na tabela 4.1. 


\begin{tabular}{|c|c|c|c|}
\hline \multicolumn{2}{|c|}{ Picos de Abs. $\left(\mathrm{cm}^{-1}\right)$} & \multicolumn{2}{|r|}{ Associação } \\
\hline C8161 & B16F10 & Química & Biológica \\
\hline $916,10(7)$ & $917,00(12)$ & $\nu \mathrm{CH}_{2}$ & Anel de ribose \\
\hline $968,30(13)$ & $966,40(5)$ & $\nu \mathrm{C}-\mathrm{C}$ e $\nu \mathrm{C}-\mathrm{O}$ & Esqueleto do DNA \\
\hline $1050,30(6)$ & $1049,80(7)$ & $\nu \mathrm{C}-\mathrm{O}$ & Carboidratos \\
\hline $1085,60(6)$ & $1087,70(6)$ & $\nu \mathrm{PO}_{2}$ sim & DNA (lig.fosfodiéster) \\
\hline $1122,00(6)$ & $1120,70(8)$ & $\nu \mathrm{C}-\mathrm{N}$ e $\nu \mathrm{C}-\mathrm{C}$ & RNA \\
\hline $1169,10(7)$ & $1169,40(5)$ & $\nu \mathrm{C}-\mathrm{O}$ & Serina, tirosina e carboidratos \\
\hline $1237,30(15)$ & $1238,10(7)$ & $\nu \mathrm{PO}_{2}$ assim. & DNA (lig.fosfodiéster) \\
\hline $1308,10(15)$ & $1308,20(11)$ & - & Amida III \\
\hline $1396,40(12)$ & $1393,60(5)$ & $\delta_{\varsigma} \mathrm{CH}_{3} \operatorname{sim}$ & Proteínas e lipídeos \\
\hline $1452,80(10)$ & $1452,60(11)$ & $\delta \varsigma \mathrm{CH}_{3}$ assim. & Proteínas e lipídeos \\
\hline $1543,00(11)$ & $1543,00(5)$ & $\delta \mathrm{N}-\mathrm{H}$ e $\nu \mathrm{C}-\mathrm{N}$ & Amida II \\
\hline $1643,00(17)$ & $1641,20(29)$ & $\nu \mathrm{C}=\mathrm{O}$ & Configuração $\beta$ - Amida I \\
\hline $1652,60(51)$ & $1653,20(38)$ & $\nu \mathrm{C}=\mathrm{O}$ & $\alpha$ hélice - Amida I \\
\hline $1739,50(7)$ & $1740,70(2)$ & $\nu \mathrm{C}=\mathrm{O}$ & Lipídeos (sebo) \\
\hline $2851,90(7)$ & $2851,30(4)$ & $\nu \mathrm{CH}_{2}$ sim. & Ácidos graxos \\
\hline $2922,70(7)$ & $2922,20(6)$ & $\nu \mathrm{CH}_{2}$ assim. & Ácidos graxos \\
\hline $2962,00(8)$ & $2960,80(3)$ & $\nu \mathrm{CH}_{3}$ assim. & Cadeias acila (lipídeos) \\
\hline $3062,10(16)$ & $3061,50(4)$ & $\nu \mathrm{CH}_{3}$ sim. & Cadeias acila (lipídeos) \\
\hline $3184,20(27)$ & $3186,50(2)$ & $\nu \mathrm{N}-\mathrm{H} \operatorname{sim}$ & Subestruturas "cis" ordenadas \\
\hline
\end{tabular}

Tabela 4.1: Principais bandas de absorção referentes às linhagens celulares de melanoma humano (C8161) e melanoma murino B16F10, cujas associações químicas e biológicas foram obtidas a partir de diversos trabalhos $[2,41,3,4,46,48,49]$. Os símbolos empregados na coluna referente à associação química estão relacionados aos modos vibracionais de estiramento $(\nu)$, modo vibracional de tesoura $(\varsigma)$, modo vibracional de flexão $(\delta)$, movimentos simétricos (sim.) e assimétricos (assim.).

Os deslocamentos foram analisados através do teste t de Student, considerando-se como intervalo de rejeição os valores de $p$ superiores a 0,05 ; alterações de posição foram observadas nas bandas situadas na região de $1086 \mathrm{~cm}^{-1}, 1395 \mathrm{~cm}^{-1}$ e $1740 \mathrm{~cm}^{-1}$, as quais 
estão destacadas na figura 4.4.

As bandas as quais apresentaram deslocamentos significativos correspondem aos modos vibracionais das moléculas de açúcar do DNA $\left(1085,60(6) \mathrm{cm}^{-1}\right)$, estiramento das moléculas de $\mathrm{C}=\mathrm{O}\left(1396,40(12) \mathrm{cm}^{-1}\right)$, presentes em proteínas e lipídeos, além do estiramento do $\mathrm{CH}_{2}$ e $\mathrm{CH}_{3}$ dos lipídeos $\left(1739,50(7) \mathrm{cm}^{-1}\right)$; os picos de absorção citados são referentes à linhagem C8161 como referência.

Embora o foco principal deste trabalho seja a caracterização bioquímica das diversas linhagens celulares, identificando as alterações moleculares através da análise dos deslocamentos dos picos das bandas de absorção e análise das áreas das mesmas, algumas suposições com relação à natureza biológica das diferenças espectrais verificadas serão apresentadas.

Uma primeira suposição está relacionada ao deslocamento do pico de absorção relacionado os estiramento açúcar do DNA $\left(1085,60(6) \mathrm{cm}^{-1}\right)$; para apresentar a hipótese associada a este fato, será necessária a explicação de alguns pontos, conforme apresentados a seguir.

Os telômeros - ou porção final do cromossomo - são um complexo nucleoprotéico composto de DNA de fita simples e dupla, permeados por proteínas [57]; os telômeros constituem uma seqüência chave a qual indica o início e término da informação genética durante a replicação do DNA, sendo na maioria dos eucariontes composto por uma seqüência rica em guanina $(G)$ e citosina $(C)$, conforme pode ser observado na figura 4.5 .

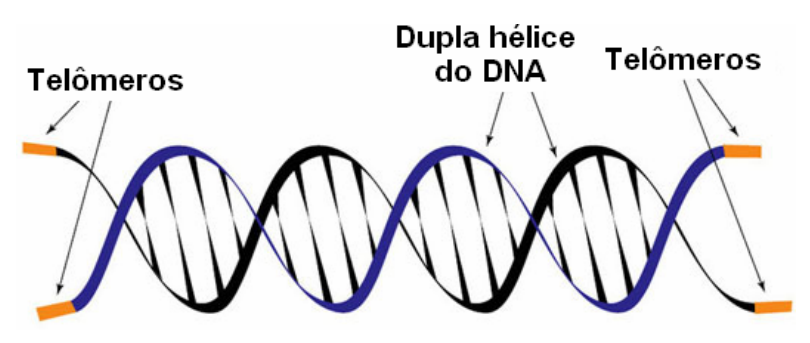

Figura 4.5: Esquema de um cromossomo, em cujas extremidades localizam-se os telômeros. Estes constituem uma seqüência chave a qual indica o início e término da informação genética durante a replicação do DNA, sendo uma seqüência de guanina (G) e citosina (C). Imagem: adaptada de http://www.biochem.med.umich.edu

Uma das maiores diferenças entre células humanas e murinas está relacionada ao tamanho dos telômeros das mesmas $[57,58,59]$. Células humanas possuem cerca de 10000 pares de base, enquanto que as células murinas possuem cerca de 40000 - 60000 pares de base.

Uma vez que as células murinas possuem telômeros cerca de 4 a 6 vezes mais extensos do que as células humanas, os cromossomos das células murinas são mais extensos. Com isto, supomos que a diferença de tamanho dos cromossomos (compostos pela seqüência 
de DNA e telômeros, conforme mostrado na figura 4.5) pode ser um dos fatores associados ao deslocamento dos picos das bandas de absorção apresentado pelas bandas localizadas na região referente ao DNA. Uma vez que o enovelamento da molécula de DNA está diretamente relacionado à sua dimensão, a quantidade de histonas necessárias para que o enovelamento da molécula seja realizado de maneira satisfatória, aumenta.

As histonas são um tipo de proteína, compostas basicamente por dois tipos de aminoácidos: a lisina e a arginina. As histonas, que possuem carga positiva devido à alta proporção de aminoácidos, formam um complexo com os grupos fosfatados do DNA, os quais são carregados negativamente. Na figura 4.6 é apresentado um esquema através do qual podemos observar onde a histona se situa no processo de enovelamento do DNA; a unidade básica da cromatina é o nucleossomo, que por sua vez consiste em, aproximadamente, 146 pares de bases do DNA enroladas ao redor das histonas [57, 34].

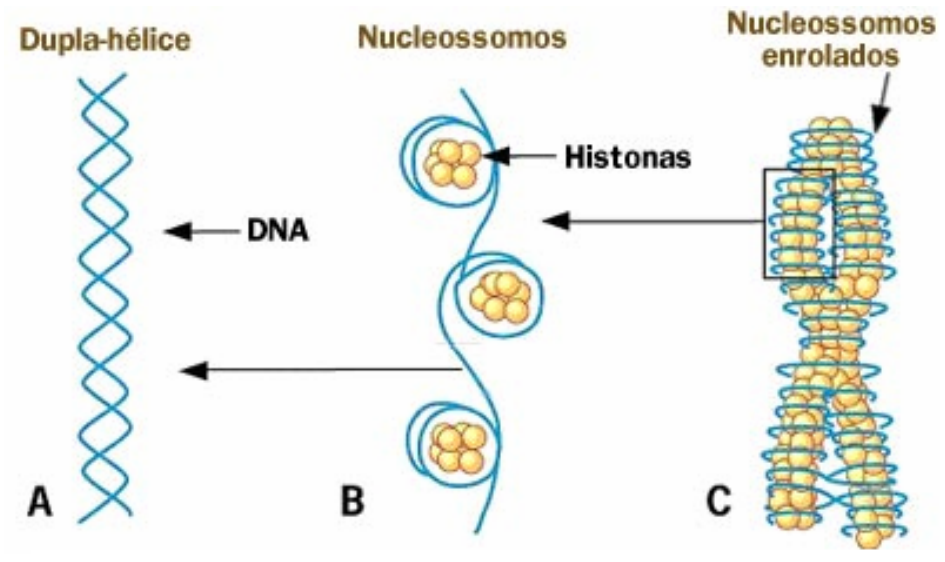

Figura 4.6: Esquema ilustrativo da compactação do DNA: a dupla hélice (A) é enrolada em histonas (B); estes são denominados nucleossomos, os quais são agrupados formando uma fibra através da qual é formada a cromatina e, conseqüentemente os cromossomos (C). Imagem: adaptada de http://www.biochem.med.umich.edu

Desta forma, sendo o tamanho da molécula de DNA de ambas as células distinto, há uma maior concentração de histonas numa linhagem celular do que em outra; desta forma, supomos que tal fato possa contribuir com o deslocamento do pico de absorção relativo ao DNA, tendo em vista que as bandas de absorção são afetadas pelo acréscimo ou decréscimo de ligações químicas (entre as histonas e a molécula de DNA) necessárias para que o processo de enovelamento seja realizado com sucesso.

Considerando-se duas linhagens celulares referentes a um mesmo grupo (melanoma), é natural esperarmos semelhanças com relação à composição básica das mesmas, porém é desejável também identificar bandas de absorção com características distintas através das quais seja possível obter diferenças bioquímicas entre as amostras estudadas.

Cada banda de absorção foi analisada individualmente, através do cálculo das áreas das mesmas, conforme descrito na seção 3.3. Na tabela 4.2 são apresentados os valores 
médios das áreas das bandas de absorção de cada uma das linhagens. Através do teste t de Student, foram consideradas portadoras de diferenças espectrais significativas, as bandas de absorção as quais apresentaram um valor de $p$ (intervalo de rejeição) inferior à 0,05 .

\begin{tabular}{|c|c|c|c|}
\hline Picos de Abs. $\left(\mathrm{cm}^{-1}\right)$ & C8161 & B16F10 & $\mathbf{p}$ \\
\hline $916,10(7)$ & $0,04(1)$ & $0,03(2)$ & 0,340 \\
\hline $968,30(13)$ & $0,14(2)$ & $0,10(3)$ & 0,550 \\
\hline $1050,30(6)$ & $0,04(1)$ & $0,04(1)$ & 0,786 \\
\hline $1085,60(6)$ & $2,62(21)$ & $2,39(8)$ & 0,357 \\
\hline $1122,00(6)$ & $0,03(1)$ & $0,03(1)$ & 0,087 \\
\hline $1169,10(7)$ & $0,03(1)$ & $0,04(1)$ & 0,039 \\
\hline $1237,30(15)$ & 1,00 & 1,00 & - \\
\hline $1308,10(15)$ & $0,05(1)$ & $0,07(1)$ & 0,005 \\
\hline $1396,40(12)$ & $0,53(2)$ & $0,52(4)$ & 0,730 \\
\hline $1452,80(10)$ & $0,29(3)$ & $0,36(4)$ & 0,140 \\
\hline $1543,00(11)$ & $2,22(18)$ & $2,77(22)$ & 0,020 \\
\hline $1646,90(15)$ & $5,11(89)$ & $5,57(20)$ & 0,009 \\
\hline $1652,60(33)$ & $1,25(22)$ & $2,77(14)$ & 0,003 \\
\hline $1739,50(7)$ & $0,08(1)$ & $0,12(6)$ & 0,130 \\
\hline $2851,90(7)$ & $0,10(2)$ & $0,16(2)$ & 0,027 \\
\hline $2922,70(7)$ & $0,26(3)$ & $0,46(1)$ & 0,001 \\
\hline $2962,00(8)$ & $0,20(9)$ & $0,10(6)$ & 0,510 \\
\hline $3062,10(16)$ & $0,07(1)$ & $0,10(3)$ & 0,001 \\
\hline $3184,20(27)$ & $0,05(1)$ & $0,06(2)$ & 0,026 \\
\hline
\end{tabular}

Tabela 4.2: Valor médio da área das bandas de absorção, onde C8161 corresponde a linhagem de melanoma humano e B16F10 corresponde a linhagem de melanoma murino. As bandas as quais apresentam um valor de $p$ menor que 0,05 (através do teste t de Student), foram consideradas distintas. A posição do pico de absorção é exibida considerando-se a linhagem C8161 como referência.

Na primeira coluna da tabela 4.2 é apresentada a posição aproximada da banda de 
absorção analisada, considerando-se a posição média do pico de absorção da linhagem C8161 (melanoma humano) como referência. O valor médio da área da banda de cada linhagem, e sua respectiva incerteza, são apresentados na segunda e terceira colunas, respectivamente. Finalmente, na última coluna, são mostrados os valores de $p$ obtidos através do teste $t$ de Student.

A banda de absorção localizada em 1237,30(15) $\mathrm{cm}^{-1}$, associada ao estiramento das moléculas de $\mathrm{PO}_{2}$, foi utilizada como referência para a normalização do espectro, visando eliminar efeitos relacionados à diferença no número de células existentes em cada filme depositado nas janelas de $\mathrm{CaF}_{2}$, conforme explicado na seção 3.3 .

Observando-se a tabela 4.2 é possível notar que diversas bandas de absorção referentes às proteínas apresentam valores das áreas distintos, de acordo com o intervalo de confiança adotado. As bandas das células de melanoma murino, situadas em $1169,40(5) \mathrm{cm}^{-1}, 1308,10(15) \mathrm{cm}^{-1}, 1543,00(11) \mathrm{cm}^{-1}$ e $1646,90(15) \mathrm{cm}^{-1}$ relativas à serina e tirosina, amida III, amida II e amida I, respectivamente, apresentam um maior valor de área com relação às células de melanoma humano.

A maior parte dos cânceres epiteliais humanos são caracterizados por um cariótipo anormal, contendo diversas translocações, as quais não são comumente observadas em camundongos [59].

As células humanas possuem uma alta estabilidade, uma vez que tumores em humanos são originados basicamente a partir de distúrbios em duas vias sinalizadoras: uma via envolvendo o gene p53 e outra ligada à via Ras-Raf-MAPK. Os tumores murinos são ocasionados por distúrbios em cerca de seis ou mais vias sinalizadoras: p53, RB, PP2A, Ral-GEF, etc [59].

A sinalização celular (ou via sinalizadora) faz parte de um complexo sistema de processos químicos celulares básicos, os quais regem as atividades e ações das células. Tais vias estão relacionadas a processos através dos quais as células são capazes de responder corretamente ao seu "micro ambiente", regendo o desenvolvimento celular, reparação tecidual, imunidade, além da manutenção da homeostase tecidual. Os erros no processamento da informação celular são responsáveis por doenças como o câncer [37]. Muitos são os sinais celulares transportados por moléculas denominadas receptores, as quais desencadeiam uma série de reações químicas. Tais sinais são transportados, por exemplo, através de uma classe de proteínas receptoras.

O p53 é um gene supressor de tumor, o qual atua como um regulador da transcrição induzida por dano ao DNA. O gene p53 sintetiza uma proteína de mesmo nome, que possui importância fundamental na regulação do ciclo celular e apoptose. Quando esta proteína sofre mutação, há uma associação a diversos graus de comportamento neoplásico, uma vez que o produto de vários genes (com função de estacionar o ciclo celular), pode ser alterado por esta proteína, desregulando a apoptose das células que sofreram dano em seu DNA. 
Outra via explorada por células cancerosas é a troca qualitativa de receptores, substituindo, por exemplo, a produção dos receptores de integrinas que inibem a proliferação, pela produção de receptores de integrinas promotoras de proliferação. As integrinas são uma família de receptores de superfície que estão envolvidos na angiogênese, na qual as inibidoras têm efeitos diretos na prevenção do crescimento, angiogênese e metástase tumorais. Em todos os casos acima, ocorre a ativação dos caminhos intracelulares de indução mitótica, envolvendo com freqüência a via sinalizadora Ras-Raf-MAPK.

A Ras-Raf-MAPK é uma via sinalizadora que relaciona respostas dos receptores da superfície celular aos fatores de crescimento da mesma. Esta via é muito complexa cujos principais componentes são apresentados na figura 4.7; em muitos tipos de células, a ativação desta via sinalizadora promove a divisão celular.

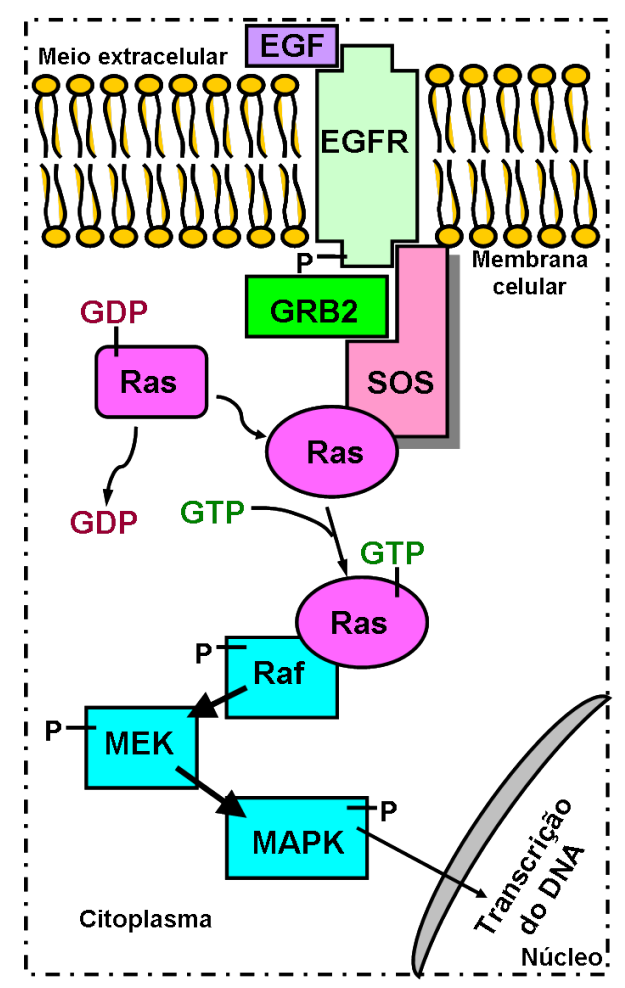

Figura 4.7: Esquema ilustrando a cascata metabólica da via sinalizadora Ras-RafMAPK: o fator de crescimento epidérmico (EGF) ativa o receptor do fator de crescimento epidérmico (EGFR), que por sua vez estimula a atividade de receptores catalíticos, ativando diversas proteínas, entre elas a proteína Ras. Esta está relacionada com o receptor catalítico tirosina-quinase e é codificada pelo gene Raf. A Ras é ativada quando combinada com GTP, podendo se ligar a outras proteínas que estimulam a via sinalizadora MAPK, dirigindo a proliferação e diferenciação celular. Imagem: adaptada de http://www. cellsignal.com

O fator de crescimento epidérmico, ou EGF, é um fator de crescimento que desempenha um papel importante na regulação do crescimento celular, proliferação e diferenciação; esta proteína ativa o receptor do fator de crescimento epidérmico (EGFR), que 
por sua vez estimula a atividade de receptores catalíticos, tais como a tirosina-quinase, GRB2, etc. A ação destes receptores, ativa diversas proteínas, entre elas a proteína Ras.

A proteína Ras encontra-se diretamente relacionada com o receptor catalítico tirosinaquinase em sua porção intracelular, uma vez que a proteína Ras encontra-se ligada à superfície citoplasmática da membrana celular. Raf é um gene que codifica para uma proteína quinase (neste caso, a Ras).

A proteína Ras participa da transmissão, até o interior do núcleo celular, da informação recebida por um receptor, para estimular a diferenciação e a multiplicação da célula.

A proteína Ras está ativada quando combinada com GTP (guanosina-tri-fosfato, molécula semelhante ao ATP e é utilizada para armazenar e fornecer energia celular) e inativa quando ligada a GDP (guanosina-di-fosfato). Ativa, a Ras pode se ligar a outras proteínas que estimulam a via sinalizadora MAP-quinase, ou MAPK, e dirigir a proliferação e diferenciação celular.

Alterações nestes caminhos ou cascatas metabólicas constituem dos mecanismos mais complexos utilizadas por células tumorais. Em suma, este estímulo é gerado no meio extracelular, transmitido através da membrana celular e destinado ao núcleo da célula, onde alterações na expressão gênica modificam o comportamento celular de alguma forma. Porém, alguns destes sinais não precisam penetrar no núcleo celular para causar o efeito desejado pois, muitas vezes, é suficiente provocar alterações estruturais em proteínas já presentes no citosol para desencadear alterações celulares.

Desta forma, podemos supor que a produção de proteínas e outras biomoléculas são diretamente afetadas por estas vias sinalizadoras. Uma vez que mais vias estão relacionadas ao desenvolvimento tumoral murino, pode-se esperar que as áreas das bandas de absorção referentes às proteínas seja maior em camundongos do que em células humanas, as quais possuem apenas duas vias sinalizadoras afetadas.

Observando-se as áreas referentes às bandas de absorção localizadas na região entre $2850-2930 \mathrm{~cm}^{-1}$, possivelmente correspondentes aos lipídeos das membranas celulares, podemos notar que as células de melanoma murino possuem uma maior quantidade de ligações químicas do que as células de melanoma humano.

As diferenças observadas com relação à região referente aos lipídeos de ambas as linhagens, podem ser associadas à fluidez da membrana celular. Alguns processos de transporte através da membrana e atividades enzimáticas, por exemplo, cessam quando a viscosidade dos lipídeos é experimentalmente elevada a um nível limítrofe [60].

A fluidez da membrana está relacionada com a composição e temperatura corpórea [58]. Em geral, camundongos possuem uma temperatura corpórea média de cerca de $36^{\circ} \mathrm{C}[58,59]$, enquanto que a temperatura corporal humana é de cerca de $37^{\circ} \mathrm{C}$.

A fisiologia e a morfologia das células murinas e humanas são semelhantes no sentido de que ambas necessitam de uma certa fluidez para que os processos biológicos sejam 
mantidos de maneira adequada; porém para que a fluidez da membrana seja mantida estável à medida que a temperatura corporal decresce, ácidos graxos são sintetizados com mais ligações do tipo dupla "cis" [59].

Uma ligação do tipo "cis" quer dizer que os átomos de carbonos adjacentes estão do mesmo lado da dupla ligação. A estabilidade da dupla ligação torna o ácido graxo menos flexível. Quanto maior for o número de duplas ligações, maior é a estabilidade da molécula de ácido graxo.

Desta forma, pode-se supor que estas ligações "extras" são necessárias para a manutenção da fluidez da membrana celular murina, acarretando por sua vez, no aumento da área da banda de absorção referente aos lipídeos.

Por fim, as duas linhagens são semelhantes com relação às bandas de absorção relacionadas às moléculas de DNA, as quais estão localizadas em 916,10(7) $\mathrm{cm}^{-1}$ (anéis de ribose) $[2,3,4]$ e 968,30(13) $\mathrm{cm}^{-1}$ (ligações $\mathrm{C}-\mathrm{C}$ e $\mathrm{C}-\mathrm{O}$ do esqueleto do DNA) $[2,3,4]$. Algumas bandas associadas à ligações provenientes de proteínas não apresentaram diferenças significativas.

Através da identificação das bandas de absorção, pelo cálculo das áreas e verificação de deslocamento dos picos, foi possível diferenciar ambas as linhagens celulares deste grupo, além de atingir o objetivo de obter uma associação bioquímica para as bandas de absorção estudadas, demonstrando a viabilidade da utilização da espectroscopia por FTIR no estudo de amostras biológicas.

\subsection{Adenocarcinoma de Cérvix vs. Adenocarcinoma de Cólon}

De acordo com estatísticas disponíveis [52], o câncer de cérvix é o segundo tipo de câncer responsável pela maior mortalidade feminina. Cânceres de cérvix são curáveis quando detectados precocemente; programas de prevenção têm reduzido significativamente a incidência e mortalidade relacionada ao câncer de cérvix em países industrializados $[52$, 37 .

O desenvolvimento do câncer de cérvix é gradual e pode levar anos. Inicialmente, há pequenas alterações nas células superficiais do colo uterino, o qual é apresentado na figura 4.8. Conforme as alterações se tornam mais anormais, elas causam a displasia, condição pré-maligna do colo do útero. A displasia pode progredir e transformar-se em câncer pré-invasivo que ocupa apenas a camada externa do colo do útero. Eventualmente, o câncer se propaga para as camadas mais profundas e, finalmente, se não for tratado, para outros órgãos pélvicos. 


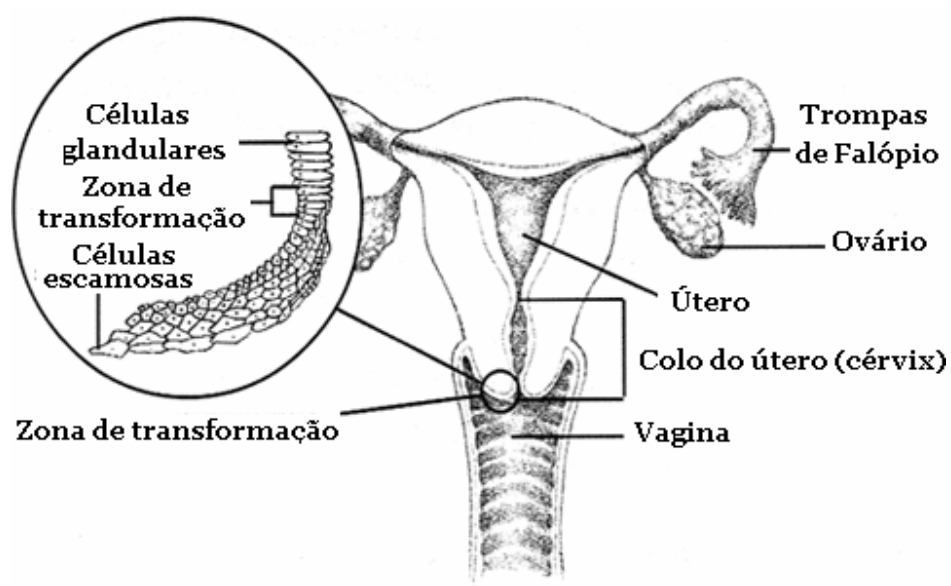

Figura 4.8: Ilustração dos órgãos reprodutores femininos; vale destacar a localização do cérvix (ou colo do útero), região a qual é composta basicamente por células epiteliais glandulares e escamosas. Imagem: http://www.wpclipart.com/medical

Analogamente a outros tumores sólidos de adultos, o câncer de cérvix possui um desenvolvimento e progresso largamente relacionado com a ativação e mutação de oncogenes combinada com a inativação de genes supressores de tumores [61].

Alterações de tais genes possuem importantes efeitos relacionados ao controle do crescimento celular e diferenciação; porém, de acordo com a literatura [38, 61], tais efeitos parecem não desempenhar um papel importante na tumorigênese cervical.

O câncer de cérvix difere das demais doenças malignas umas vez que este é fortemente associado à agentes infecciosos, o "papilomavírus humano" (HPV). Esta forte associação tem sido utilizada como grande vantagem nas pesquisas de laboratório, uma vez que os HPVs fornecem uma poderosa ferramenta através da qual os mecanismos moleculares do desenvolvimento dos tumores de cérvix e progressão dos mesmos podem ser examinadas $[61,38]$

Já os tumores de cólon progridem através de uma série de estágios clínicos e histopatológicos, variando de uma lesão de cripta simples, de pequenos tumores benignos (denominados pólipos adenomatosos) até atingir o nível de cânceres malignos (carcinomas); um esquema ilustrativo da evolução da doença, de acordo com os estágios do avanço da mesma é mostrado na figura 4.9.

Esta progressão é o resultado de uma série de alterações genéticas as quais envolvem desde a ativação de oncogenes até a inativação de genes supressores de tumores, analoga- 
mente ao caso dos cânceres de cérvix.

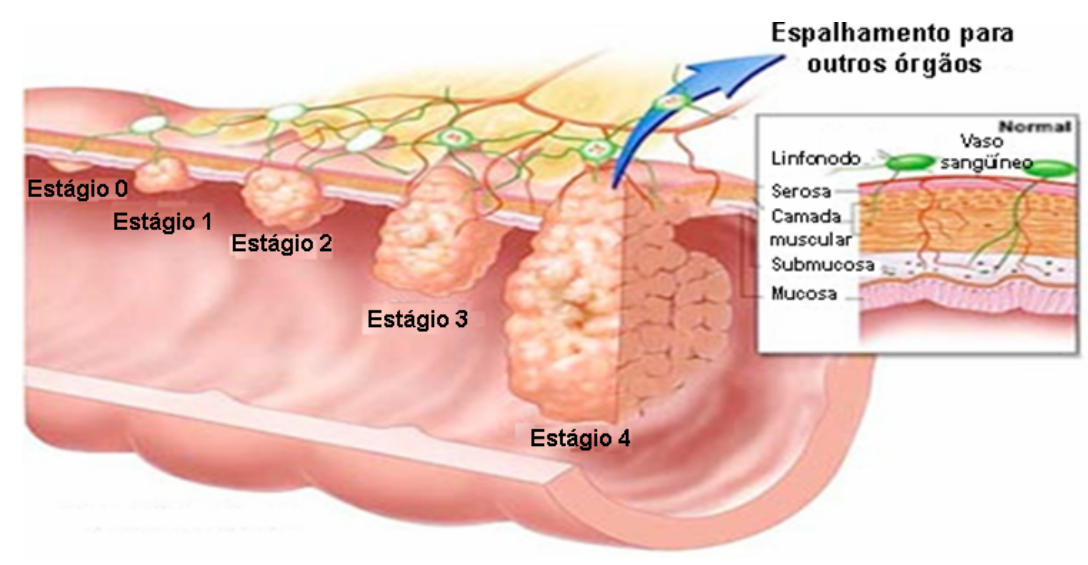

Figura 4.9: Progressão dos tumores de cólon: os estágios 0 e 1 correspondem à lesão de cripta simples; os estágios 2 e 3, são caracterizados por pequenos tumores benignos (denominados pólipos adenomatosos); estes tumores, caso não sejam tratados, crescem até atingir o nível de cânceres malignos (estágio 4 - carcinomas). Imagem: http:// cancer.med.upenn.edu

Nesta etapa do estudo, foi realizada a análise dos espectros da linhagem celular HT-29, correspondente ao adenocarcinoma de cólon, e da linhagem HeLa, referente ao adenocarcinoma de cérvix.

Um espectro médio referente a cada uma das linhagens celulares foi apresentado anteriormente, na figura 4.2. Primeiramente, foram identificadas as bandas de absorção e determinados eventuais deslocamentos dos picos das mesmas através do teste $\mathrm{t}$ de Student, considerando-se como intervalo de rejeição os valores de $p$ superiores a 0,05 .

Os deslocamentos dos picos de absorção foram determinados através da análise da derivada de segunda ordem dos espectros de absorção de cada linhagem, conforme apresentados na figura 4.10 .

Foi possível identificar deslocamentos significativos (considerando o teste t de Student, com $p<0,05)$ nos picos situados nas regiões de 1084, 80(3) $\mathrm{cm}^{-1}, 1158,70(10) \mathrm{cm}^{-1}$, $1453,90(5) \mathrm{cm}^{-1}$ e 3060, 90(5) $\mathrm{cm}^{-1}$; os picos de absorção citados são referentes à linhagem HeLa como referência. 


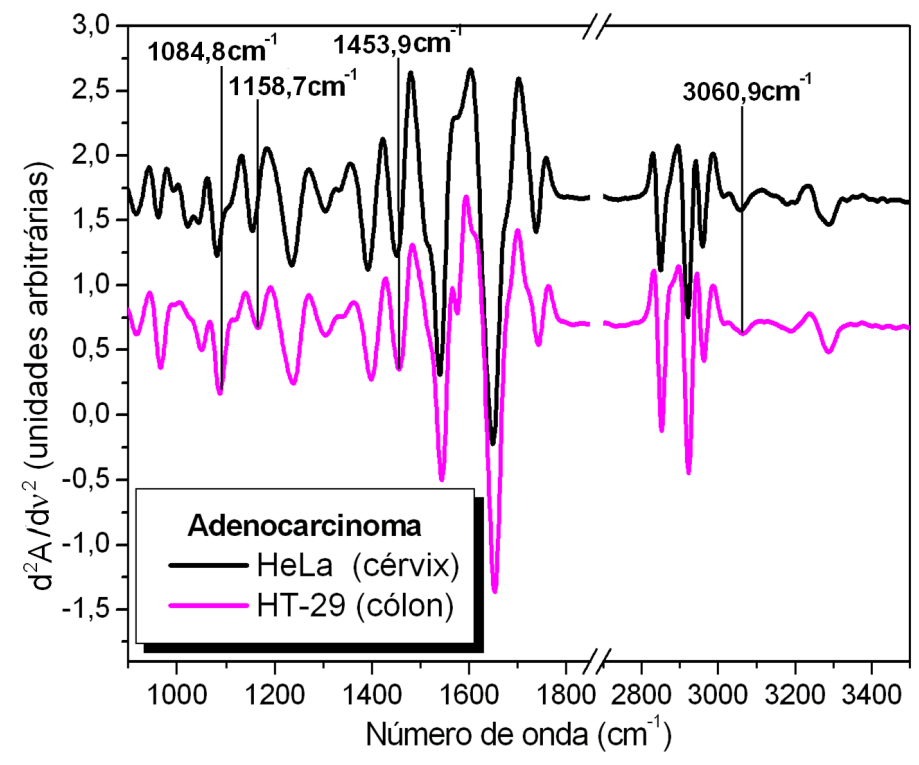

Figura 4.10: Derivadas de segunda ordem do espectro de absorção das linhagens de adenocarcinomas de cérvix (HeLa) e de cólon (HT-29); são apresentados os valores do número de onda das bandas de absorção cujos deslocamentos dos picos, de uma linhagem com relação à outra, foram identificados. Os picos de absorção da linhagem HeLa foram adotados como referência.

O valor médio da posição referente a cada banda de absorção assim como suas respectivas incertezas, são apresentadas na tabela 4.3. Nas colunas situadas à direita, são apresentadas as associações químicas e biológicas referentes a cada banda de absorção. Tanto para a linhagem de adenocarcinoma de cérvix (HeLa) quanto para a de adenocarcinoma de cólon (HT-29), foram efetuados testes estatísticos para a verificação dos deslocamentos dos picos de uma linhagem com relação à outra.

\begin{tabular}{|c|c|c|c|}
\hline \multicolumn{2}{|c|}{ Picos de Abs. $\left(\mathrm{cm}^{-1}\right)$} & \multicolumn{2}{|c|}{ Associação } \\
\hline HeLa & HT-29 & Química & Biológica \\
\hline \hline $918,10(6)$ & $919,60(8)$ & $\nu \mathrm{CH}_{2}$ & Anel de ribose \\
\hline $967,20(8)$ & $966,40(2)$ & $\nu \mathrm{C}-\mathrm{C}$ e $\nu \mathrm{C}-\mathrm{O}$ & Esqueleto do DNA \\
\hline $1049,90(6)$ & $1049,40(7)$ & $\nu \mathrm{C}-\mathrm{O}$ & Carboidratos \\
\hline $1084,80(3)$ & $1085,70(3)$ & $\nu \mathrm{PO}_{2}$ sim. & DNA \\
\hline $1121,40(3)$ & $1120,80(5)$ & $\nu \mathrm{C}-\mathrm{N} \mathrm{e} ~_{\mathrm{C}} \mathrm{C}-\mathrm{C}$ & RNA \\
\hline $1158,70(10)$ & $1166,20(4)$ & $\nu \mathrm{C}-\mathrm{O}$ & Serina,tirosina e carboidratos \\
\hline $1238,50(7)$ & $1237,70(7)$ & $\nu \mathrm{PO}_{2}$ assim. & DNA \\
\hline
\end{tabular}

(continua na próxima página) 


\begin{tabular}{|c|c|c|c|}
\hline \multicolumn{2}{|c|}{ Picos de Abs. $\left(\mathrm{cm}^{-1}\right)$} & \multicolumn{2}{|c|}{ Associação } \\
\hline HeLa & HT-29 & Química & Biológica \\
\hline \hline $1308,50(3)$ & $1307,30(8)$ & - & Amida III \\
\hline $1396,70(8)$ & $1396,10(8)$ & $\delta \varsigma \mathrm{CH}_{3}$ sim. & Proteínas e lipídeos \\
\hline $1453,90(5)$ & $1456,30(8)$ & $\delta \varsigma \mathrm{CH}_{3}$ assim. & Proteínas e lipídeos \\
\hline $1545,20(12)$ & $1543,20(4)$ & $\delta \mathrm{N}-\mathrm{H}$ e $\nu \mathrm{C}-\mathrm{N}$ & Amida II \\
\hline $1646,20(11)$ & $1641,80(90)$ & $\nu \mathrm{C}=\mathrm{O}$ & Configuração $\beta$ - Amida I \\
\hline $1650,70(19)$ & $1653,10(60)$ & $\nu \mathrm{C}=\mathrm{O}$ & $\alpha$ hélice - Amida I \\
\hline $1742,30(4)$ & $1742,70(6)$ & $\nu \mathrm{C}=\mathrm{O}$ & Lipídeos (sebo) \\
\hline $2852,00(2)$ & $2851,60(4)$ & $\nu \mathrm{CH}_{2}$ sim. & Ácidos graxos \\
\hline $2922,90(4)$ & $2922,00(6)$ & $\nu \mathrm{CH}_{2}$ assim. & Ácidos graxos \\
\hline $2961,70(2)$ & $2961,70(6)$ & $\nu \mathrm{CH}_{3}$ assim. & Cadeias acila (lipídeos) \\
\hline $3060,90(5)$ & $3063,80(7)$ & $\nu \mathrm{CH}_{3}$ sim. & Cadeias acila (lipídeos) \\
\hline $3187,40(2)$ & $3183,50(15)$ & $\nu \mathrm{C}=\mathrm{C}-\mathrm{H}$ sim.$^{-}$ \\
\hline
\end{tabular}

Tabela 4.3: Principais bandas de absorção referentes às linhagens celulares de adenocarcinoma de cérvix (HeLa) e adenocarcinoma de cólon HT-29, cujas associações químicas e biológicas foram obtidas a partir de diversos trabalhos $[2,41,3,4,46,48,49]$. Os símbolos empregados na coluna referente à associação química estão relacionados aos modos vibracionais de estiramento $(\nu)$, modo vibracional de tesoura $(\varsigma)$, modo vibracional de flexão $(\delta)$, movimentos simétricos (sim.) e assimétricos (assim.).

Observando-se os valores exibidos na tabela 4.3, pode-se notar alguns deslocamentos de picos significativos, os quais foram destacados na figura 4.10. Estas bandas de absorção correspondem ao estiramento simétrico das ligações das moléculas de $\mathrm{PO}_{2}$ (1084, 80(3) $\left.\mathrm{cm}^{-1}\right)$, estiramento simétrico das ligações $\mathrm{C}-\mathrm{O}$ da serina, tirosina e carboidratos $\left(1158,70(10) \mathrm{cm}^{-1}\right)$, vibrações do tipo "tesoura" e flexão assimétrica referentes às moléculas de $\mathrm{CH}_{3}$ e estiramento simétrico das moléculas de $\mathrm{CH}_{3}$, contidas nas cadeias acila dos lipídeos $\left(3060,90(5) \mathrm{cm}^{-1}\right)$.

O deslocamento do pico de absorção observado na região próxima à $1085 \mathrm{~cm}^{-1}$ está relacionado a uma forte interação intramolecular dos ácidos nucléicos [62, 63], interação que por sua vez, é influenciada pelo tamanho da molécula de DNA em questão; este deslocamento pode estar associado à presença de DNA viral (HPV) na linhagem celular HeLa, uma vez que esta é relacionada ao HPV-18 [64, 38].

Em cerca de $90 \%$ dos carcinomas cervicais invasivos têm sido encontradas seqüências 
de DNA pertencentes a um tipo particular de HPV [64, 65]. Os papilomavírus são um tipo de "DNA-vírus" formado por aproximadamente 8000 pares de bases, contidos numa cápsula viral de aproximadamente $55 \mathrm{~nm}$.

Os papilomavírus possuem uma certa preferência pelo epitélio escamoso da pele e das mucosas. Em humanos, por exemplo, os HPVs dos tipos 1, 2 e 4 causam geralmente verrugas comuns nas mãos e nos pés [37]. Os HPVs 6 e 11 causam verrugas genitais e os HPVs 16 e 18 são encontrados em neoplasias intra-epiteliais cervicais e em carcinomas escamosos de colo do útero e de pênis [37].

O ciclo biológico dos HPVs, conforme apresentado na figura 4.11, tem início quando os vírus penetram nas células da camada mais profunda da pele ou das mucosas, as quais possuem células menos diferenciadas do epitélio [66].

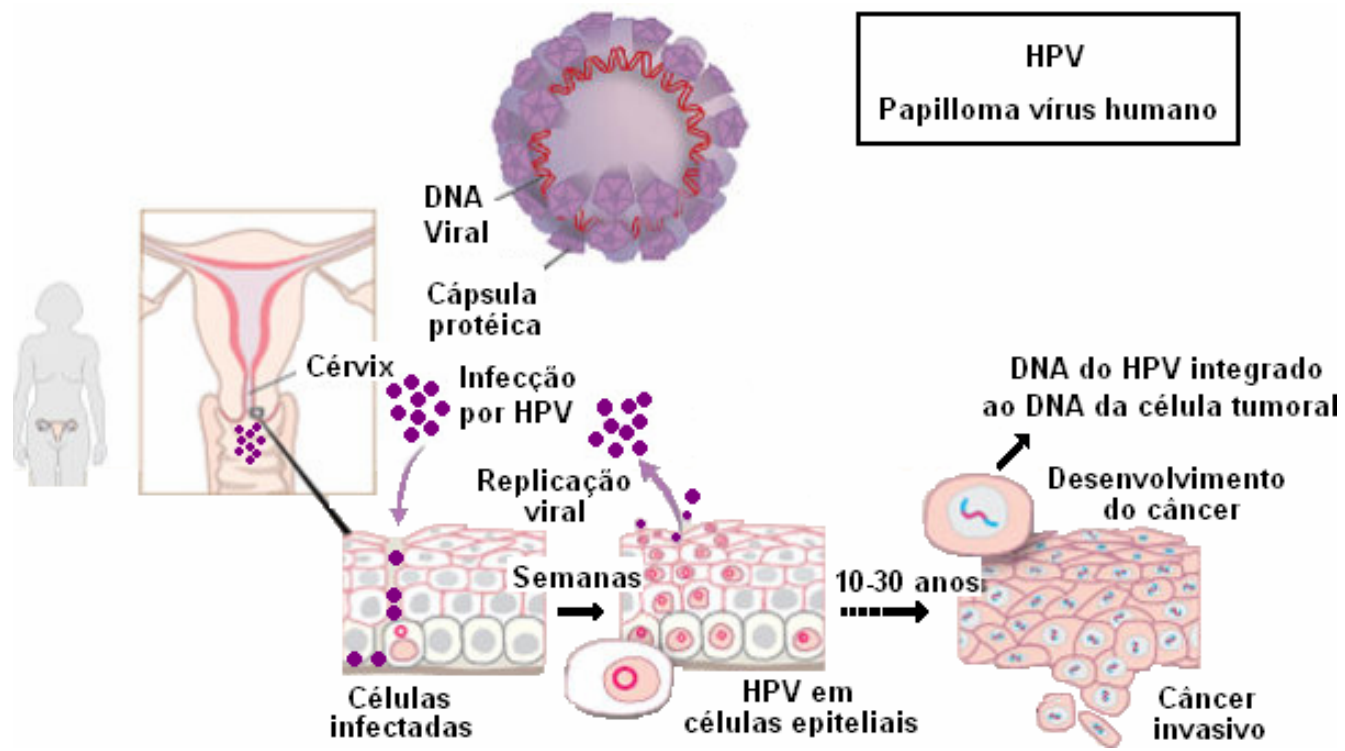

Figura 4.11: Ciclo biológico dos HPVs: partículas virais penetram nas células da camada mais profunda, a qual é composta pelas células menos diferenciadas do epitélio escamoso. O vírus penetra na célula através da interação das proteínas do capsídeo com receptores específicos da superfície celular. Após penetrar na célula, o vírus expõe seu DNA a ação de enzimas nucleares, as quais favorecem a expressão dos genes virais. Imagem adaptada de http://www.thebody.com

Fissuras nesse epitélio possibilitam o acesso do vírus a essas células. O virion viral (cápsula protéica e DNA viral) penetra na célula através da interação das proteínas do capsídeo com receptores específicos da superfície celular. Após penetrar na célula, o virion perde seu capsídeo, expondo seu DNA à ação de enzimas nucleares, as quais favorecem a expressão dos genes virais [66].

Nos estágios precoces da infecção, o DNA se replica, concomitantemente ao DNA celular, gerando de vinte a cinqüenta cópias virais por célula. Nos HPV associados a cânceres cervicais é observada, com freqüência, a integração do DNA do vírus a um 
cromossomo do hospedeiro $[67,68]$.

A proteína E2 desempenha um papel central no ciclo de vida viral, a expressão da proteína E2 apresenta como conseqüência, a diminuição da expressão das proteínas E6 e E7, as quais agem como supressoras tumorais, controlando a proliferação da célula [66, 69]. Quando ocorre a integração do genoma viral ao DNA celular e a inibição do gene E2, os genes que codificam as proteínas E6 e E7 perdem a função inibitória e passam a ser expressos em maior quantidade, aumentando a concentração das proteínas E6 e E7 no citoplasma e no núcleo da célula infectada [69]. Dessa forma, apesar da proteína E2 não apresentar atividade transformante, seu mecanismo de ação é relevante para a indução do processo de imortalização celular promovido pelos HPVs de alto risco [70].

Sendo a linhagem HeLa (adenocarcinoma de cérvix) derivada do HPV-18 (carcinoma cervical positivo) [64, 38], embora diversas outras alterações estejam ocorrendo, supomos que o deslocamento do pico de absorção situado em cerca de $1085 \mathrm{~cm}^{-1}$ esteja parcialmente relacionado à presença do DNA viral, o qual está incorporado às células HeLa. Desta forma, supomos que esta porção de DNA presente na linhagem celular linhagem HeLa, porém ausente na linhagem HT-29 (adenocarcinoma de cólon), é responsável pelo deslocamento do pico de absorção observado.

Podemos supor ainda que, as alterações observadas na bandas de absorção situadas em cerca de $1158 \mathrm{~cm}^{-1}$ e $1453 \mathrm{~cm}^{-1}$, relacionadas às ligações covalentes $\mathrm{C}-\mathrm{O}$ presentes nos aminoácidos (serina e tirosina), proteínas e lipídeos, estejam relacionadas também à expressão das proteínas envolvidas no ciclo de infecção celular pelo HPV (E2, E6 e E7), embora muitas outras proteínas também apresentem alterações ao longo do ciclo celular.

Após a identificação das bandas de absorção presentes em cada amostra, foram calculas as áreas das mesmas, visando a comparação relativa dos componentes celulares de uma linhagem com relação à outra. Por se tratarem de linhagens provenientes do tecido epitelial, foram identificadas algumas bandas de absorção cujas áreas são semelhantes, de acordo com a análise estatística feita com o teste t de Student (considerando $p>0,05$ como sendo o intervalo de rejeição). Os valores médios obtidos para cada uma das duas linhagens, assim como as respectivas incertezas são apresentados na tabela 4.4.

A posição média das bandas, mostrada na primeira coluna, é apresentada considerandose a linhagem celular HeLa (adenocarcinoma de cérvix) como referência.

\begin{tabular}{|c|c|c|c|}
\hline Picos de Abs. $\left(\mathrm{cm}^{-1}\right)$ & HeLa & HT-29 & p \\
\hline \hline $918,10(6)$ & $0,06(1)$ & $0,04(1)$ & 0,0460 \\
\hline $967,20(8)$ & $0,14(2)$ & $0,07(1)$ & 0,0110 \\
\hline $1049,90(6)$ & $0,05(1)$ & $0,07(2)$ & 0,2900 \\
\hline
\end{tabular}

(continua na próxima página) 


\begin{tabular}{|c|l|l|c|}
\hline Picos de Abs. $\left(\mathrm{cm}^{-1}\right)$ & HeLa & HT-29 & p \\
\hline \hline $1084,80(3)$ & $0,48(2)$ & $0,02(1)$ & 0,0001 \\
\hline $1121,40(3)$ & $0,02(1)$ & $0,04(1)$ & 0,2800 \\
\hline $1158,70(10)$ & $0,07(2)$ & $0,02(1)$ & 0,0300 \\
\hline $1238,50(7)$ & 1,00 & 1,00 & \\
\hline $1308,50(3)$ & $0,07(1)$ & $0,07(1)$ & 0,0050 \\
\hline $1396,70(8)$ & $0,59(2)$ & $0,58(5)$ & 0,9400 \\
\hline $1453,90(5)$ & $0,32(2)$ & $0,30(2)$ & 0,6400 \\
\hline $1545,20(12)$ & $2,47(24)$ & $2,84(12)$ & 0,0700 \\
\hline $1646,20(11)$ & $8,71(21)$ & $7,46(54)$ & 0,0080 \\
\hline $1650,70(19)$ & $2,47(24)$ & $2,69(20)$ & 0,0080 \\
\hline $1742,30(4)$ & $0,08(1)$ & $0,14(3)$ & 0,0270 \\
\hline $2852,00(2)$ & $0,10(1)$ & $0,08(1)$ & 0,0390 \\
\hline $2922,90(4)$ & $0,44(3)$ & $0,48(9)$ & 0,6570 \\
\hline $2961,70(2)$ & $0,11(1)$ & $0,10(2)$ & 0,6600 \\
\hline $3060,90(5)$ & $0,12(2)$ & $0,19(2)$ & 0,0200 \\
\hline $3187,40(2)$ & $0,08(1)$ & $0,08(1)$ & 1,0000 \\
\hline
\end{tabular}

Tabela 4.4: Valor médio da área das bandas de absorção, onde HeLa corresponde à linhagem de adenocarcinoma de cérvix e HT-29 corresponde à linhagem de adenocarcinoma de cólon. As bandas as quais apresentam um valor de $p$ menor que 0,05 (através do teste t de Student), foram consideradas distintas. A posição do pico de absorção é exibida considerando-se a linhagem HeLa como referência.

A banda de absorção localizada na região de $1239 \mathrm{~cm}^{-1}$ é associada ao modo vibracional de estiramento assimétrico da molécula de $\mathrm{PO}_{2}$, contida nas ligações fosfodiéster. Esta banda de absorção, conforme descrito na sessão 3.3, foi utilizada para a normalização de todo o espectro de absorção visando compensar efeitos relacionados às diferentes espessuras dos filmes contendo células depositadas em cada janela de $\mathrm{CaF}_{2}$.

Observando-se as bandas de absorção relacionadas com a molécula de DNA, notamos que ambas as linhagens celulares estudadas nesta seção apresentam intensidades de absorção distintas, ou seja, as bandas situadas em 918,10(6) $\mathrm{cm}^{-1}$ e 967,20(8) $\mathrm{cm}^{-1}$, as quais estão relacionadas aos anéis de ribose $[2,4]$ e às ligações $\mathrm{C}-\mathrm{C}$ e $\mathrm{C}-\mathrm{O}$ do esqueleto do DNA [41, 2, 4], respectivamente. 
Conforme discutido anteriormente, o fato da linhagem HeLa estar relacionada com o HPV18, gera a hipótese de que a presença do DNA viral seja parcialmente responsável pelo maior valor de áreas das bandas de absorção citadas anteriormente $\left(918,10(6) \mathrm{cm}^{-1}\right.$ e 967,20(8) $\left.\mathrm{cm}^{-1}\right)$, uma vez que através da análise das áreas das bandas de absorção, estamos tendo acesso a uma informação proporcional à quantidade de ligações químicas presentes em uma determinada macromolécula.

Outro ponto interessante é o fato de que a maior parte das bandas de absorção cujas áreas apresentaram diferenças significativas (no caso, 918,10(6) $\mathrm{cm}^{-1}, 967,20(8) \mathrm{cm}^{-1}$, $1084,80(3) \mathrm{cm}^{-1}$ e 1158,70(10) $\left.\mathrm{cm}^{-1}\right)$, estão associadas à ligações do tipo $\mathrm{C}-\mathrm{O}$; os picos de absorção citados levam em consideração a linhagem HeLa como referência.

A banda de absorção localizada na região de $1085 \mathrm{~cm}^{-1}$ está relacionada com os modos vibracionais de estiramento assimétrico, presentes em moléculas contidas nos ácidos nucléicos e no glicogênio [2, 4]. As bandas de absorção relacionadas a tais modos vibracionais encontram-se sobrepostas neste região; é fato que a linhagem celular HeLa possui um nível de glicogênio maior quando comparada com as células do tipo HT-29 [71]. Desta forma, podemos assumir que o decréscimo observado na banda de absorção situada em 1084, 80(3) $\mathrm{cm}^{-1}$ está relacionado ao nível de glicogênio e não às ligações fosfodiésteres $[72,73]$.

A banda de absorção situada em 1158,70(10) $\mathrm{cm}^{-1}$ está relacionada ao estiramento das ligações do tipo $\mathrm{C}-\mathrm{O}$, referentes às moléculas de carboidratos; esta banda de absorção é mais intensa na linhagem celular HeLa uma vez que, conforme discutido anteriormente, a mesma possui um maior nível de glicogênio.

Em diversos estudos relacionados a células neoplásicas, o glicogênio tem sido associado com a proliferação celular acelerada $[74,72,73]$. Uma vez que a linhagem HeLa possui um crescimento anormalmente rápido com relação a outras células tumorais (conforme citado na seção 3.1.1), associamos que este seja um dos motivos pelo qual tal linhagem apresenta maior nível de glicogênio, quando comparada com a linhagem HT-29, por exemplo.

Por fim, as bandas de absorção relacionadas ao estiramento e flexão das moléculas de $\mathrm{CH}_{2}$ e $\mathrm{CH}_{3}$ dos ácidos graxos $\left(13956,70(8) \mathrm{cm}^{-1}, 1453,90(5) \mathrm{cm}^{-1}, 2922,90(4) \mathrm{cm}^{-1} \mathrm{e}\right.$ $\left.2961,70(2) \mathrm{cm}^{-1}\right)$ não sofreram variações consideráveis, dentro da margem estabelecida.

\subsection{Câncer de mama ER+vs. ER-}

O câncer de mama é o tipo de câncer mais freqüentemente diagnosticado em mulheres na faixa dos 40 aos 55 anos [52]; esta é uma doença bastante heterogênea clínica, genética e bioquimicamente.

A grande maioria das mulheres afetadas apresentam uma massa na mama ou alguma anormalidade detectada através da mamografia; aproximadamente 30\% das mulheres 
diagnosticadas, têm chances de desenvolver metástase, a qual em última instância, é fatal [52].

Diferentes características do carcinoma de mama podem ser exploradas, visando estimar o tempo de vida relacionado ao desenvolvimento da doença, além da realização de um prognóstico após o diagnóstico de carcinoma de mama; outro ponto seria avaliar as condições de uma determinada terapia responder de maneira adequada, no caso de cada paciente $[75,37]$.

Além disso, a compreensão das vias sinalizadoras ligadas ao carcinoma de mama, pode contribuir de maneira positiva com relação as abordagens orientadas para a prevenção ou tratamento; a bioquímica envolvida no carcinoma de mama, que em geral se desenvolve nos ductos mamários (Figura 4.12), pode contribuir com informações vitais sob vários aspectos da doença $[76,77,78]$.

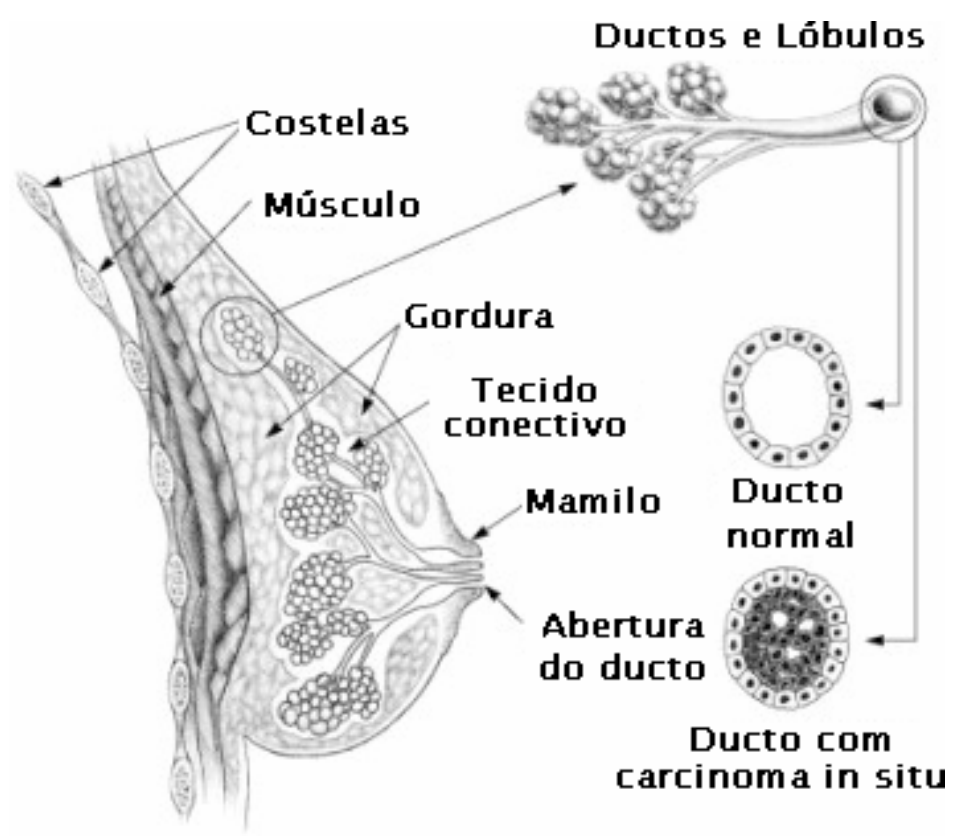

Figura 4.12: Esquema simplificado da mama adulta humana. A mama é composta por ductos lactíferos epiteliais, os quais terminam em alvéolos secretores, imersos em tecido fibrosos e gordura. Os carcinomas de mama, em geral, iniciam seu desenvolvimento no interior dos ductos. Imagem: http://www.wpclipart.com/medical

Alguns tratamentos sistêmicos podem surtir resultados satisfatórios, sendo um caso particular, a terapia ligada aos receptores de estrogênio, os quais estão relacionados com o crescimento e a proliferação do câncer de mama. Os receptores de estrogênio são encontrados em cerca de 50 - 80\% dos tumores mamários [75, 37].

O estrogênio é um hormônio feminino produzido a partir da adolescência se estendendo até a menopausa; o estrogênio é produzido pelo folículo ovariano em maturação, sendo esse hormônio fabricado pelos ovários e liberado na primeira fase do ciclo menstrual. 
Estrogênios induzem diversos efeitos fisiológicos, os quais permitem o desenvolvimento normal e crescimento de tecidos reprodutivos femininos, além da regulação da integridade óssea, função cardiovascular e do sistema nervoso central [75, 37]. A hiperexpressão do estrogênio pode induzir efeitos fisiopatológicos que dão origem ao crescimento de tumores, em especial os tumores de mama.

Tratamentos endócrinos são realizados visando antagonizar os efeitos do estrogênio [37], uma vez que aproximadamente 70 - 80\% de todos os tumores mamários manifesta uma proteína receptora de estrogênio (ER) sendo portanto, este tumor considerado ER positivo $(E R+)$. Estes tumores tendem a crescer mais lentamente, são mais bem diferenciados, e estão associados à um melhor prognóstico global [79]; a expressão dos ER consiste em um dos poucos fatores através dos quais é possível traçar prognósticos, juntamente com o estado linfonodal, tamanho do tumor e grau histológico [75, 37, 38].

Nesta seção, são apresentados os resultados relativos ao estudo das linhagens celulares derivadas de câncer de mama humano: a MCF-7, a qual é caracterizada por possuir receptores de estrogênio expressos $(E R+)$, e a $S K B r 3$, caracterizada pela não-expressão de receptores de estrogênio (ER-). Na figura 4.2(c) foram apresentados os espectros de absorção médios referentes a cada uma das linhagens celulares citadas.

Na figura 4.13 são apresentadas as derivadas de segunda ordem dos espectros de absorção de ambas as linhagens. Através das derivadas, é possível estudarmos a localização dos picos das bandas de absorção de maneira mais precisa [45].

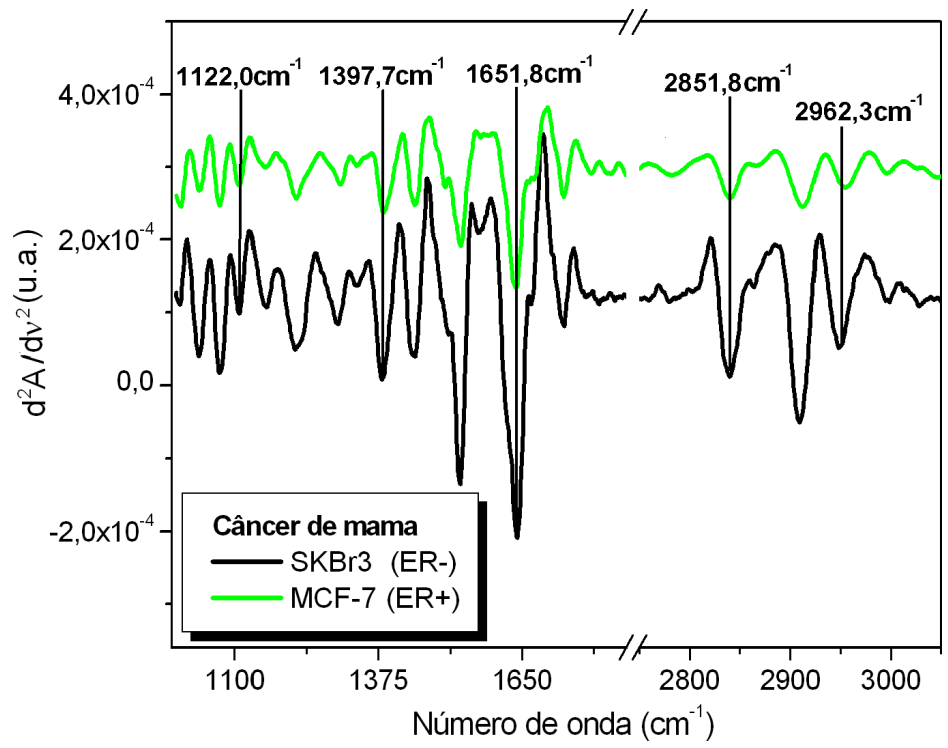

Figura 4.13: Derivadas de segunda ordem do espectro de absorção de ambas as linhagens de câncer de mama; são apresentados os valores do número de onda das bandas de absorção cujos deslocamentos dos picos, de uma linhagem com relação à outra, foram identificados. Os picos de absorção da linhagem SKBr3 foram adotados como referência.

Na tabela 4.5 são apresentados os valores médios e as respectivas incertezas, dos picos 
das bandas de absorção identificadas em cada uma das linhagens celulares estudadas. A associação química e biológica referente a tais picos também é apresentada, nas duas últimas colunas da tabela.

\begin{tabular}{|c|c|c|c|}
\hline \multicolumn{2}{|c|}{ Picos de Abs. $\left(\mathrm{cm}^{-1}\right)$} & \multicolumn{2}{|r|}{ Associação } \\
\hline SKBr3 & MCF-7 & Química & Biológica \\
\hline $1039,80(40)$ & $1042,60(10)$ & $\nu \mathrm{C}-\mathrm{O}$ & Carboidratos \\
\hline $1087,20(18)$ & $1084,80(5)$ & $\nu \mathrm{PO}_{2}$ sim & DNA (lig.fosfodiéster) \\
\hline $1122,00(4)$ & $1120,80(4)$ & $\nu \mathrm{C}-\mathrm{N}$ e $\nu \mathrm{C}-\mathrm{C}$ & RNA \\
\hline $1232,30(14)$ & $1230,20(12)$ & $\nu \mathrm{PO}_{2}$ assim. & DNA (lig.fosfodiéster) \\
\hline $1309,70(12)$ & $1310,60(5)$ & - & Amida III \\
\hline $1397,70(7)$ & $1401,40(13)$ & $\delta \varsigma \mathrm{CH}_{3} \operatorname{sim}$ & Proteínas e lipídeos \\
\hline $1454,50(16)$ & $1454,80(5)$ & $\delta \varsigma \mathrm{CH}_{3}$ assim. & Proteínas e lipídeos \\
\hline $1543,30(11)$ & $1542,60(10)$ & $\delta \mathrm{N}-\mathrm{H}$ e $\nu \mathrm{C}-\mathrm{N}$ & Amida II \\
\hline $1641,30(18)$ & $1643,80(98)$ & $\nu \mathrm{C}=\mathrm{O}$ & Configuração $\beta$ - Amida I \\
\hline $1651,80(83)$ & $1650,00(63)$ & $\nu \mathrm{C}=\mathrm{O}$ & $\alpha$ hélice - Amida I \\
\hline $1740,70(3)$ & $1742,20(10)$ & $\nu \mathrm{C}=\mathrm{O}$ & Lipídeos (sebo) \\
\hline $2851,80(9)$ & $2854,00(9)$ & $\nu \mathrm{CH}_{2} \operatorname{sim}$ & Ácidos graxos \\
\hline $2924,30(17)$ & $2923,20(4)$ & $\nu \mathrm{CH}_{2}$ assim. & Ácidos graxos \\
\hline $2962,30(6)$ & $2964,60(7)$ & $\nu \mathrm{CH}_{3}$ assim. & Cadeias acila (lipídeos) \\
\hline $3072,30(40)$ & $3047,60(73)$ & $\nu \mathrm{CH}_{3}$ sim. & Cadeias acila (lipídeos) \\
\hline - & $3166,00(49)$ & $\nu \mathrm{N}-\mathrm{H}$ sim. & Subestruturas "cis" ordenadas \\
\hline
\end{tabular}

Tabela 4.5: Principais bandas de absorção referentes às linhagens celulares de câncer de mama humano, com receptores de estrogênio positivo (MCF-7) e receptores de estrogênio negativo $\mathrm{SKBr}$, cujas associações químicas e biológicas foram obtidas a partir de diversos trabalhos $[2,41,3,4,46,48,49]$. Os símbolos empregados na coluna referente à associação química estão relacionados aos modos vibracionais de estiramento $(\nu)$, modo vibracional de tesoura $(\varsigma)$, modo vibracional de flexão $(\delta)$, movimentos simétricos $($ sim. e assimétricos (assim.).

Através de testes estatísticos, foram verificados os deslocamentos significativos dos picos das bandas de absorção de uma linhagem com relação à outra; para tal verificação, foi considerado o teste t de Student, com intervalo de rejeição de $p>0,05$. 
Foram observados deslocamentos significativos dos picos situados nas regiões próximas à $1122 \mathrm{~cm}^{-1}, 1397 \mathrm{~cm}^{-1}, 1651 \mathrm{~cm}^{-1}, 2851 \mathrm{~cm}^{-1}, 2962 \mathrm{~cm}^{-1}$ e $3072 \mathrm{~cm}^{-1}$. O deslocamento apresentado na região de $1122 \mathrm{~cm}^{-1}$ está relacionado com as moléculas de RNA; o deslocamento do pico situado em $1397,70(7) \mathrm{cm}^{-1}$ pode ser associado aos modos vibracionais de estiramento e flexão simétricas das moléculas de $\mathrm{CH}_{3}$, encontradas nas proteínas e lipídeos. O deslocamento do pico da banda de absorção associada à amida I será discutido posteriormente, na seção 4.5 .

A região compreendida entre $2850 \mathrm{~cm}^{-1}$ e $3075 \mathrm{~cm}^{-1}$, conforme apresentado na seção 4, pode ser associada aos modos vibracionais referentes aos lipídeos. Os picos das bandas de absorção situados em 2851,80(9) $\mathrm{cm}^{-1}$ e 2962,030(6) $\mathrm{cm}^{-1}$ podem ser associados ao estiramento simétrico e assimétrico das moléculas de $\mathrm{CH}_{2}$ e $\mathrm{CH}_{3}$, respectivamente; por fim, o pico situado em cerca de $3072 \mathrm{~cm}^{-1}$, pode ser associado às cadeias do tipo "acila", também contidas nos lipídeos.

Uma vez identificadas as bandas de absorção presentes nas amostras, a área média de cada uma das bandas foi calculada. Novamente, o teste estatístico t de Student foi realizado no intuito de compararmos as linhagens celulares estudadas, verificando quais bandas apresentaram uma área significantemente distinta, considerando-se novamente o intervalo de rejeição $p>0,05$. Os valores das áreas médias de cada banda de absorção e suas incertezas são apresentados na tabela 4.6, assim como os respectivos valores de $p$.

\begin{tabular}{|c|c|c|c|}
\hline Picos de Abs. $\left(\mathrm{cm}^{-1}\right)$ & SKBr3 & MCF-7 & p \\
\hline \hline $1039,80(40)$ & $0,35(12)$ & $0,11(1)$ & 0,040 \\
\hline $1087,20(18)$ & $0,17(4)$ & $0,29(8)$ & 0,020 \\
\hline $1122,00(4)$ & $0,08(2)$ & $0,10(2)$ & 0,400 \\
\hline $1232,30(14)$ & 1,00 & 1,00 & - \\
\hline $1309,70(12)$ & $0,18(15)$ & $0,13(1)$ & 0,410 \\
\hline $1397,70(7)$ & $1,02(17)$ & $1,36(16)$ & 0,007 \\
\hline $1454,50(16)$ & $0,50(2)$ & $0,30(3)$ & 0,340 \\
\hline $1543,30(11)$ & $2,21(28)$ & $4,15(55)$ & 0,010 \\
\hline $1641,30(18)$ & $10,99(86)$ & $14,13(85)$ & 0,640 \\
\hline $1651,80(83)$ & $1,22(28)$ & $3,25(55)$ & 0,004 \\
\hline $1740,70(3)$ & $0,18(6)$ & $0,14(4)$ & 0,540 \\
\hline $2851,80(9)$ & $0,37(5)$ & $0,24(7)$ & 0,160 \\
\hline $2924,30(17)$ & $0,59(10)$ & $0,34(2)$ & 0,010 \\
\hline & & & \\
\hline & & & \\
\hline & & &
\end{tabular}

(continua na próxima página) 


\begin{tabular}{|c|c|c|c|}
\hline Picos de Abs. $\left(\mathrm{cm}^{-1}\right)$ & SKBr3 & MCF-7 & p \\
\hline \hline $2962,30(6)$ & $0,44(25)$ & $0,14(2)$ & 0,250 \\
\hline $3072,30(40)$ & $0,43(14)$ & $0,44(8)$ & 0,920 \\
\hline
\end{tabular}

Tabela 4.6: Valor médio da área das bandas de absorção, onde MCF-7 corresponde à linhagem de câncer de mama com receptores de estrogênio positivos e SKBr3 corresponde à linhagem com receptores de estrogênio negativos. As bandas as quais apresentam um valor de $p$ menor que 0,05 (através do teste t de Student), foram consideradas distintas. A posição do pico de absorção é exibida considerando-se a linhagem MCF-7 como referência.

As bandas de absorção situadas na região próximas a $1040 \mathrm{~cm}^{-1}, 1087 \mathrm{~cm}^{-1}, 1398 \mathrm{~cm}^{-1}$, $1543 \mathrm{~cm}^{-1}, 1652 \mathrm{~cm}^{-1}$ e $2924 \mathrm{~cm}^{-1}$ apresentaram valores significativamente distintos, de acordo com o teste t de Student $(p<0,05)$ realizado. É possível observar que a área média das bandas de absorção referentes às proteínas $\left(1397,70(7) \mathrm{cm}^{-1}, 1543,30(11) \mathrm{cm}^{-1}\right.$ e $1651,80(83) \mathrm{cm}^{-1}$ ) é maior no caso da linhagem MCF-7, ou seja, a linhagem celular que possui receptores de estrogênio expressos. A área média da banda de absorção associada ao DNA $\left(1087,20(18) \mathrm{cm}^{-1}\right)$ também é maior na linhagem MCF-7.

Para discutirmos estes resultados, faz-se necessário um melhor entendimento da bioquímica envolvida no câncer de mama. O crescimento e desenvolvimento da mama normal são regulados pela interação de diversos hormônios (estrogênio, progesterona, andrógenos, hormônios da tireóide, IGF-1, IGF-2 e fatores de crescimento epidérmicos - ou EGF) e fatores de crescimento (FC), secretados pelas células mamárias, as quais possuem funções autócrinas, ou seja, secretam substâncias as quais atingem ela mesma.

O estradiol, é um hormônio sexual produzido pelos folículos ovarianos; este hormônio desempenha um papel importante na regulação da morfologia e crescimento das células tumorais,uma vez que regula a expressão de diversos genes ligados àa peptídeos e proteínas envolvidas nos mecanismos de controle de crescimento das células mamárias. Os efeitos destes hormônios e fatores de crescimento são ajustados pela ligação com receptores específicos, situados na membrana celular, por exemplo.

Estas interações regulam a cascata metabólica de sinais bioquímicos intracelulares, resultando na ativação ou supressão de diversos genes. Desta forma, o tecido normal de mama é regulado por estes hormônios, fatores de crescimento e seus receptores, não sendo uma surpresa que as células malignas derivadas do tecido mamário também possuam uma certa dependência hormonal.

Aberrações genéticas relacionadas às vias sinalizadoras dos fatores de crescimento estão ligadas ao desenvolvimento do câncer de mama [38, 79, 37]. A regulação dos fatores de crescimento em células de câncer de mama, assim como sua atividade hormonal é apresentada no esquema da figura 4.14. 


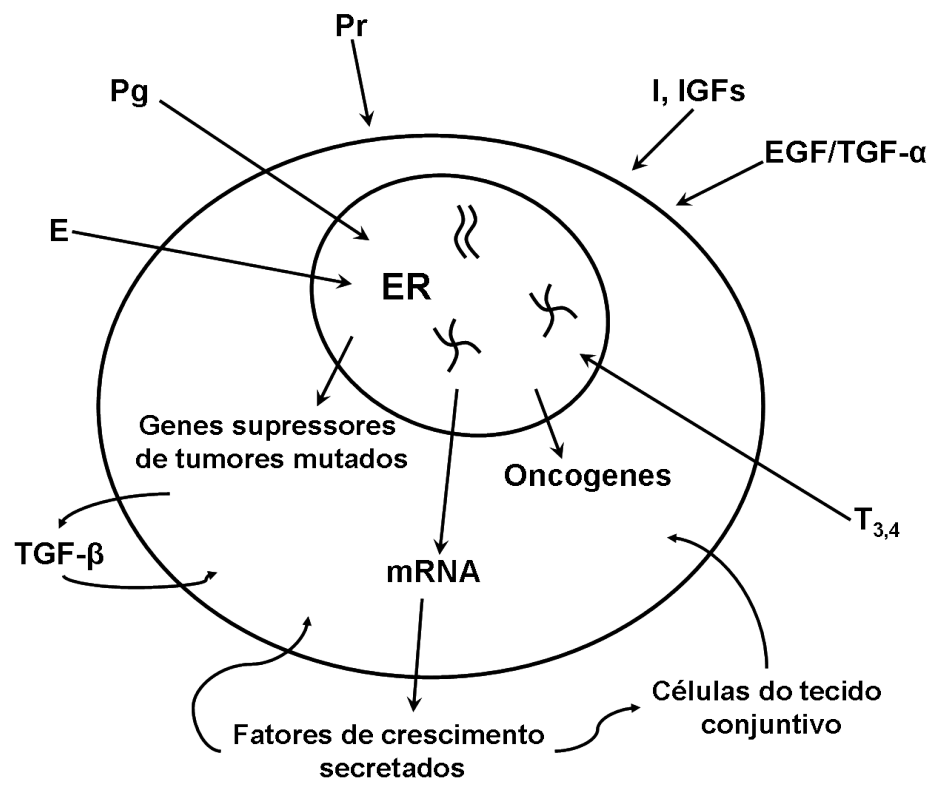

Figura 4.14: Regulação do crescimento do câncer de mama devido a hormônios e fatores de crescimento. E=estrogênio; $\mathrm{Pg}=$ progesterona; $\mathrm{Pr}=$ prolactina; I=insulina; IGF's=Fatores de crescimento do tipo insulina; $E G F=$ fatores de crescimento epidérmicos; TGF- $\alpha=$ fator de crescimento transformante alfa; $T_{3,4}=$ hormônios da tireóide; TGF- $\beta=$ fator de crescimento transformante beta. Imagem: adaptada de R.C. Bast, Cancer and Medicine, 2000.

Diversos estudos [80, 81, 79] sugerem que as células de câncer de mama, sob o controle dos estrogênios, podem sintetizar e secretar seus próprios fatores de crescimento os quais podem auto-estimular as células de câncer de mama ou células adjacentes do tecido conjuntivo, através de mecanismos autócrinos ou parácrinos.

O tecido adiposo pode secretar fatores de crescimento, tais como o IGF-1 e IGF-2, os quais podem estimular células do câncer de mama, uma vez que os mesmos induzem um grande potencial mitógeno ao epitélio que compõe o tumor.

Diversos peptídeos, os quais possuem uma atividade autócrina inibitória também são secretados por células de câncer de mama. O TGF- $\beta$ é uma família de fatores de crescimento a qual inibe a proliferação de tecido epitelial e estimula a proliferação de tecido conjuntivo. Estudos sugerem que as células as quais não apresentam expressão de receptores de estrogênio (ER-), são mais sensíveis ao TGF- $\beta$ do que as células cujos receptores de estrogênio estão expressos $(E R+)$.

O potencial de malignidade do câncer de mama é dependente do balanço entre estimuladores de crescimento e inibidores de crescimento, produzidos pelos tumores. Em células de câncer de mama ER+, a expressão e secreção de certos fatores de crescimento autócrinos, tais como o TGF- $\alpha$ e IGF-2, são estimulados por estrogênios. Estrogênios estimulam a síntese de RNA, DNA e proteínas, além de desempenharem uma atividade chave na regulação enzimática [82]. 
Desta forma, podemos supor que as alterações observadas com relação às áreas e deslocamentos dos picos das bandas de absorção referentes às proteínas, ao DNA e RNA, estão também ligadas à expressão do estrogênio; embora este fato não possa ser responsabilizado pela totalidade das alterações verificadas, pode-se supor que células que possuem o estrogênio expresso são capazes de sintetizar certos tipos de biomoléculas, acarretando num aumento da quantidade de genes e proteínas e, conseqüentemente, este aumento acarreta um aumento no valor médio das áreas das bandas de absorção relacionadas com as proteínas, com o DNA e com o RNA. No caso das áreas das bandas referentes às proteínas, é possível observar um valor quase duas vezes maior quando comparamos a linhagem MCF-7 (ER+), com a linhagem SKBr3 (ER-).

Observando-se os resultados apresentados nas tabelas 4.5 e 4.6, é possível verificar um deslocamento significativo de três picos de absorção situados na região dos lipídeos $\left(2851,80(9) \mathrm{cm}^{-1}, 2962,30(6) \mathrm{cm}^{-1}\right.$ e 3072,30(40) $\left.\mathrm{cm}^{-1}\right)$; além disso, a área média da banda de absorção situada em 2924,30(17) $\mathrm{cm}^{-1}$, é cerca de quatro vezes maior no caso da linhagem SKBr3 (ER-). As demais áreas das bandas de absorção da linhagem SKBr3, referentes aos lipídeos, embora não sejam significativamente distintas (de acordo com o teste t de Student realizado), também apresentam uma maior área quando comparada com as áreas calculadas para a linhagem MCF-7.

Tais resultados podem ser explicados através das seguintes suposições: de acordo com a literatura $[83,84,85]$, há uma relação entre o grau do câncer de mama e a atividade da colina quinase (ChoK), a qual é uma enzima que catalisa a reação química entre a ATP e a colina gerando a fosfatidilcolina (PCho).

A fosfatidilcolina é uma lipoproteína encontrada nas membranas celulares; sua concentração e composição parecem influir diretamente na integridade e funcionamento das membranas,e principalmente, no transporte através delas [85].

Como a atividade da colina quinase está associada à cânceres de mama do tipo ER- [83, 84], a linhagem SKBr3 possui a expressão da colina quinase aumentada; sendo assim, supomos que haja uma maior produção de fosfatidilcolina, ou seja, uma molécula lipídica. Uma vez que há uma maior produção de fosfatidilcolina, podemos associá-la ao aumento das áreas das bandas de absorção relacionadas à região dos lipídeos. Diversas alterações ocorrem em células neoplásicas, sendo as suposições apresentadas apenas uma das hipóteses que poderiam ser consideradas na tentativa de explicar tais alterações observadas.

\subsection{Leucemia Tipo T vs. Linfócitos T}

O tecido sangüíneo possui natureza conjuntiva, sendo constituído de plasma e glóbulos sangüíneos. Dentre suas principais funções, estão o transporte de nutrientes, oxigênio, neurotransmissores, hormônios e imunoglobulinas, além de substâncias tóxicas para 
serem eliminadas, além de exercer, papéis relacionados à defesa imunológica e coagulação.

O plasma possui uma coloração amarelada, sendo constituído de cerca de $92 \%$ de água, $7 \%$ das proteínas albumina, globulina e fibrinogênio, e cerca de $1 \%$ de glicose, lipídeos, enzimas, vitaminas e hormônios [31]. Essas proteínas são responsáveis em auxiliar a regulação osmótica, reações do sistema imune e a coagulação sangüínea. O plasma efetua trocas de materiais com o líquido intracelular das células do sangue e, também, como o líquido intersticial [32].

Os glóbulos sangüíneos têm sua origem no tecido reticular, ou hematopoiético, sendo as hemácias as células existentes em maiores quantidades. Estas, também denominadas eritrócitos (ou glóbulos vermelhos), possuem formato de discos bicôncavos e apresentamse, em nossa espécie, sem núcleos - portanto, sem DNA. Transportam oxigênio vindo dos pulmões para os tecidos corporais e gás carbônico no sentido inverso. A hemoglobina, presente nessas células, dão ao sangue sua cor característica.

Os leucócitos, ou células brancas, possuem um diâmetro aproximado de 15-20 $\mu \mathrm{m}$, enquanto que o diâmetro médio das hemácias varia entre $6 \mu \mathrm{m}$ e 8,5 $\mu \mathrm{m}$ [31]. Os leucócitos são responsáveis pelo ataque e destruição de agentes invasores; existem cinco tipos de leucócitos: neutrófilo, eosinófilo e basófilo (granulócitos), linfócito e monócito (agranulócitos).

Finalmente, as plaquetas (ou trombócitos) são partículas pequenas, constituídas de fragmentos de células chamadas megacariócitos, oriundas da medula óssea e baço. São, também, responsáveis pela coagulação sanguínea. Um esquema, ilustrando a origem de cada uma das células que compõem o tecido sanguíneo, é apresentado na figura 4.15.

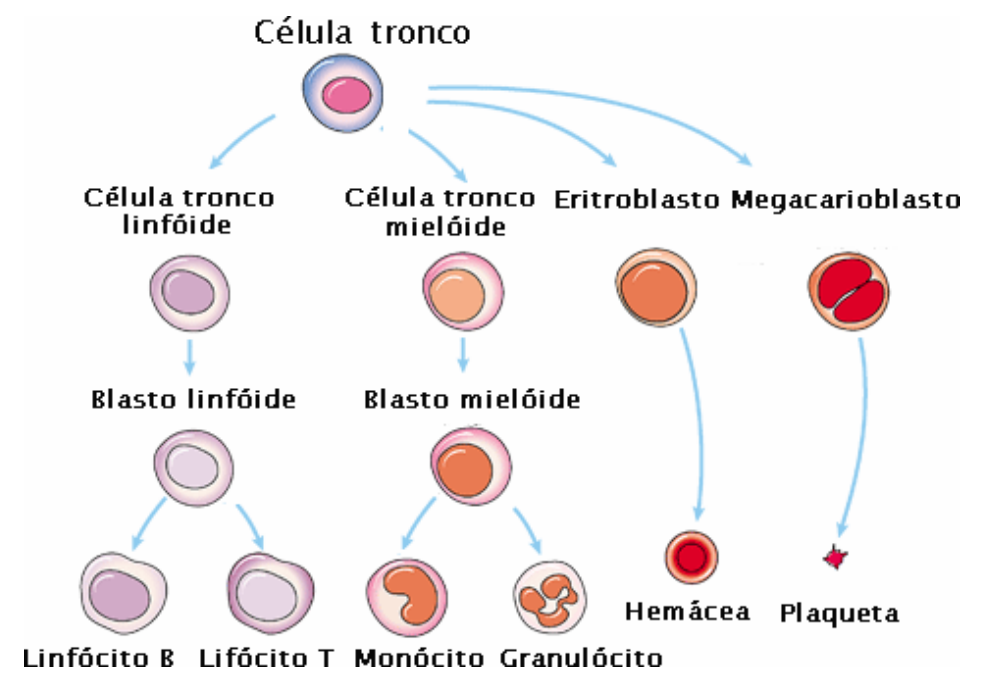

Figura 4.15: As células tronco dividem-se e seguem caminhos de desenvolvimento distintas, que resultam em diferentes tipos de células sangüíneas e plaquetas. Neste diagrama, várias formas intermediárias foram omitidas. Imagem: http://www.wpclipart.com/ medical/index.html 
A leucemia é uma doença maligna dos leucócitos, cuja origem na maioria das vezes, não é conhecida. Ela tem como principal característica o acúmulo de células jovens (blásticas) anormais na medula óssea, as quais substituem as células sangüíneas normais. $\mathrm{Na}$ medula óssea são encontradas as células tronco ou precursoras, que originam os elementos figurados do sangue (conforme apresentado na figura 4.15).

Os principais sintomas da leucemia decorrem do acúmulo dessas células na medula óssea, prejudicando ou impedindo a produção dos glóbulos vermelhos (causando anemia), dos glóbulos brancos (causando infecções) e das plaquetas (causando hemorragias).

Depois de instalada, a doença progride rapidamente, exigindo com isso que o tratamento seja iniciado logo após o diagnóstico e a classificação da leucemia [37].

Segundo as estimativas de incidência de câncer no Brasil, as leucemias atingirão cerca de 5330 homens e 4220 mulheres no ano de 2009 [86]. O tipo de leucemia mais freqüente em crianças é a leucemia linfóide aguda (ou linfoblástica); já a leucemia mielóide aguda é mais comum em adultos.

A linhagem celular JURKAT consiste em células comumente utilizadas no estudo da leucemia tipo T (mielóide aguda). Nesta seção serão apresentados os resultados referentes à caracterização desta linhagem celular, os quais foram comparados com células sadias (PBMC), extraídas do sangue de doadores voluntários saudáveis.

A caracterização de ambas as linhagens foi conduzida através da identificação das bandas de absorção existentes nos espectros apresentados no início do presente capítulo.

A definição da região a qual situavam-se os picos das bandas de absorção foi realizada através do cálculo da derivada de segunda ordem dos espectros de absorção. Na figura 4.16 são apresentadas as derivadas de segunda ordem para ambas as linhagens celulares.

Na tabela 4.7 são apresentados os valores médios obtidos para cada pico de absorção; através do teste t de Student (considerando-se $p>0,05$ como sendo intervalo de rejeição), foram verificadas se as diferenças observadas eram estatisticamente significativas. 


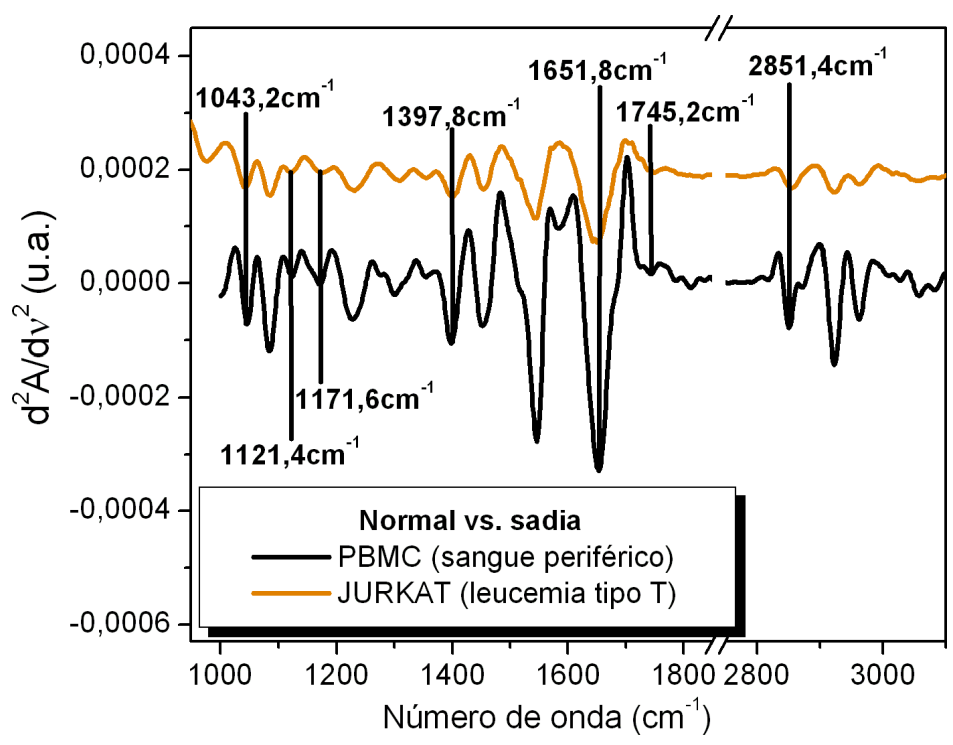

Figura 4.16: Derivadas de segunda ordem do espectro de absorção das amostras de leucemia e células mononucleares de sangue periférico humano; são apresentados os valores do número de onda das bandas de absorção cujos deslocamentos dos picos, de uma linhagem com relação à outra, foram identificados. Os picos de absorção da linhagem PBMC foram adotados como referência.

Além dos picos todas as bandas identificadas, são apresentadas associações químicas e biológicas referentes a cada região. Os picos de absorção os quais apresentaram um deslocamento significativo foram: 1233, 80(28) $\mathrm{cm}^{-1}, 1310,60(9) \mathrm{cm}^{-1}, 1348,20(32) \mathrm{cm}^{-1}$, $3062,20(47) \mathrm{cm}^{-1}$ e $3184,00(34) \mathrm{cm}^{-1}$, cujos valores citados consideram os picos relacionados à linhagem JURKAT como referência.

\begin{tabular}{|l|c|c|c|}
\hline \multicolumn{2}{|c|}{ Picos de Abs. $\left(\mathrm{cm}^{-1}\right)$} & \multicolumn{2}{c|}{ Associação } \\
\hline JURKAT & PBMC & Química & Biológica \\
\hline \hline $1043,20(25)$ & $1046,50(7)$ & $\nu \mathrm{C}-\mathrm{O}$ & Carboidratos \\
\hline $1084,80(10)$ & $1084,80(9)$ & $\nu \mathrm{PO}_{2}$ sim. & DNA (lig.fosfodiéster) \\
\hline $1121,40(9)$ & - & $\nu \mathrm{C}-\mathrm{N}$ e $\nu \mathrm{C}-\mathrm{C}$ & RNA \\
\hline $1171,60(14)$ & - & $\nu \mathrm{C}-\mathrm{O}$ & Serina,tirosina e carboidratos \\
\hline $1233,80(28)$ & $1229,20(8)$ & $\nu \mathrm{PO}_{2}$ assim. & DNA (lig.fosfodiéster) \\
\hline $1310,60(9)$ & $1300,30(60)$ & - & Amida III \\
\hline $1348,20(32)$ & $1358,70(26)$ & $\nu \mathrm{C}-\mathrm{O}$ sim. e C-Hsim. & Proteínas \\
\hline
\end{tabular}




\begin{tabular}{|c|c|c|c|}
\hline \multicolumn{2}{|c|}{ Picos de Abs. $\left(\mathrm{cm}^{-1}\right)$} & \multicolumn{2}{|c|}{ Associação } \\
\hline JURKAT & PBMC & Química & Biológica \\
\hline - & $1364,20(13)$ & $\nu \mathrm{C}-\mathrm{O}$ sim. e $\mathrm{C}-\mathrm{H} s i m$. & Proteínas \\
\hline $1397,80(8)$ & $1397,50(8)$ & $\delta \varsigma \mathrm{CH}_{3} \operatorname{sim}$ & Proteínas e lipídeos \\
\hline $1453,20(10)$ & $1454,70(7)$ & $\delta \varsigma \mathrm{CH}_{3}$ assim. & Proteínas e lipídeos \\
\hline $1542,60(9)$ & $1544,30(7)$ & $\delta \mathrm{N}-\mathrm{H}$ e $\nu \mathrm{C}-\mathrm{N}$ & Amida II \\
\hline $1642,60(90)$ & $1644,30(67)$ & $\nu \mathrm{C}=\mathrm{O}$ & Configuração $\beta$ - Amida I \\
\hline $1651,80(20)$ & $1652,20(18)$ & $\nu \mathrm{C}=\mathrm{O}$ & $\alpha$ hélice - Amida I \\
\hline $1745,20(12)$ & - & $\nu \mathrm{C}=\mathrm{O}$ & Lipídeos (sebo) \\
\hline $2851,40(12)$ & $2853,00(4)$ & $\nu \mathrm{CH}_{2}$ sim. & Ácidos graxos \\
\hline $2903,20(20)$ & $2922,80(6)$ & $\nu \mathrm{CH}_{2}$ assim. & Ácidos graxos \\
\hline $2962,20(5)$ & $2963,00(4)$ & $\nu \mathrm{CH}_{3}$ assim. & Cadeias acila (lipídeos) \\
\hline $3062,20(47)$ & $3070,30(53)$ & $\nu \mathrm{CH}_{3}$ sim. & Cadeias acila (lipídeos) \\
\hline $3184,00(34)$ & $3173,50(21)$ & $\nu \mathrm{N}-\mathrm{H} \operatorname{sim}$ & Subestruturas "cis" ordenadas \\
\hline
\end{tabular}

Tabela 4.7: Principais bandas de absorção referentes às linhagens celulares de leucemia humana do tipo $\mathrm{T}$ (JURKAT) e células mononucleares de sangue periférico humano PBMC, cujas associações químicas e biológicas foram obtidas a partir de diversos trabalhos $[2,41,3,4,46,48,49]$. Os símbolos empregados na coluna referente à associação química estão relacionados aos modos vibracionais de estiramento $(\nu)$, modo vibracional de tesoura $(\varsigma)$, modo vibracional de flexão $(\delta)$, movimentos simétricos (sim.) e assimétricos (assim.).

O pico de absorção situado na região de $1233 \mathrm{~cm}^{-1}$ está relacionado ao estiramento simétrico das moléculas de $\mathrm{PO}_{2}$ situadas nas ligações fosfodiéster do DNA. Os picos de absorção localizados em cerca de $1310 \mathrm{~cm}^{-1}$ e $1348 \mathrm{~cm}^{-1}$ estão associados aos modos vibracionais das proteínas; por fim, também foram observados deslocamentos significativos na região dos lipídeos, mais precisamente na região das bandas de absorção situadas em $3062,20(47) \mathrm{cm}^{-1}$ e $3184,00(34) \mathrm{cm}^{-1}$.

Uma vez identificadas as bandas de absorção, a área referente a cada uma delas foi calculada e os valores médios das áreas das bandas de cada uma das linhagens celulares estudadas são apresentados na tabela 4.8. Novamente, através do teste t de Student foi feita a avaliação das diferenças encontradas, verificando-se se as mesmas eram significativas estatisticamente ou não; os valores apresentados na primeira coluna, relacionados com a localização das bandas, são referentes à linhagem JURKAT a qual foi adotada 
como referência.

$\mathrm{Na}$ segunda e terceira colunas são apresentados os valores médios das áreas e suas respectivas incertezas; na última coluna, os valores de $p$ obtidos são apresentados; vale lembrar que o teste $\mathrm{t}$ de Student foi realizado considerando-se $p>0,05$ como intervalo de rejeição.

\begin{tabular}{|c|c|c|c|}
\hline Picos de Abs. $\left(\mathrm{cm}^{-1}\right)$ & JURKAT & PBMC & $\mathrm{p}$ \\
\hline $1043,20(25)$ & $0,30(1)$ & $0,15(3)$ & 0,020 \\
\hline $1084,80(10)$ & $0,45(8)$ & $0,38(2)$ & 0,930 \\
\hline $1121,40(9)$ & $0,03(1)$ & - & - \\
\hline $1171,60(14)$ & $0,03(1)$ & - & - \\
\hline $1233,80(28)$ & 1,00 & 1,00 & - \\
\hline $1310,60(9)$ & $0,51(14)$ & $0,37(16)$ & 0,581 \\
\hline $1348,20(32)$ & $0,03(1)$ & $0,58(11)$ & 0,581 \\
\hline $1397,80(8)$ & $0,02(1)$ & $0,10(15)$ & 0,045 \\
\hline $1453,20(10)$ & $0,08(1)$ & $0,19(6)$ & 0,229 \\
\hline $1542,60(9)$ & $2,89(21)$ & $2,99(17)$ & 0,920 \\
\hline $1642,60(90)$ & $10,81(57)$ & $16,69(83)$ & 0,009 \\
\hline $1651,80(20)$ & $2,89(15)$ & $0,99(5)$ & 0,003 \\
\hline $1745,20(12)$ & $0,03(1)$ & - & - \\
\hline $2851,40(12)$ & $0,01(1)$ & $0,06(1)$ & 0,030 \\
\hline $2903,20(20)$ & $0,10(2)$ & $0,20(7)$ & 0,123 \\
\hline $2962,20(5)$ & $0,02(1)$ & $0,04(1)$ & 0,510 \\
\hline $3062,20(47)$ & $0,06(1)$ & $0,22(4)$ & 0,301 \\
\hline $3184,00(34)$ & $0,20(11)$ & $0,25(9)$ & 0,241 \\
\hline
\end{tabular}

Tabela 4.8: Valor médio da área das bandas de absorção, onde JURKAT corresponde à linhagem celular de leucemia humana do tipo T e PBMC, corresponde às células mononucleares de sangue periférico humano. As bandas as quais apresentam um valor de $p$ menor que 0,05 (obtidos através do teste $t$ de Student), foram consideradas distintas. A posição do pico de absorção é exibida considerando-se a linhagem JURKAT como referência.

Observando-se os valores apresentados na tabela 4.8, é possível notar que as bandas 
de absorção situadas nas regiões próximas a $1043 \mathrm{~cm}^{-1}, 1121 \mathrm{~cm}^{-1}, 1171 \mathrm{~cm}^{-1}, 1397 \mathrm{~cm}^{-1}$, $1642 \mathrm{~cm}^{-1}, 1651 \mathrm{~cm}^{-1}, 1745 \mathrm{~cm}^{-1}$ e $2851 \mathrm{~cm}^{-1}$ apresentaram diferenças significativas com relação às áreas.

As bandas referentes àa amida I $\left(1642,60(90) \mathrm{cm}^{-1}\right.$ e $\left.1651,80(20) \mathrm{cm}^{-1}\right)$ não apresentaram um deslocamento significativo de uma linhagem com relação à outra; as células normais (PBMC) apresentaram uma maior área, tanto com relação à configuração $\beta$, quanto com relação à estrutura $\alpha$-hélice; outros aspectos relacionados à banda de absorção da amida I serão discutidos na seção 4.17(b).

A banda de absorção localizada em cerca de $1397 \mathrm{~cm}^{-1}$, associada à região das proteínas, indica que no caso de células leucêmicas o número de moléculas que contém carboxilato aumenta, uma vez que a área da mesma é maior quando comparada com as células sadias; tal fato já foi apresentado por diversos trabalhos [87, 88, 89]. Ainda com relação às bandas referentes às proteínas e ao DNA $\left(1043,20(25) \mathrm{cm}^{-1}, 1171,60(14) \mathrm{cm}^{-1}\right.$, $1397,80(8) \mathrm{cm}^{-1}, 1745,20(12) \mathrm{cm}^{-1}$ e $\left.2851,40(12) \mathrm{cm}^{-1}\right)$, podemos notar que as áreas das bandas de absorção referentes aos modos vibracionais dos grupos fosfatos, situadas em $1043,20(25) \mathrm{cm}^{-1}$ e 1084, 80(10) $\mathrm{cm}^{-1}$, aumentam no caso da leucemia. Os cromossomos das células leucêmicas podem ser erroneamente modificados e expressos em um número maior de cópias; anormalidades cromossômicas ocorrem em cerca de 56 - 65\% dos pacientes, sendo o aumento observado nas bandas de absorção citadas, são compatíveis com as características da doença.

Translocações cromossômicas no gene blc-2 são comuns em células de leucemia, e a linhagem JURKAT não é uma exceção; altos níveis da proteína BCL-2 são notados em cerca de $85 \%$ dos casos de leucemia do tipo T [37]. A hipo-metilação da região promotora do gene bcl-2 foi encontrada em quase todos os casos os quais apresentaram altos níveis de proteína BCL-2. A proteína BCL-2 é uma conhecida supressora de apoptose [37], sendo que a alta concentração das mesmas resulta em uma longevidade dos linfócitos leucêmicos, resultando num aumento progressivo acumulativo destas células. Com isso, podemos supor que o aumento observado nas áreas das bandas de absorção da linhagem JURKAT, situadas em 1043, 20(25) $\mathrm{cm}^{-1}, 1171,60(14) \mathrm{cm}^{-1}$ e 1397, 80(8) $\mathrm{cm}^{-1}$ estão fortemente associadas, por exemplo, às translocações existentes no gene blc-2 e conseqüentemente à hiperexpressão da proteína BCL-2, embora deva ser lembrado que estas consistem em apenas uma alteração relacionada à leucemia; diversas proteínas e genes são alterados ao longo de todo o processo neoplásico.

Finalmente, um ponto interessante a ser discutido é com relação às diferenças observadas na região das bandas de absorção referentes aos lipídeos. As bandas situadas na região de $3062 \mathrm{~cm}^{-1}$ e $3184 \mathrm{~cm}^{-1}$ apresentaram um deslocamento significativo dos picos de absorção, ao passo que as bandas situadas em cerca de $1745 \mathrm{~cm}^{-1}$ e $2875 \mathrm{~cm}^{-1}$ apresentaram diferenças com relação às áreas.

De acordo com os dados apresentados na tabela 4.8, as áreas das bandas situadas 
na região compreendida entre $2850 \mathrm{~cm}^{-1}$ e $3190 \mathrm{~cm}^{-1}$ possuem um valor menor no caso da linhagem JURKAT; esta característica contrasta com o observado em diversas células e tecidos tumorais, os quais em geral apresentam maiores quantidades de ligações covalentes associadas a estruturas lipídicas, e conseqüentemente, associadas a membrana celular, quando comparadas com tecidos ou células sadias da referida doença. O fato das células leucêmicas possuírem menores concentrações de lipídeos, nos leva a supor que esta diferença está relacionada com uma maior fragilidade da membrana celular das mesmas, ou seja, estão associadas com a presença de células "smudge", ou "manchadas".

Este tipo de células pode ser originado a partir de danos durante manipulação das mesmas, devido à ruptura das paredes celulares, as quais quando observadas ao microscópio, parecem com uma mancha, daí o termo células "manchadas". No entanto, estas células são vistas com muito mais freqüência em pacientes portadores de leucemias. Por exemplo, em indivíduos normais, é comum a ocorrência de cerca de 0,01\% destas células, ao passo que em pessoas portadoras de leucemia aguda, este número varia entre 1 a $3 \%$, podendo chegar a $20 \%$ [37].

Na tabela 4.9 são apresentados os valores médios das áreas de algumas bandas de aborção associadas aos lipídeos; é importante salientar que as células sadias (PBMC) possuem um valor médio menor do que as linhagens neoplásicas estudadas, sendo a linhagem JURKAT a única exceção, conforme discutido anteriormente.

\begin{tabular}{|c|l|l|l|l|l|l|l|}
\hline Picos $\left(\mathrm{cm}^{-1}\right)$ & PBMC & B16F10 & C8161 & HeLa & HT-29 & MCF-7 & SKBr3 \\
\hline \hline 1395 & $0,10(15)$ & $0,52(4)$ & $0,53(2)$ & $0,58(2)$ & $0,59(5)$ & $1,36(16)$ & $1,02(17)$ \\
\hline 1496 & $0,19(6)$ & $0,36(4)$ & $0,29(3)$ & $0,32(2)$ & $0,30(2)$ & $0,30(3)$ & $0,50(2)$ \\
\hline 1739 & - & $0,12(6)$ & $0,08(1)$ & $0,08(1)$ & $0,14(3)$ & $0,14(4)$ & $0,18(6)$ \\
\hline 2851 & $0,06(1)$ & $0,16(2)$ & $0,10(2)$ & $0,10(1)$ & $0,08(1)$ & $0,24(7)$ & $0,37(5)$ \\
\hline 2920 & $0,20(7)$ & $0,46(1)$ & $0,26(3)$ & $0,44(3)$ & $0,48(9)$ & $0,34(2)$ & $0,59(10)$ \\
\hline 2960 & $0,04(1)$ & $0,10(6)$ & $0,20(9)$ & $0,11(1)$ & $0,10(2)$ & $0,14(2)$ & $0,44(25)$ \\
\hline
\end{tabular}

Tabela 4.9: Valores médios das áreas das bandas de absorção, relacionadas aos modos vibracionais dos lipídeos das diversas linhagens de células neoplásicas, juntamente com os valores obtidos para as células sadias PBMC.Os valores apresentados na coluna referente aos picos de absorção, são valores correspondentes à região aproximada a qual as bandas de absorção estão localizadas no espectro.

Embora comparada com linhagens tumorais obtidas a partir de diversas doenças, as células PBMC apresentaram valores referentes às áreas inferiores em todas as bandas de absorção referentes à região dos lipídeos. 
Este fato pode ser atribuído à hiperexpressão da enzima FAS ("fatty acid synthase"), no caso das células tumorais; esta enzima é responsável pela síntese de ácidos graxos. A hiperexpressão desta enzima está associada a células com alto potencial de proliferação, ou seja, células neoplásicas.

Em tecidos normais, os níveis de expressão da enzima FAS são relativamente baixos, uma vez que os ácidos graxos necessários para a manutenção das atividades celulares normais, são supridos através da própria dieta. A hiperexpressão da enzima FAS em tumores sugere que os mesmos necessitam de uma quantidade de ácidos graxos superior àquela obtida através da dieta.

Desta forma, podemos supor que o aumento das áreas das bandas de absorção relacionadas aos lipídeos observado em células tumorais podem ser associadas à hiperexpressão da enzima FAS, embora muitos outros efeitos estejam ocorrendo; os valores médios apresentados para as diversas linhagens neoplásicas são compatíveis entre si, ao passo que em células sadias (PBMC), tais os valores são menores, sendo portanto condizentes com a suposição apresentada.

\subsection{Estrutura secundária das proteínas: análise das bandas de absorção referentes às amidas}

Conforme descrito na seção 4, o espectro de absorção das linhagens celulares estudadas possuem uma região que pode ser associada às proteínas; na região compreendida entre $1300-1660 \mathrm{~cm}^{-1}$, podemos observar as bandas de absorção referentes à amida I, amida II e amida III. De acordo com a literatura, as posições das bandas referentes à amida I e amida II são indicativas da estrutura das proteínas [2, 46, 48, 49].

A banda de absorção localizada na região próxima à $1309 \mathrm{~cm}^{-1}$ é atribuída à amida III, e a banda centrada próxima à $1540 \mathrm{~cm}^{-1}$, corresponde ao modo de estiramento da molécula de amida II $[41,2]$.

Na região compreendida entre $1640-1655 \mathrm{~cm}^{-1}$, as bandas de absorção são associadas à amida I; a banda situada em cerca de $1646 \mathrm{~cm}^{-1}$ está relacionada à configuração beta, ao passo que a banda situada em cerca de $1652 \mathrm{~cm}^{-1}$ está relacionada à estrutura alfa hélice das proteínas [46, 2]; desta forma a banda de absorção da amida I pode ser utilizada como um indicador da conformação das proteínas [49, 48].

As bandas de absorção referentes às amidas são derivadas dos modos vibracionais de estiramento das moléculas de $\mathrm{C}=\mathrm{O}[49,48]$, acoplado em fase com o modo de flexão das ligações $\mathrm{N}-\mathrm{H}$ e estiramento das moléculas de $\mathrm{N}-\mathrm{C}$, originando bandas situadas na região entre $1600 \mathrm{~cm}^{-1}$ e $1700 \mathrm{~cm}^{-1}$.

Os principais fatores responsáveis pela sensibilidade conformacional das amidas incluem as ligações do tipo ponte de hidrogênio e o acoplamento entre os dipolos de 
transições $[49,48]$. O acoplamento entre os dipolos de transições, leva à ocorrência de uma divisão dos modos vibracionais da amida I. A magnitude desta divisão depende da orientação e da distância entre os dipolos, fornecendo portanto, informações geométricas com relação aos arranjos dos grupos de peptídios das moléculas de amida.

A relação entre a posição da banda de absorção da amida I e o tipo de estrutura secundária pode ser melhor definida através da análise espectral, a qual foi primeiramente demonstrada por Elliot e Ambrose (1950) [90], que mostraram a existência de uma correlação empírica entre a freqüência de absorção das então denominadas amida I e amida II. Estes estudos demonstraram que as proteínas, que eram conhecidas por serem predominantementes compostas de estruturas helicoidais, exibiram bandas de absorção na região espectral de $1652 \mathrm{~cm}^{-1}$ a $1657 \mathrm{~cm}^{-1}$ e $1545 \mathrm{~cm}^{-1}$ a $1551 \mathrm{~cm}^{-1}$, respectivamente, em solução aquosa, ao passo que proteínas compostas predominantemente pela conformação beta, exibiram bandas de absorção semelhantes, porém, na região entre $1628 \mathrm{~cm}^{-1}$ a $1635 \mathrm{~cm}^{-1}$ e $1521 \mathrm{~cm}^{-1}$ a $1525 \mathrm{~cm}^{-1}[90]$.

A caracterização da estrutura protéica, através da banda de absorção referente à amida III apresenta problemas, uma vez que a natureza exata da informação obtida e sua relação com a estrutura secundária das proteínas não é totalmente entendida [90]; além disso, na regiao a qual esta situada esta banda de absorção da amida III, e uma região espectral associada a outros modos vibracionais, como por exemplo, as vibrações do tipo abano das moléculas de $\mathrm{CH}_{2}$.

A determinação exata da banda de absorção referente à amida III, é difícil de se realizar, porém geralmente esta é encontrada em uma freqüência de absorção situada cerca de 50 a $70 \mathrm{~cm}^{-1}$ além da região referente ao componente principal da configuração beta $[91]$.

Através da espectroscopia por FTIR, é possível determinar espectros de proteínas tanto em soluções, quanto no desidratadas. No entanto, o grau de hidratação das proteínas é um fator importante a ser considerado ao analisá-las. Por exemplo, para a plena atividade biológica da maior parte das proteínas, um nível de hidratação de cerca de $40 \%$ faz-se necessário [32, 90].

Na figura 4.17 são apresentadas as derivadas de segunda ordem dos espectros de absorção, referentes a cada uma das linhagens celulares estudadas. Tais espectros estão agrupados dois a dois, de acordo com o tipo de neoplasia, sendo enfatizada a região referente às bandas de absorção das amidas. 


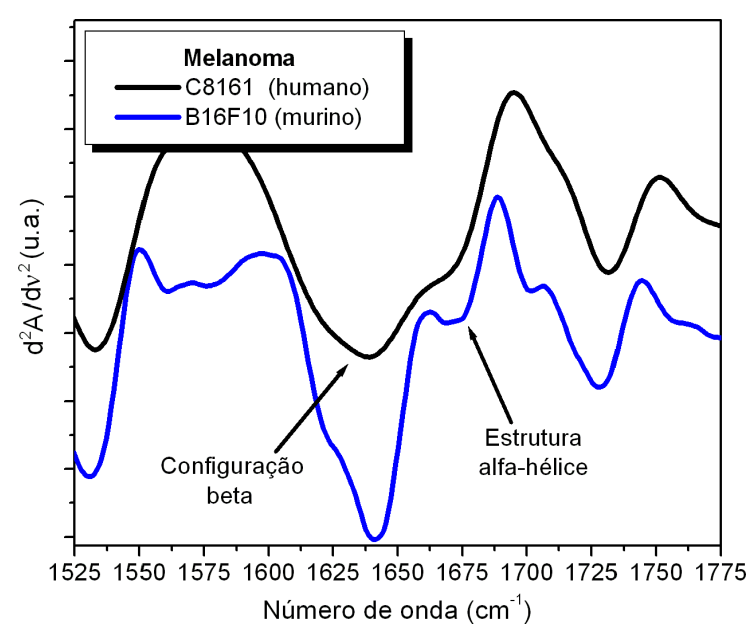

(a) Melanoma humano e murino

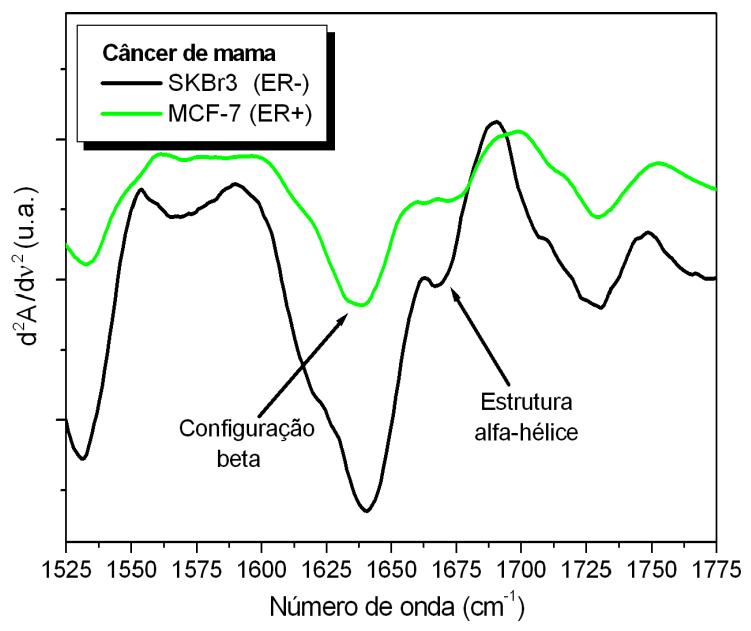

(c) Câncer de mama com ER+ e ER-

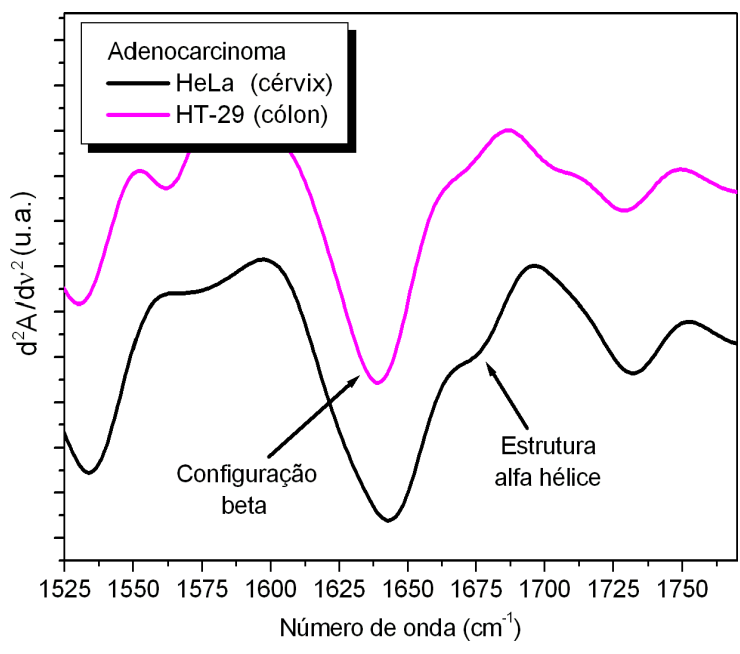

(b) Adenocarcinoma de cérvix e de cólon

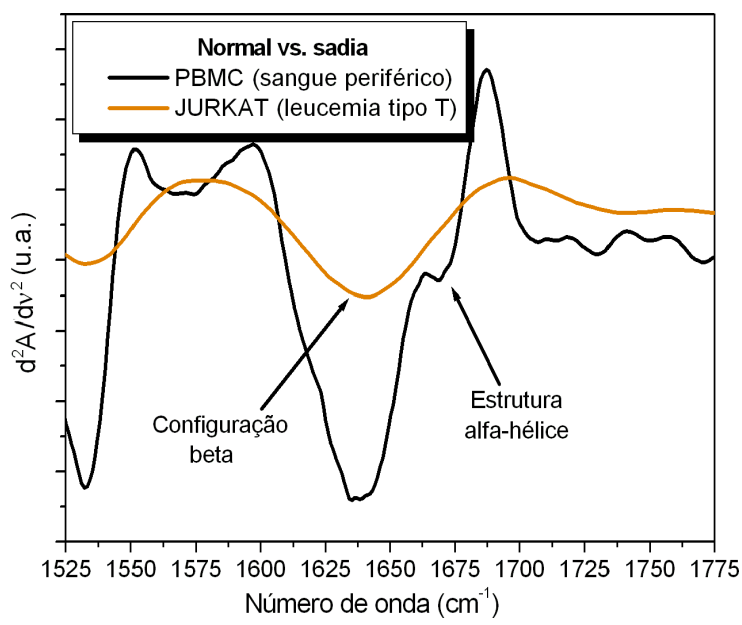

(d) Leucemia tipo $\mathrm{T}$ e células periféricas monucleares humanas

Figura 4.17: Derivada de segunda ordem da região do espectro de absorção referente à amida I, uma vez que esta molécula é sensível à conformação das proteínas celulares. As bandas localizadas em $1646 \mathrm{~cm}^{-1}$ e $1652 \mathrm{~cm}^{-1}$ estão associadas à conjugação beta e estrutura alfa-hélice, respectivamente.

Na tabela 4.10 são apresentados os valores referentes às áreas das bandas de absorção, referentes à configuração beta e estrutra alfa hélice das proteínas celulares. O valor dos picos de absorção, obtidos através da segunda derivada do espectro de absorção também são apresentados. 


\begin{tabular}{|c|c|c|c|c|}
\hline \multirow{2}{*}{ Linhagem } & \multicolumn{2}{|c|}{ Estrutura alfa-hélice } & \multicolumn{2}{c|}{ Configuração beta } \\
\cline { 2 - 5 } & Áreas & Pico $\left(\mathrm{cm}^{-1}\right)$ & Áreas & Pico $\left(\mathrm{cm}^{-1}\right)$ \\
\hline \hline C8161 & $1,25(22)$ & $1652,60(51)$ & $5,11(91)$ & $1643,00(17)$ \\
\hline B16F10 & $2,77(14)$ & $1653,20(38)$ & $5,57(20)$ & $1641,20(29)$ \\
\hline HT-29 & $2,69(20)$ & $1653,10(60)$ & $7,46(54)$ & $1641,80(90)$ \\
\hline HeLa & $2,47(24)$ & $1650,70(19)$ & $8,71(21)$ & $1646,20(11)$ \\
\hline SKBr3 & $4,15(55)$ & $1651,80(83)$ & $10,99(86)$ & $1641,30(18)$ \\
\hline MCF-7 & $2,21(28)$ & $1650,00(63)$ & $14,13(85)$ & $1643,80(98)$ \\
\hline JURKAT & $2,89(15)$ & $1651,80(20)$ & $10,81(57)$ & $1642,60(90)$ \\
\hline PBMC & $0,99(05)$ & $1652,20(18)$ & $16,69(83)$ & $1644,30(67)$ \\
\hline
\end{tabular}

Tabela 4.10: Valores médios das áreas e picos das bandas de absorção da região da amida I, referentes às linhagens celulares: C8161, melanoma humano; B16F10, melanoma murino; HT-29, adenocarcinoma de cólon. HeLa, adenocarcinoma de cérvix; SKBr3, câncer de mama (ER-);MCF-7, câncer de mama (ER+); JURKAT, leucemia do tipo T e PBMC, células mononucleares de sangue periférico humano.

Observando-se os valores apresentados, é importante destacar os resultados obtidos para a linhagem de células normais (PBMC) com relação as demais linhagens (neoplásicas). No caso das células PBMC notamos uma baixa ocorrência de proteínas com estrutura alfa-hélice, ao passo que no caso da configuração beta, o valor obtido para as células consideradas normais foi o mais elevado. A linhagem PBMC apresentou uma diferença de cerca de 15, 70 quando comparamos a ocorrência da estrutura alfa-hélice com a configuração beta, ao passo que esta diferença, no caso das linhagens tumorais, foi de no máximo 11, 92 (no caso da linhagem MCF-7).

Um dos problemas, relacionados com a utilização da região referente à banda da amida I para a análise de proteínas secas, é o surgimento de "novas" bandas, as quais são muitas vezes atribuídas à configuração beta intermolecular; nas regiões referentes às amidas II e III, o aparecimento de tais bandas não são verificadas.

As amidas II e III aparecem em regiões menos suscetíveis aos efeitos ambientais, no entanto, apenas a região amida I contém uma banda típica de agregação não covalente [50]; porém devido à sobreposição de diversos elementos estruturais na região da amida II e, conforme discutido anteriormente, devido a dificuldade de se definir a posição da banda da amida III, a utilização de ambas as regiões para a determinação quantitativa destes compostos e eventual normalização dos espectros de absorção não são ideais.

Desta forma, supomos que a banda referente a amida I, embora seja largamente 
utilizada como referência na normalização espectral, também não se trata de uma banda estável o suficiente para tal fim; devido à este fato, a normalização dos espectros foi realizada utilizando-se a banda de absorção relativa às moleculas de $\mathrm{PO}_{2}$, conforme discutido na seção 3.3. Supomos ainda que as alterações observadas nesta região devemse à perda das estruturas quaternárias, terciárias ou secundárias que ocorrem devido à ação de qualquer fator capaz de alterar as ligações químicas que mantêm tais estruturas (como por exemplo, a secagem das células). Na desnaturação protéica não há perda da estrutura primária, ou seja, a seqüência dos aminoácidos é mantida.

\subsection{Análise de razões}

De acordo com os resultados e discussões apresentadas nas seções 4, 4.1, 4.2, 4.3, 4.4 e 4.5 ficou claro que o objetivo de caracterizar as diversas linhagens celulares estudadas foi atingido.

Embora nosso foco tenha sido a caracterização de diversas linhagens celulares através da espectroscopia por FTIR, nesta seção são apresentados os resultados referentes à uma breve análise de razões entre as áreas das diversas bandas de absorção; através da análise das razões foi possível diferenciar as linhagens celulares estudadas.

Diversos autores adotam a análise das razões entre as bandas de absorção como uma forma de obter índices capazes de diferenciar linhagens celulares ou tecidos biológicos $[47,7,4,89]$. As razões mais comumente adotadas envolvem as bandas de absorção relacionadas ao DNA, RNA e amidas.

De acordo com a revisão bibliográfica realizada, foram definidas as quatro razões mais utilizadas em diversos trabalhos de diferenciação celular; todas as razões têm em comum o fato de utilizarem a banda de absorção referente à amida I como denominador. A primeira razão relacionada a banda de absorção da amida I (região próxima à $1650 \mathrm{~cm}^{-1}$ ) com a banda centrada próxima à $1540 \mathrm{~cm}^{-1}$, associada à amida II. A segunda razão, relaciona a banda da amida I com a banda associada às ligações fosfodiéster presentes em abundância na molécula de DNA, a qual está situada na região próxima à $1084 \mathrm{~cm}^{-1}$. A terceira razão relaciona a banda da amida I com a banda de absorção situada próxima à $1740 \mathrm{~cm}^{-1}$, associada ao modo vibracional da ligação $\mathrm{C}=\mathrm{O}$, presente nos lipídeos. Por fim, é comum o estudo da razão entre as bandas de absorção situadas próximas à $1084 \mathrm{~cm}^{-1}$ e $1120 \mathrm{~cm}^{-1}$, as quais estão associadas às moléculas de DNA e RNA.

A adoção de tais bandas como referência para a obtenção de índices capazes de diferenciar amostras biológicas é interessante, uma vez que estão associadas bandas referentes ao DNA, RNA, proteínas e lipídeos, as quais são as principais macromoléculas componentes das células e tecidos.

Na figura 4.18 são apresentadas as razões acima citadas, calculadas para cada uma ds linhagens celulares apresentadas neste trabalho. Na figura 4.18(a) são apresentados os 
valores referentes à razão entre as bandas de absorção situadas na região de $1650 \mathrm{~cm}^{-1} \mathrm{e}$ $1540 \mathrm{~cm}^{-1}$; na figura 4.18 (b), são apresentadas as razões relacioandas às bandas $1650 \mathrm{~cm}^{-1}$ e $1740 \mathrm{~cm}^{-1}$; na figura 4.18 (c) e 4.18 (d) temos as razões referentes às bandas $1650 \mathrm{~cm}^{-1}$ e $1084 \mathrm{~cm}^{-1}, 1120 \mathrm{~cm}^{-1}$ e $1084 \mathrm{~cm}^{-1}$, respectivamente.

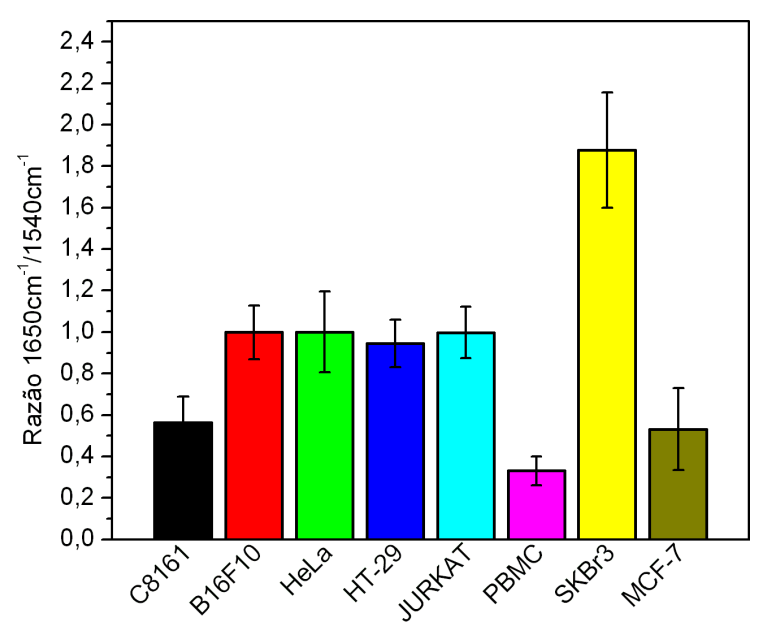

(a) Razão entre as bandas de absorção associadas à amida I e à amida II, duas moléculas componentes das proteínas

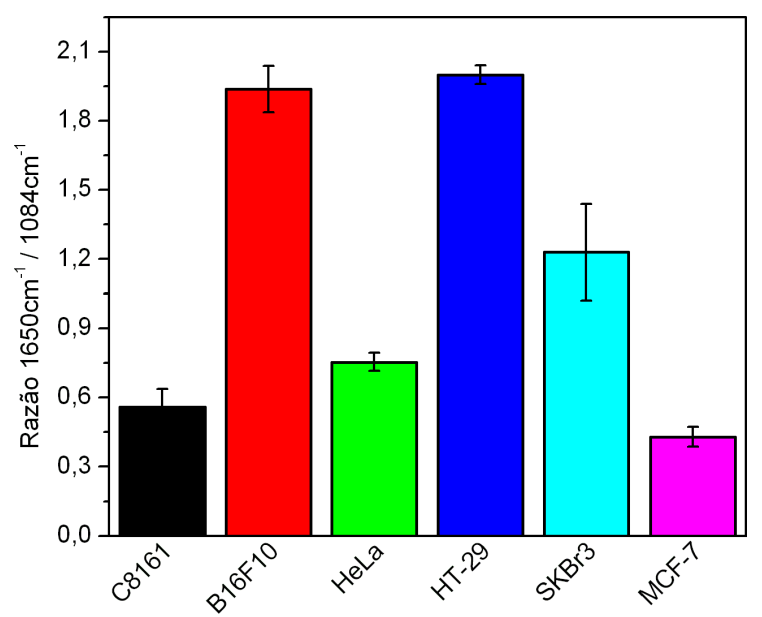

(c) Razão entre as bandas de absorção associadas à amida I (proteínas) e ao DNA

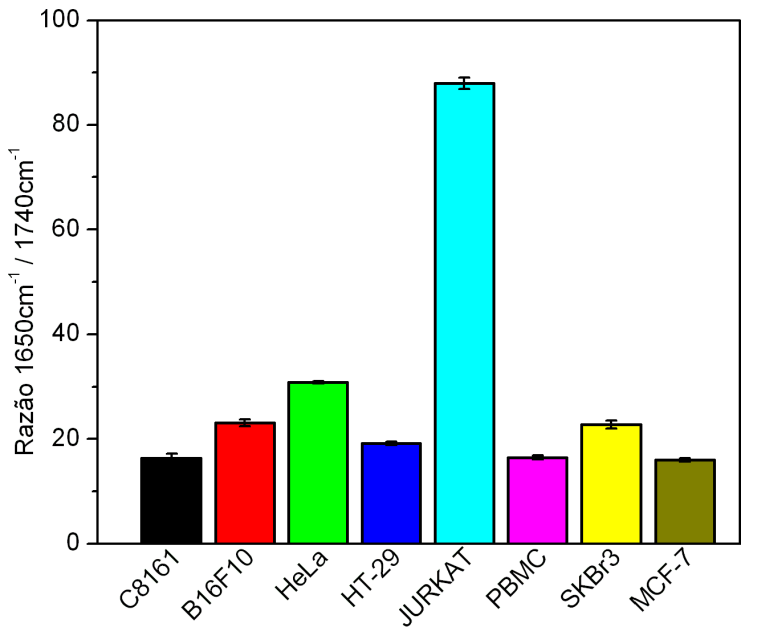

(b) Razão entre as bandas de absorção associadas à amida $\mathrm{I}$ (proteínas) e aos lipídeos

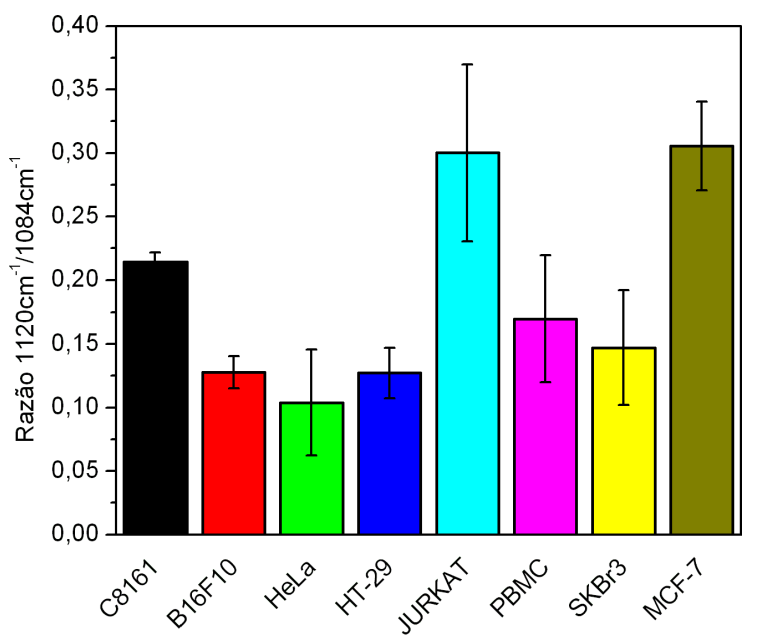

(d) Razão entre as bandas de absorção associadas ao DNA e ao RNA

Figura 4.18: Valores médios das razões comumente adotadas na literatura, calculadas para cada linhagem celular estudada neste trabalho. Tais razões relacionam as principais macromoléculas presentes nas amostras biológicas: as proteínas, lipídeos, DNA e RNA.

Observando-se os resultados obtidos através destas combinações de bandas de absorção, notamos que razões relacionadas às bandas $1650 \mathrm{~cm}^{-1}, 1740 \mathrm{~cm}^{-1}$ e $1650 \mathrm{~cm}^{-1}$, $1084 \mathrm{~cm}^{-1}$ (figuras 4.18 (b) e $4.18(\mathrm{c})$ ) são capazes de diferenciar as linhagens celulares dentro de uma mesma doença, ou seja, é possível diferenciar o melanoma murino e o me- 
lanoma humano, assim como o adenocarcinoma de cérvix e o adenocarcinoma de cólon, por exemplo.

O mesmo não ocorre com as razões obtidas através das bandas $1650 \mathrm{~cm}^{-1}, 1540 \mathrm{~cm}^{-1}$ e $1120 \mathrm{~cm}^{-1}, 1084 \mathrm{~cm}^{-1}$ (figuras 4.18(a) e 4.18(d)); nestas últimas notamos que há uma subreposição de valores para diversas linhagens.

Uma vez que as principais razões adotadas na literatura não são capazes de diferenciar um conjunto maior de amostras, apresentando falhas inclusive em comparações entre apenas dois elementos, foram buscadas combinações de bandas de absorção alternativas àquelas utilizadas na literatura, as quais seriam mais eficientes na diferenciação de amostras biológicas dentro de um mesmo grupo patológico, e ainda quando comparadas com outros tipos de doenças.

Após a realização de diversos testes, combinando-se as principais bandas de absorção características das amostras biológicas (amidas, lipídeos, DNA e RNA), foram obtidos pares de bandas de absorção os quais foram capazes de diferenciar as oito linhagens celulares apresentadas ao longo deste trabalho.

As combinações que satisfizeram a condição de diferenciar todas as linhagens foram:(i) $1053 \mathrm{~cm}^{-1}$ e $1084 \mathrm{~cm}^{-1}$; (ii) $1540 \mathrm{~cm}^{-1}$ e $10840 \mathrm{~cm}^{-1}$; (iii) $1650 \mathrm{~cm}^{-1}$ e $1084 \mathrm{~cm}^{-1}$; (iv) $1395 \mathrm{~cm}^{-1}$ e $1053 \mathrm{~cm}^{-1}$; (v) $1453 \mathrm{~cm}^{-1}$ e $1053 \mathrm{~cm}^{-1}$; (vi) $1084 \mathrm{~cm}^{-1}$ e $1646 \mathrm{~cm}^{-1}$; (vii) $1084 \mathrm{~cm}^{-1}$ e $2851 \mathrm{~cm}^{-1}$ e, por fim, (viii) $1053 \mathrm{~cm}^{-1}$ e $3060 \mathrm{~cm}^{-1}$.

Na figura 4.19 são apresentados os valores médios das razões obtidas para cada uma das linhagens celulares, assim como sua respectiva incerteza. De acordo com os gráficos apresentados é possível notar que para todas as combinações apresentadas, foi possível diferenciar as oito linhagens e não somente de acordo com o tipo de patologia, conforme as razões adotadas na literatura.

Em alguns casos, é possível notar diferenças mais acentuadas entre as oito linhagens, porém para todas as combinações apresentadas, os valores médios das razões de cada linhagem são considerados estatisticamente distintos, de acordo com o teste t de Student, cujo intervalo de rejeição considerado foram os valores de $p$ superiores à 0,05 .

Nas tabelas 4.11, 4.12, 4.13 e 4.14 são apresentados os valores de $p$, ao compararmos cada um dos possíveis agrupamentos das linhagens celulares (duas a duas), para cada uma das razões entre bandas de absorção apresentadas na figura 4.19. 


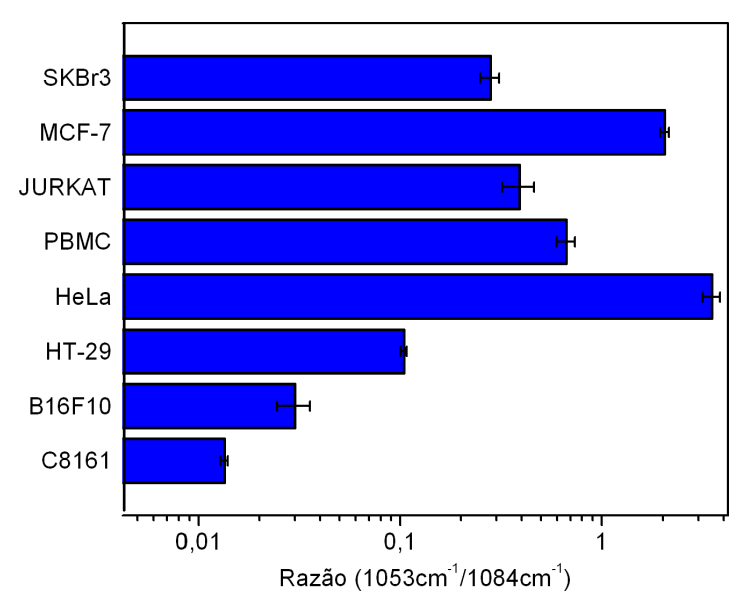

(a) Razão entre as bandas de absorção associadas com os carboidratos $\left(1053 \mathrm{~cm}^{-1}\right)$ e as ligações fosfodiésteres do DNA $\left(1084 \mathrm{~cm}^{-1}\right)$.

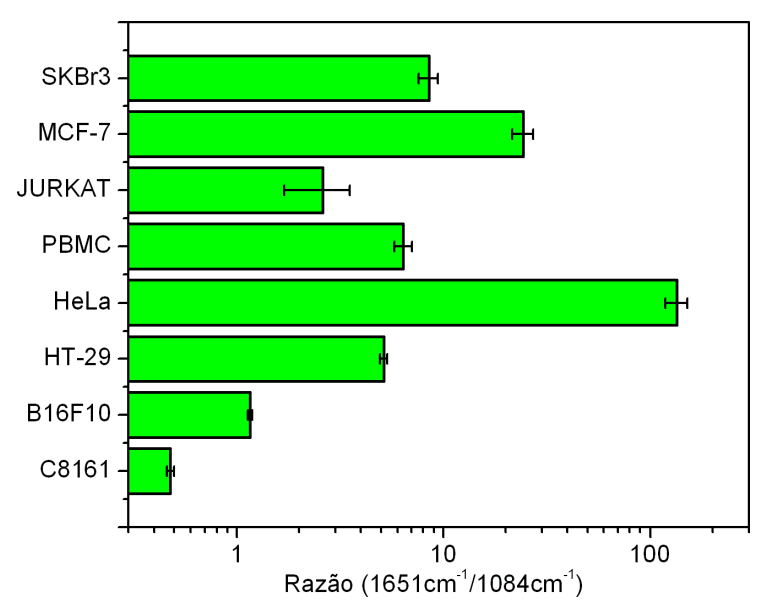

(c) Razão entre as bandas de absorção associadas com a molécula de amida I $\left(1651 \mathrm{~cm}^{-1}\right)$ e as ligações fosfodiésteres do DNA $\left(1084 \mathrm{~cm}^{-1}\right)$.

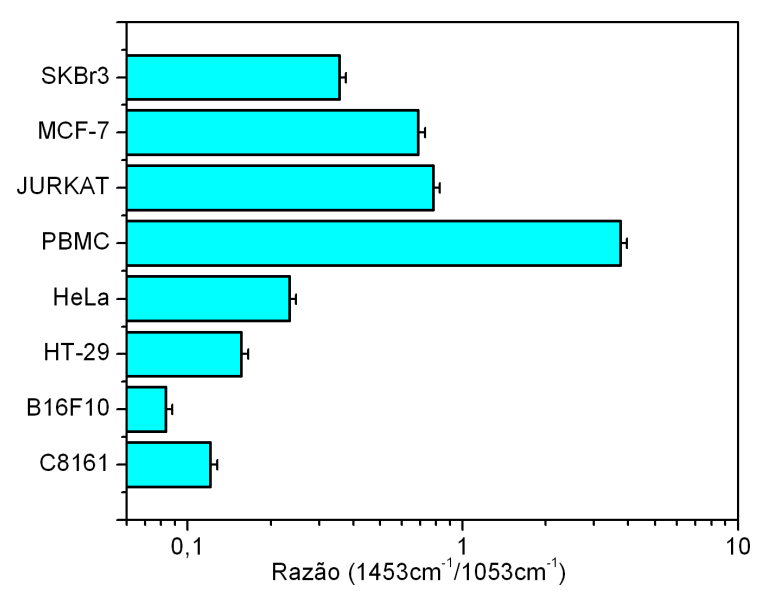

(e) Razão entre as bandas de absorção associadas com as proteínas e lipídeos $\left(1453 \mathrm{~cm}^{-1}\right)$ e os carboidratos $\left(1053 \mathrm{~cm}^{-1}\right)$.

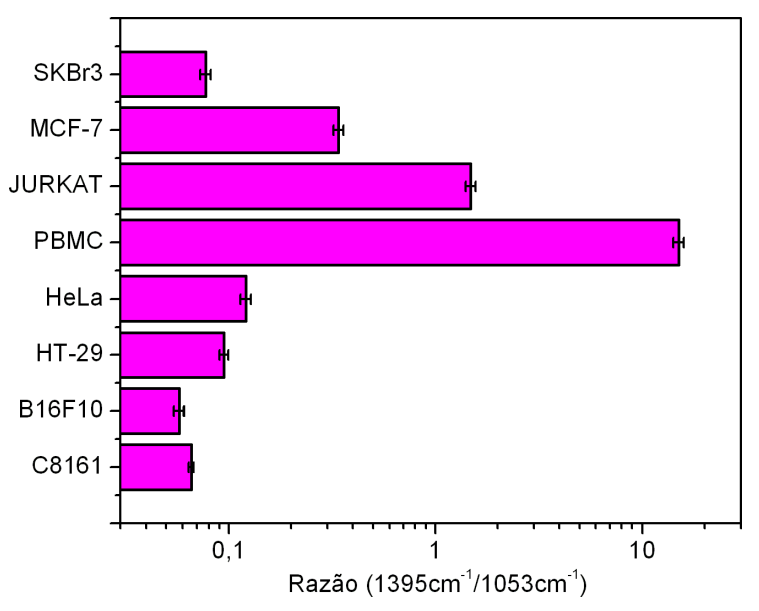

(b) Razão entre as bandas de absorção associadas com as proteínas e lipídeos $\left(1395 \mathrm{~cm}^{-1}\right)$ e os carboidratos $\left(1053 \mathrm{~cm}^{-1}\right)$.

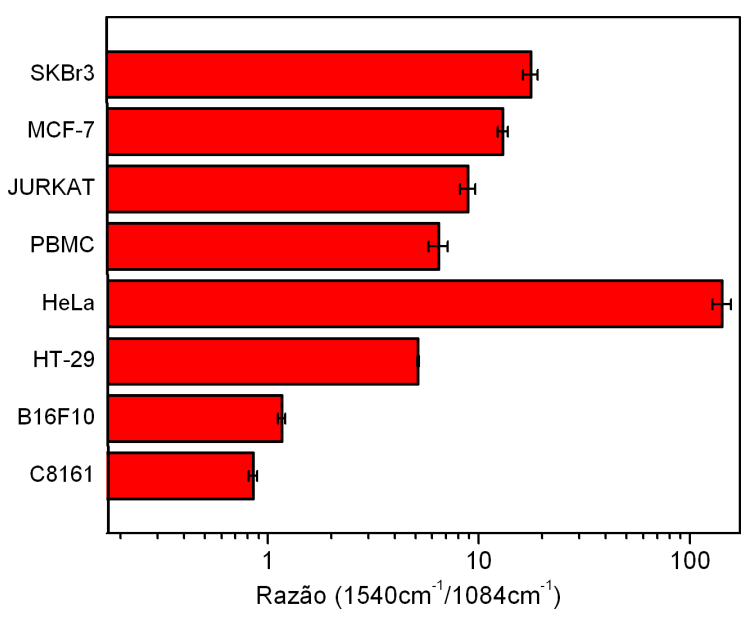

(d) Razão entre as bandas de absorção associadas com a amida II $\left(1540 \mathrm{~cm}^{-1}\right)$ e as ligações fosfodiésteres do DNA $\left(1084 \mathrm{~cm}^{-1}\right)$.

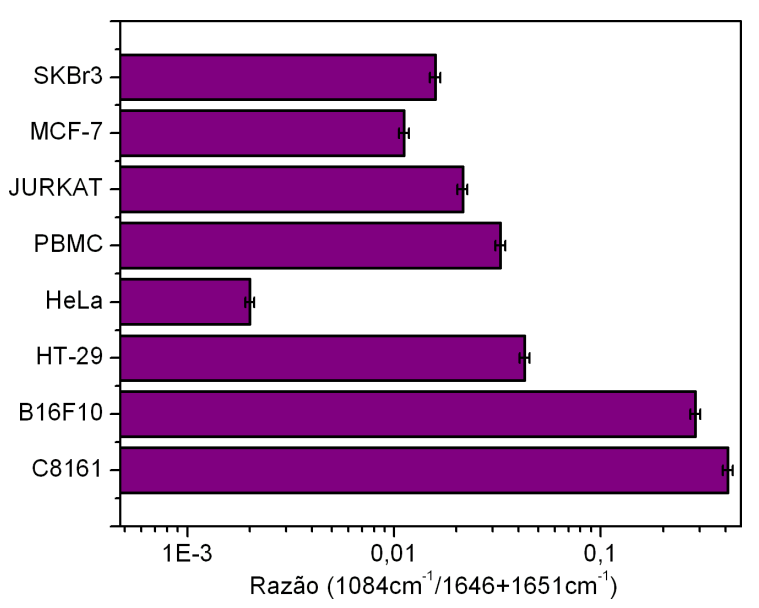

(f) Razão entre as bandas de absorção associadas com as ligações fosfodiésteres do DNA $\left(1084 \mathrm{~cm}^{-1}\right)$ e a molécula de amida I (1646 e $\left.1651 \mathrm{~cm}^{-1}\right)$. 


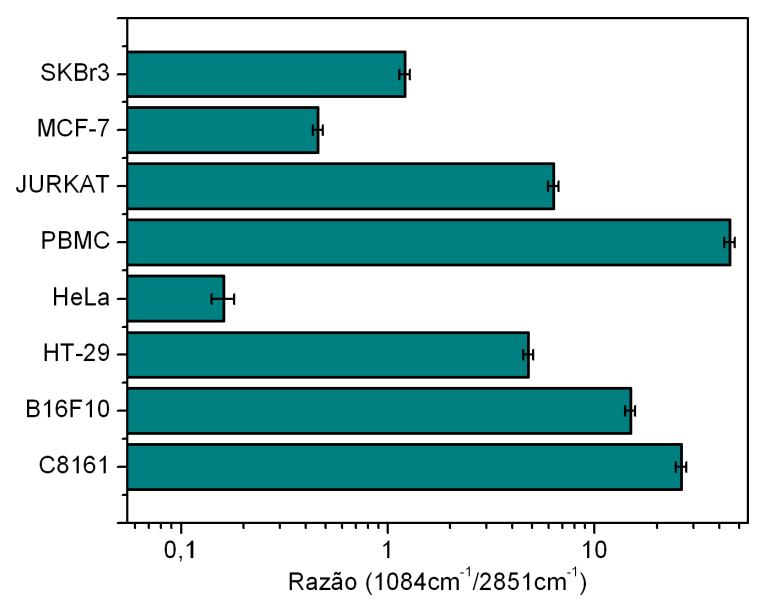

(g) Razão entre as bandas de absorção associadas com as ligações fosfodiésteres do DNA $\left(1084 \mathrm{~cm}^{-1}\right)$ e ácidos graxos $\left(2851 \mathrm{~cm}^{-1}\right)$.

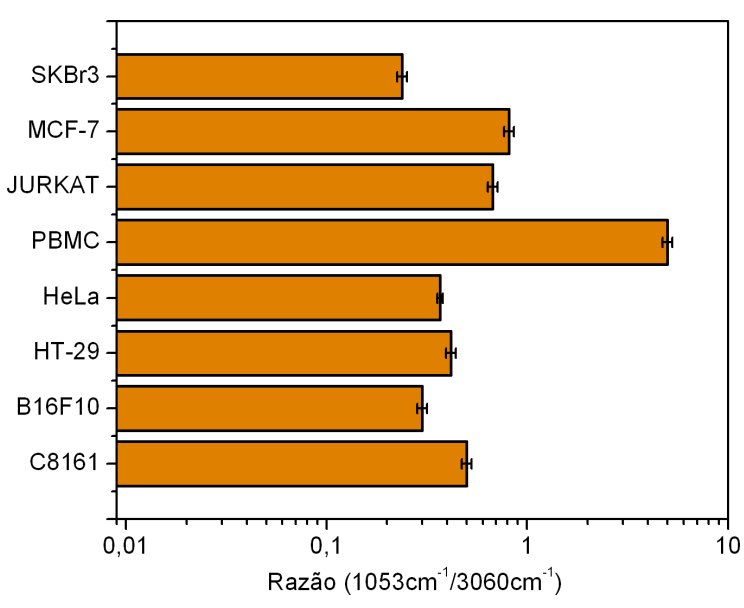

(h) Razão entre as bandas de absorção associadas com os carboidratos $\left(1053 \mathrm{~cm}^{-1}\right)$ e lipídeos $\left(3060 \mathrm{~cm}^{-1}\right)$.

Figura 4.19: Valores médios das razões definidas com o objetivo de diferenciar todas as linhagens celulares estudadas neste trabalho. Tais razões relacionam as principais macromoléculas presentes nas amostras biológicas: as proteínas, lipídeos e DNA.

De acordo com os valores apresentados nas tabelas 4.11, 4.12, 4.13 e 4.14, é possível verificar que as razões adotadas atendem satisfatoriamente a condição de diferenciação celular independente do tipo da patologia, sendo portanto, mais eficiente quando comparada com as razões largamente adotadas na literatura.

Desta forma, com a definição de razões as quais possivelmente podem ser empregadas de maneira geral para diversas amostras biológicas, a apresentação dos resultados referentes as etapas de caracterização e diferenciação das linhagens celulares é concluída. 


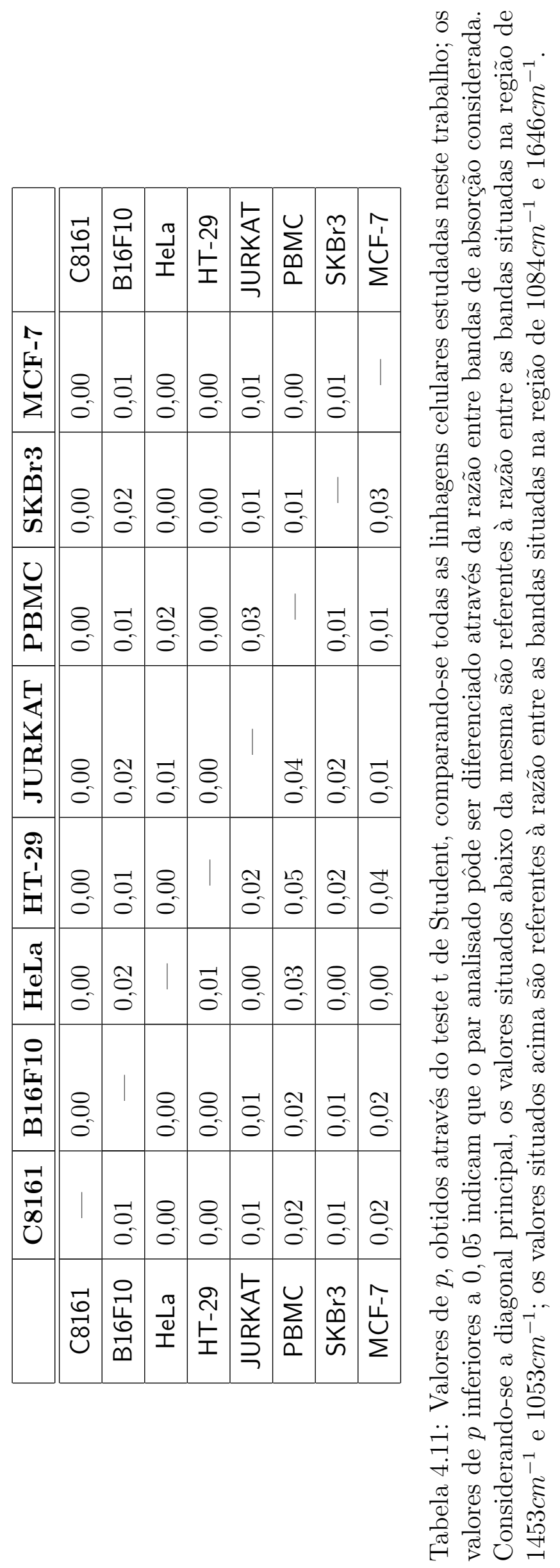




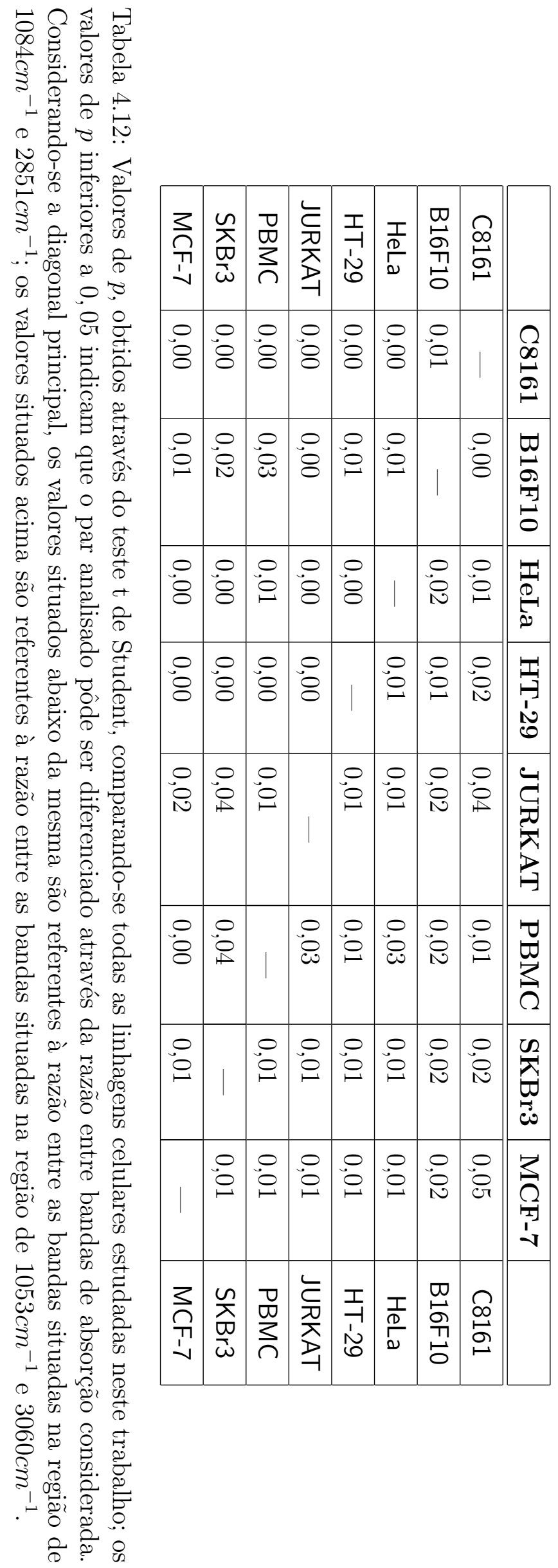


है बृं ช

实

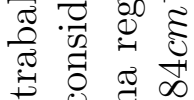

0 is

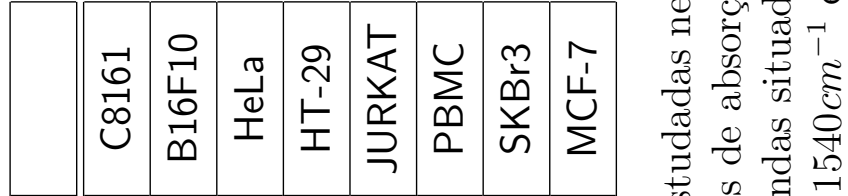

$\underset{\exists}{ } D_{0}$

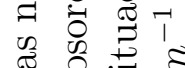

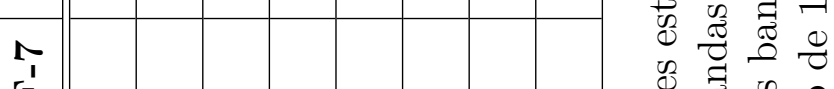

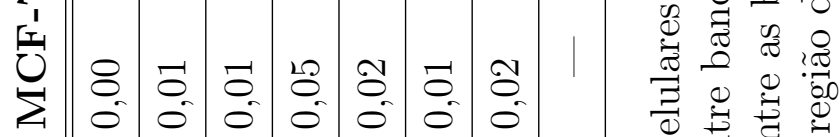

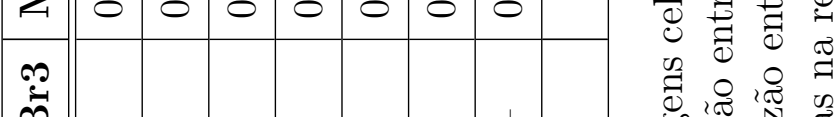

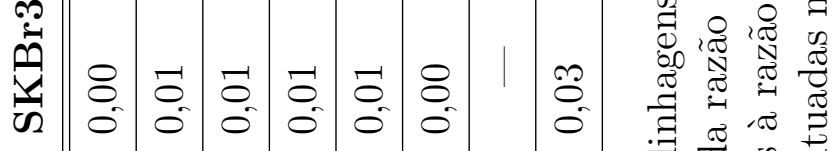

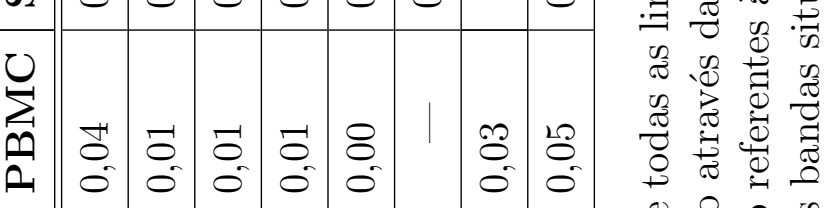

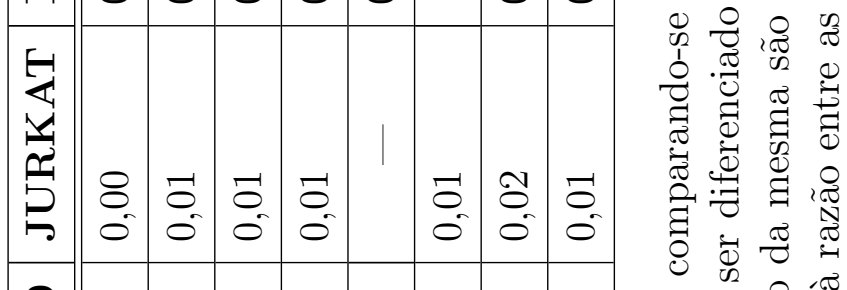

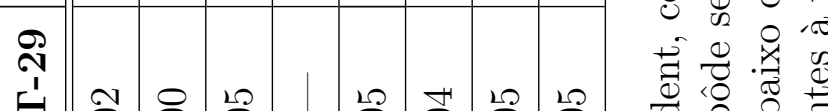

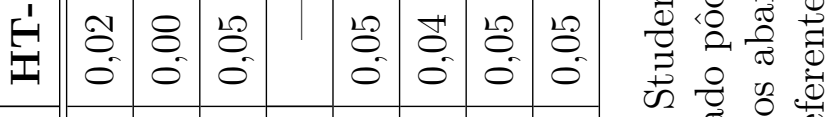

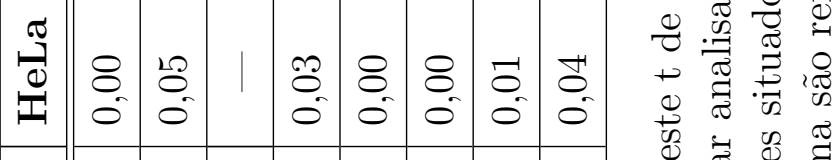

ర్లై

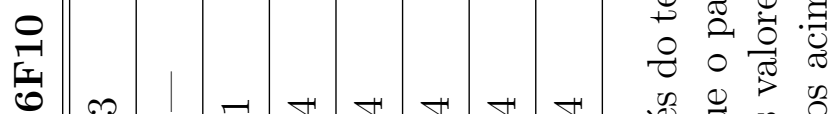

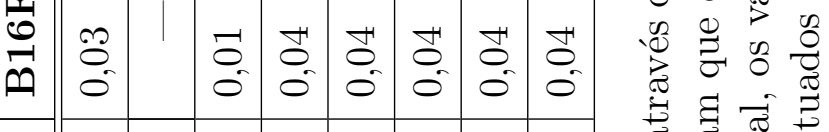

\begin{tabular}{|c|c|c|c|c|c|c|c|}
\hline & $\begin{array}{l}12 \\
0 \\
0\end{array}$ & $\begin{array}{l}8 \\
0\end{array}$ & $\begin{array}{l}\mathscr{O} \\
0 \\
0\end{array}$ & $\begin{array}{l}8 \\
0\end{array}$ & $\begin{array}{l}8 \\
0 \\
0\end{array}$ & $\begin{array}{l}5 \\
8\end{array}$ & $\begin{array}{l}5 \\
0 \\
0\end{array}$ \\
\hline $\begin{array}{l}\vec{b} \\
\overrightarrow{1} \\
0\end{array}$ & $\begin{array}{l}0 \\
\overrightarrow{1} \\
\underline{\omega} \\
-\overrightarrow{0} \\
\end{array}$ & 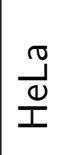 & $\begin{array}{l}\text { શ } \\
\stackrel{1}{I} \\
\text { 足 }\end{array}$ & 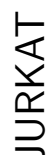 & $\sum_{\substack{U \\
\Delta}}^{\cup}$ & $\begin{array}{l}\frac{m}{n} \\
\frac{y}{\omega}\end{array}$ & $\begin{array}{l}\stackrel{\sim}{\iota^{\prime}} \\
\stackrel{U}{\Sigma}\end{array}$ \\
\hline
\end{tabular}

ช

.

0 응

र० $\overbrace{0}^{\circ}$ क

$8 \approx 80$

Ðै

西.

$\ddot{2}$ 记

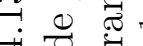

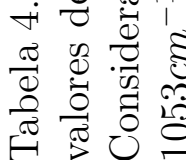




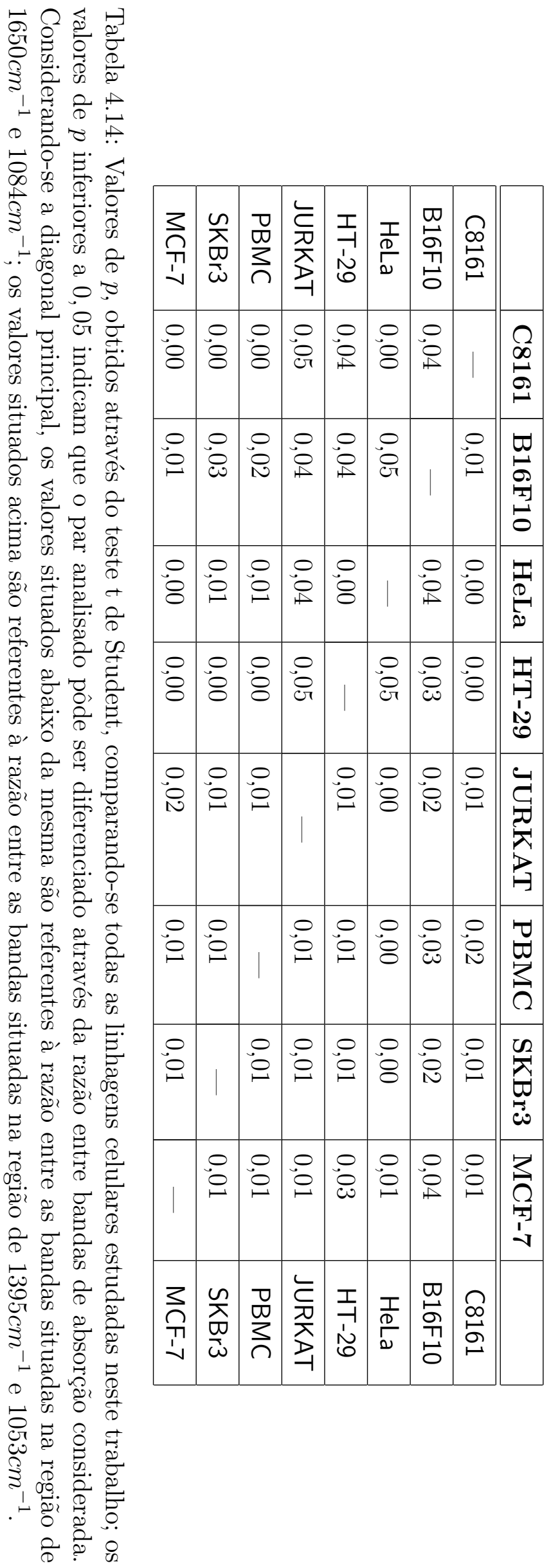




\section{Capítulo 5}

\section{Conclusões}

Diversas linhagens celulares foram caracterizadas através da espectroscopia por FTIR; foram estudadas oito linhagens, as quais foram agrupadas duas a duas, de acordo com o tipo de doença: melanoma murino e humano, adenocarcinoma de cérvix e cólon, duas linhagens de câncer de mama (diferindo apenas bioquimicamente) e um último grupo, contendo uma linhagem de leucemia humana e células normais (linfócitos T).

Através deste trabalho foi possível verificar o potencial de aplicação da espectroscopia por FTIR em estudos de base, visando a caracterização de células do ponto de vista bioquímico, buscando compreender quais fatores biológicos estão relacionados com as diferenças espectrais verificadas e, com isso, fornecer informações qualitativas referentes à ligações químicas relacionadas a determinados biomarcadores existentes em cada amostra biológica.

Analisando-se as áreas referentes a cada banda de absorção identificada, foi possível estudar a variação da quantidade de certas macromoléculas existentes nas células; foram estabelecidas hipóteses baseadas nas diferenças encontradas com relação às moléculas de DNA, RNA, proteínas e lipídeos.

No caso das linhagens referentes aos melanomas, foram observados deslocamentos dos picos nas regiões próximas à $1085 \mathrm{~cm}^{-1}, 1395 \mathrm{~cm}^{-1}$ e $1739 \mathrm{~cm}^{-1}$. Alterações com relação às áreas da bandas de absorção foram observadas nas regiões de cerca de $1122 \mathrm{~cm}^{-1}$, $1169 \mathrm{~cm}^{-1}, 1308 \mathrm{~cm}^{-1}, 1543 \mathrm{~cm}^{-1}, 1646 \mathrm{~cm}^{-1}, 1652 \mathrm{~cm}^{-1}, 2851 \mathrm{~cm}^{-1}, 2922 \mathrm{~cm}^{-1}, 3062 \mathrm{~cm}^{-1}$ e $3184 \mathrm{~cm}^{-1}$.

O conjunto das linhagens celulares composto por adenocarcinomas apresentou diferenças na posição das bandas de absorção nas regiões próximas à $1084 \mathrm{~cm}^{-1}, 1158 \mathrm{~cm}^{-1}, 1453 \mathrm{~cm}^{-1}$ e $3060 \mathrm{~cm}^{-1}$. Com relação às áreas das bandas de absorção, as diferenças foram verificadas em cerca de $918 \mathrm{~cm}^{-1}, 967 \mathrm{~cm}^{-1}, 1084 \mathrm{~cm}^{-1}, 1158 \mathrm{~cm}^{-1}, 1308 \mathrm{~cm}^{-1}, 1646 \mathrm{~cm}^{-1}, 1650 \mathrm{~cm}^{-1}$, $1742 \mathrm{~cm}^{-1}, 2852 \mathrm{~cm}^{-1}$ e $3060 \mathrm{~cm}^{-1}$.

Os cânceres de mama apresentaram deslocamentos dos picos em cerca de $1122 \mathrm{~cm}^{-1}$, $1397 \mathrm{~cm}^{-1}, 1651 \mathrm{~cm}^{-1}, 2851 \mathrm{~cm}^{-1}$ e $2962 \mathrm{~cm}^{-1}$; ao passo que apresentaram diferenças com 
relação às áreas das bandas de absorção nas regiões situadas em cerca de $1039 \mathrm{~cm}^{-1}$, $1087 \mathrm{~cm}^{-1}, 1397 \mathrm{~cm}^{-1}, 1543 \mathrm{~cm}^{-1}, 1651 \mathrm{~cm}^{-1}$ e $2924 \mathrm{~cm}^{-1}$.

Por fim, as linhagens de leucemia tipo $\mathrm{T}$ e linfócitos $\mathrm{T}$ apresentaram deslocamentos dos picos nas regiões próximas à $1043 \mathrm{~cm}^{-1}, 1397 \mathrm{~cm}^{-1} .1651 \mathrm{~cm}^{-1}, 1745 \mathrm{~cm}^{-1}$ e $2851 \mathrm{~cm}^{-1}$. Diferenças relacionadas com as áreas das bandas de absorção foram verificadas em cerca de $1043 \mathrm{~cm}^{-1}, 1397 \mathrm{~cm}^{-1}, 1642 \mathrm{~cm}^{-1}, 1651 \mathrm{~cm}^{-1}$ e $2851 \mathrm{~cm}^{-1}$.

Para cada conjunto de linhagens celulares foram formuladas hipóteses as quais foram associadas a particularidades bioquímicas de determinados grupos de doenças (tais como a hiperexpressão de genes e proteínas). Embora tais alterações não sejam as únicas presentes num processo de neoplasia, tais hipóteses foram utilizadas com o intuito de ilustrar possibilidades através das quais pudessem ser justificados o aumento da área de bandas de absorção referentes à uma determinada macromolécula.

As diferenças encontradas, relacionadas com o deslocamento dos picos das bandas de absorção foram associadas a alterações de caráter conformacional das moléculas, como por exemplo, um maior enovelamento da molécula de DNA acarretado por certas características biológicas de uma determinada patologia ou ainda, alterações da síntese dos lipídeos os quais compõem a membrana plasmática de determinado grupo celular.

De maneira complementar a caracterização das amostras, foi realizada uma análise de razões entre diversas bandas de absorção previamente identificadas. Através da análise das razões das bandas, buscaram-se índices capazes de diferenciar as linhagens não somente dentro de um mesmo grupo patológico e sim, comparando-as como um todo.

Foram calculadas as razões estabelecidas e utilizadas pela literatura, sendo estas entre as bandas $1650 \mathrm{~cm}^{-1}$ e $1540 \mathrm{~cm}^{-1}, 1650 \mathrm{~cm}^{-1}$ e $1740 \mathrm{~cm}^{-1}, 1650 \mathrm{~cm}^{-1}$ e $1084 \mathrm{~cm}^{-1}$ e por fim, entre a bandas de absorção situada em cerca de $1120 \mathrm{~cm}^{-1}$ e $1084 \mathrm{~cm}^{-1}$.

Uma vez que, em geral, as razões adotadas na literatura não são capazes de diferenciar efetivamente grupos contendo mais do que dois tipos de amostras biológicas, novas razões foram propostas e testadas, agrupando-se as oito linhagens estudas.

As combinações que satisfizeram a condição de diferenciar todas as linhagens foram:(i) $1053 \mathrm{~cm}^{-1}$ e $1084 \mathrm{~cm}^{-1}$; (ii) $1540 \mathrm{~cm}^{-1}$ e $10840 \mathrm{~cm}^{-1}$; (iii) $1650 \mathrm{~cm}^{-1}$ e $1084 \mathrm{~cm}^{-1}$; (iv) $1395 \mathrm{~cm}^{-1}$ e $1053 \mathrm{~cm}^{-1}$; (v) $1453 \mathrm{~cm}^{-1}$ e $1053 \mathrm{~cm}^{-1}$; (vi) $1084 \mathrm{~cm}^{-1}$ e $1646 \mathrm{~cm}^{-1}$; (vii) $1084 \mathrm{~cm}^{-1}$ e $2851 \mathrm{~cm}^{-1}$ e, por fim, (viii) $1053 \mathrm{~cm}^{-1}$ e $3060 \mathrm{~cm}^{-1}$.

Como perspectivas para o futuro, acreditamos que o enfoque deverá ser com relação a um aumento no número de amostras pertencentes a um mesmo grupo patológico, e através disso buscar definir parâmetros chave na caracterização de determinados conjuntos; uma vez definidos com maior precisão estes parâmetros, é possível investir em uma eventual disposição e combinação da informação fornecida pela espectroscopia por FTIR com informações obtidas através de outras técnicas, como por exemplo, uma análise histopatológica, enriquecendo a compreensão dos mecanismos bioquímicos envolvidos em diferentes tipos de células e tecidos, tumorais e sadios. 


\section{Referências Bibliográficas}

[1] J.P. Coates. The interpretation of infrared spectra: Published reference sources. Applied Spectroscopy Reviews, 31(1):179-192, 1996.

[2] Z. Movasaghi, S. Rehman, and I. Rehman. Fourier Transform Infrared (FTIR) Spectroscopy of Biological Tissues. Applied Spectroscopy Reviews, 43(2):134-179, 2008.

[3] H.U. Gremlich and B. Yan. Infrared and Raman spectroscopy of biological materials. Marcel Dekker, 2001.

[4] H.H. Mantsch and D. Chapman. Infrared spectroscopy of biomolecules. John Wiley \& Sons Inc, 1996.

[5] B. Rigas, S. Morgello, IS Goldman, and PTT Wong. Human colorectal cancers display abnormal Fourier-transform infrared spectra. Proceedings of the National Academy of Sciences, 87(20):8140-8144, 1990.

[6] L.P. Choo, JR Mansfield, N. Pizzi, RL Somorjai, M. Jackson, WC Halliday, and $\mathrm{HH}$ Mantsch. Infrared spectra of human central nervous system tissue: diagnosis of Alzheimer's disease by multivariate analyses. Biospectroscopy, 1(2), 1995.

[7] P.G.L. Andrus and R.D. Strickland. Cancer grading by Fourier transform infrared spectroscopy. Biospectroscopy, 4(1):37-46, 1998.

[8] J.C. Maxwell. The Scientific Papers and Letters of James Clerk Maxwell, edited by PM Harman, 2002.

[9] M. Faraday. Experimental researches in electricity. Nineteenth series. Philosophical Transactions of the Royal Society of London, pages 1-20, 1846.

[10] P.M. Harman. The Natural Philosophy of James Clerk Maxwell. Cambridge Univ Pr, 2001.

[11] W.O. George, P.S. Mcintyre, D.J. Mowthorpe, and ACOL (Project. Infrared spectroscopy. Wiley New York, 1987.

[12] I. Newton. Opticks. Dover Publications, 1952.

[13] D.J. Griffiths and C. Inglefield. Introduction to electrodynamics. Prentice Hall Englewood Cliffs, NJ, 1999.

[14] RS Shankland. Michelson-Morley Experiment. American Journal of Physics, 32:16, 1964. 
[15] M. Planck. The theory of heat radiation. Amer Inst of Physics, 1988.

[16] J.S. Rigden. Einstein 1905: the standard of greatness. Harvard University Press, 2005 .

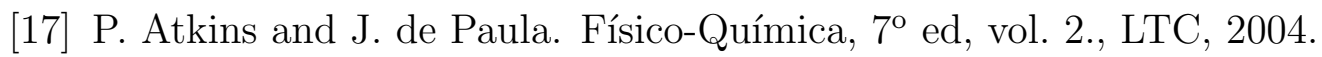

[18] W. Herschel. Experiments on the Refrangibility of the Invisible Rays of the Sun. By William Herschel, LL. DFRS. Philosophical Transactions of the Royal Society of London, pages 284-292, 1800.

[19] J.R. Dyer. Aplicações da espectroscopia de absorção aos compostos orgânicos. 1965.

[20] H. Günzler and H.U. Gremlich. IR spectroscopy: an introduction. Wiley-Vch Weinheim, 2002.

[21] J.S. Bendat. Principles and applications of random noise theory. Wiley, 1958.

[22] E.W. Ciurczak. Principles of near-infrared spectroscopy. Practical Spectroscopy Series, 13:7-7, 1992.

[23] S. Johnston. Fourier transform infrared: a constantly evolving technology. E. Horwood, 1991.

[24] P.R. Griffiths, H.J. Sloane, and R.W. Hannah. Interferometers vs monochromators: Separating the optical and digital advantages. Applied Spectroscopy, 31(6):485-495, 1977.

[25] N. Sheppard, RG Greenler, and PR Griffiths. A theoretical discussion of the comparative performances of dispersion and Fourier-transform interferometric spectrometers for the infrared region. Applied Spectroscopy, 31(5):448-450, 1977.

[26] J. Sawatzki. Fourier transform Raman microspectroscopy. Fresenius'Journal of Analytical Chemistry, 339(5):267-270, 1991.

[27] D.R. Mattson. Sensitivity of a fourier transform infrared spectrometer. Applied Spectroscopy, 32(4):335-338, 1978.

[28] PB Fellgett. PHD Ofhesis. Universety of Cambridge, 1951.

[29] P. Jacquinot. How the search for a throughput advantage led to Fourier transform spectroscopy. Infrared Phys, 2(3):99-101, 1984.

[30] S. Wartewing. IR and Raman spectroscopy fundamental processing, 2003.

[31] B. Alberts. Essential cell biology. Garland Science, 2003.

[32] B. Alberts, D. Bray, J. Lewis, M. Raff, K. Roberts, and J.D. Watson. Molecular biology of the cell. New York: Garland Science, 2002.

[33] D. Voet, J.G. Voet, and C.W. Pratt. Fundamentals of biochemistry. Wiley New York, 1999.

[34] A.L. Lehninger, D.L. Nelson, and M.M. Cox. Lehninger principles of biochemistry. WH Freeman, 2004. 
[35] A.J.F. Griffiths, S.R. Wessler, R.C. Lewontin, W.M. Gelbart, D.T. Suzuki, and J.H. Miller. Introduction to genetic analysis. WH Freeman, 2005.

[36] R.A. Weinberg and R. Allan. The biology of cancer. Garland Science New York, 2007.

[37] R.C. Bast, T.S. Gansler, J.F. Holland, and E. Frei. Cancer medicine e. 5. BC Decker, 2000.

[38] B. Vogelstein and K.W. Kinzler. The genetic basis of human cancer. McGraw-Hill Professional, 2002.

[39] CP Schultz, K.Z. Liu, PD Kerr, and HH Mantsch. In situ infrared histopathology of keratinization in human oral/oropharyngeal squamous cell carcinoma. Oncology research, 10(5):277-286, 1998.

[40] L. Brancaleon, M.P. Bamberg, T. Sakamaki, and N. Kollias. Attenuated Total Reflection-Fourier Transform Infrared Spectroscopy as a Possible Method to Investigate Biophysical Parameters of Stratum Corneum In Vivo. Journal of Investigative Dermatology, 116(3):380-386, 2001.

[41] A. Barth and C. Zscherp. What vibrations tell about proteins. Quarterly reviews of biophysics, 35(04):369-430, 2003.

[42] P.R. Griffiths and J.A. De Haseth. Fourier transform infrared spectroscopy. WileyInterscience New York, 1986.

[43] American Type Culture Collection - http://www.atcc.org/.

[44] J.M. Chalmers and P.R. Griffiths. Handbook of vibrational spectroscopy 1 - Theory and instrumentation. John Wiley \& Sons New York, 2002.

[45] J.M. Chalmers and P.R. Griffiths. Handbook of vibrational spectroscopy 3 - Sample characterization and spectral data processing. John Wiley \& Sons New York, 2002.

[46] W.K. Surewicz, H.H. Mantsch, and D. Chapman. Determination of protein secondary structure by Fourier transform infrared spectroscopy: a critical assessment. Biochemistry, 32(2):389-394, 1993.

[47] E. Benedetti, E. Bramanti, F. Papineschi, I. Rossi, and E. Benedetti. Determination of the relative amount of nucleic acids and proteins in leukemic and normal lymphocytes by means of Fourier transform infrared microspectroscopy. Applied Spectroscopy, 51(6):792-797, 1997.

[48] L. Vickery, T. Nozawa, and K. Sauer. Determination of the Secondary Structure Content of Proteins in Aqueous Solutions from Their Amide I and Amide I1 Infrared Bands. Comparison between Classical and Partial Least-Squares Methods? Biochemistry, 29:8771-8779, 1990.

[49] E. Goormaghtigh, V. Cabiaux, and J.M. Ruysschaert. Secondary structure and dosage of soluble and membrane proteins by attenuated total reflection Fouriertransform infrared spectroscopy on hydrated films. European Journal of Biochemistry, 193(2):409-420, 1990. 
[50] M. van de Weert, P.I. Haris, W.E. Hennink, and D.J.A. Crommelin. Fourier transform infrared spectrometric analysis of protein conformation: effect of sampling method and stress factors. Analytical Biochemistry, 297(2):160-169, 2001.

[51] BW Barry, HGM Edwards, and AC Williams. Fourier transform Raman and infrared vibrational study of human skin: assignment of spectral bands. Journal of Raman Spectroscopy, 23(11), 1992.

[52] A. Jemal, R. Siegel, E. Ward, Y. Hao, J. Xu, T. Murray, and M.J. Thun. Cancer statistics, 2008. CA: a cancer journal for clinicians, 58(2):71-96, 2008.

[53] SQ Wang, R. Setlow, M. Berwick, D. Polsky, AA Marghoob, AW Kopf, and RS Bart. Ultraviolet A and melanoma: a review. Journal of the American Academy of Dermatology, 44(5):837, 2001.

[54] AG Goodson and D. Grossman. Strategies for early melanoma detection: Approaches to the patient with nevi. Journal of the American Academy of Dermatology, $60(5): 719,2009$.

[55] D. Dobrosavljevic, D. Brasanac, M. Apostolovic, and L. Medenica. Changes in common melanocytic naevi after intense sun exposure: digital dermoscopic study with a 1-year follow-up. Clinical dermatology, 53(2), 2009.

[56] P.T.T. Wong, S.M. Goldstein, R.C. Grekin, T.A. Godwin, C. Pivik, and B. Rigas. Distinct infrared spectroscopic patterns of human basal cell carcinoma of the skin. Cancer Research, 53(4):762-765, 1993.

[57] R. Dahse, W. Fiedler, and G. Ernst. Telomeres and telomerase: biological and clinical importance. Clinical Chemistry, 43(5):708-714, 1997.

[58] ES Russell, SE Bernstein, and EL Green. Biology of the laboratory mouse. New York McGraw-Hill 1996.

[59] A. Rangarajan and R.A. Weinberg. Comparative biology of mouse versus human cells: modelling human cancer in mice. Nature Reviews Cancer, 3(12):952-959, 2003.

[60] D. Weinert and J. Waterhouse. Diurnally changing effects of locomotor activity on body temperature in laboratory mice. Physiology $\mathscr{E}$ behavior, 63(5):837-843, 1998.

[61] A.G. Östör. Natural history of cervical intraepithelial neoplasia: A critical review. International Journal of Gynecological Pathology, 12(2):186, 1993.

[62] PTT Wong, RK Wong, TA Caputo, TA Godwin, and B. Rigas. Infrared spectroscopy of exfoliated human cervical cells: evidence of extensive structural changes during carcinogenesis. Proceedings of the National Academy of Sciences, 88(24):10988-10992, 1991.

[63] P.T.T. Wong, R.K. Wong, and M.F.K. Fung. Pressure-tuning FT-IR study of human cervical tissues. Applied Spectroscopy, 47(7):1058-1063, 1993. 
[64] G. Pecoraro, D. Morgan, and V. Defendi. Differential effects of human papillomavirus type 6,16 , and 18 DNAs on immortalization and transformation of human cervical epithelial cells. Proceedings of the National Academy of Sciences, 86(2):563$567,1989$.

[65] L. Pirisi, S. Yasumoto, M. Feller, J. Doniger, and JA DiPaolo. Transformation of human fibroblasts and keratinocytes with human papillomavirus type 16 DNA. Journal of Virology, 61(4):1061-1066, 1987.

[66] H. Pan and AE Griep. Altered cell cycle regulation in the lens of HPV-16 E6 or E7 transgenic mice: implications for tumor suppressor gene function in development. Genes \& Development, 8(11):1285, 1994.

[67] E.L. Franco, T.E. Rohan, and L.L. Villa. Epidemiologic evidence and human papillomavirus infection as a necessary cause of cervical cancer, 1999.

[68] J. Doorbar. The papillomavirus life cycle. Journal of Clinical Virology, 32:7-15, 2005.

[69] C. Desaintes, C. Demeret, S. Goyat, M. Yaniv, and F. Thierry. Expression of the papillomavirus E2 protein in HeLa cells leads to apoptosis. The EMBO Journal, 16:504-514, 1997.

[70] K. Munger, A. Baldwin, K.M. Edwards, H. Hayakawa, C.L. Nguyen, M. Owens, M. Grace, and K.W. Huh. Mechanisms of human papillomavirus-induced oncogenesis, 2004.

[71] S. Neviliappan, L. Fang Kan, T. Tiang Lee Walter, S. Arulkumaran, and PTT Wong. Infrared spectral features of exfoliated cervical cells, cervical adenocarcinoma tissue, and an adenocarcinoma cell line (SiSo). Gynecologic oncology, 85(1):170-174, 2002.

[72] B.R. Wood, M.A. Quinn, B. Tait, M. Ashdown, T. Hislop, M. Romeo, and D. McNaughton. FTIR microspectroscopic study of cell types and potential confounding variables in screening for cervical malignancies. Biospectroscopy, 4(2), 1998.

[73] BR Wood, L. Chiriboga, H. Yee, MA Quinn, D. McNaughton, and M. Diem. Fourier transform infrared (FTIR) spectral mapping of the cervical transformation zone, and dysplastic squamous epithelium. Gynecologic Oncology, 93(1):59-68, 2004.

[74] M. Rousset, H. Paris, G. Chevalier, B. Terrain, J.C. Murat, and A. Zweibaum. Growth-related enzymatic control of glycogen metabolism in cultured human tumor cells. Cancer Research, 44(1):154-160, 1984.

[75] R. Clarke, RB Dickson, and ME Lippman. Hormonal aspects of breast cancer: growth factors, drugs and stromal interactions. Critical reviews in oncology/hematology, 12(1):1-23, 1992.

[76] G. Early Breast Cancer Trialists' Collaborative. Systemic treatment of early breast cancer by hormonal, cytotoxic, or immune therapy. Lancet, 339:71-85, 1992. 
[77] J.M. Harvey, G.M. Clark, C.K. Osborne, and D.C. Allred. Estrogen receptor status by immunohistochemistry is superior to the ligand-binding assay for predicting response to adjuvant endocrine therapy in breast cancer. Journal of Clinical Oncology, 17(5):1474, 1999.

[78] LE Rutqvist, B. Cedermark, T. Fornander, U. Glas, H. Johansson, B. Nordenskjold, S. Rotstein, L. Skoog, A. Somell, and T. Theve. The relationship between hormone receptor content and the effect of adjuvant tamoxifen in operable breast cancer. Journal of Clinical Oncology, 7(10):1474, 1989.

[79] G. Arpino, H. Weiss, A.V. Lee, R. Schiff, S. De Placido, C.K. Osborne, and R.M. Elledge. Estrogen receptor-positive, progesterone receptor-negative breast cancer: association with growth factor receptor expression and tamoxifen resistance. jnci, 97(17):1254-1261, 2005.

[80] J.C. Keen and N.E. Davidson. The biology of breast carcinoma. Cancer, 97, 2003.

[81] C.K. Osborne, M.G. Yochmowitz, W.A. Knight III, and W.L. McGuire. The value of estrogen and progesterone receptors in the treatment of breast cancer. Cancer, 46, 1980 .

[82] ME Lippman, CK Osborne, R. Knazek, and N. Young. In vitro model systems for the study of hormone-dependent human breast cancer, 1977.

[83] M.A. Ramirez, R. Gutierrez, MA Ramos, JM Silva, J. Silva, F. Bonilla, JJ Sanchez, and JC Lacal. Increased choline kinase activity in human breast carcinomas: clinical evidence for a potential novel antitumor strategy. Oncogene, 21(27):4317, 2002.

[84] E.O. Aboagye and Z.M. Bhujwalla. Malignant Transformation Alters Membrane Choline Phospholipid Metabolism of Human Mammary Epithelial Cells 1, 1999.

[85] G. Eliyahu, T. Kreizman, and H. Degani. Phosphocholine as a biomarker of breast cancer: Molecular and biochemical studies. International Journal of Cancer, 120(8), 2007.

[86] Instituto Nacional de câncer http://www.inca.gov.br/estimativa/2008/.

[87] C.P. Schultz, K. Liu, J.B. Johnston, and H.H. Mantsch. Study of chronic lymphocytic leukemia cells by FT-IR spectroscopy and cluster analysis. Leukemia research, 20(8):649-655, 1996.

[88] K.Z. Liu, M.H. Shi, and H.H. Mantsch. Molecular and chemical characterization of blood cells by infrared spectroscopy: a new optical tool in hematology. Blood Cells, Molecules and Diseases, 35(3):404-412, 2005.

[89] K.Z. Liu, M. Xu, and D.A. Scott. Biomolecular characterisation of leucocytes by infrared spectroscopy. British journal of haematology, 136(5):713, 2007.

[90] A. Elliott and J. Ambrose. Evidence of chain folding in polypeptides and proteins. Discuss. Faraday Soc., 9:246-251, 1950.

[91] M. Jackson and H.H. Mantsch. The use and misuse of FTIR spectroscopy in the determination of protein structure. Critical reviews in biochemistry and molecular biology, 30(2):95-120, 1995. 


\section{Glossário}

Abs

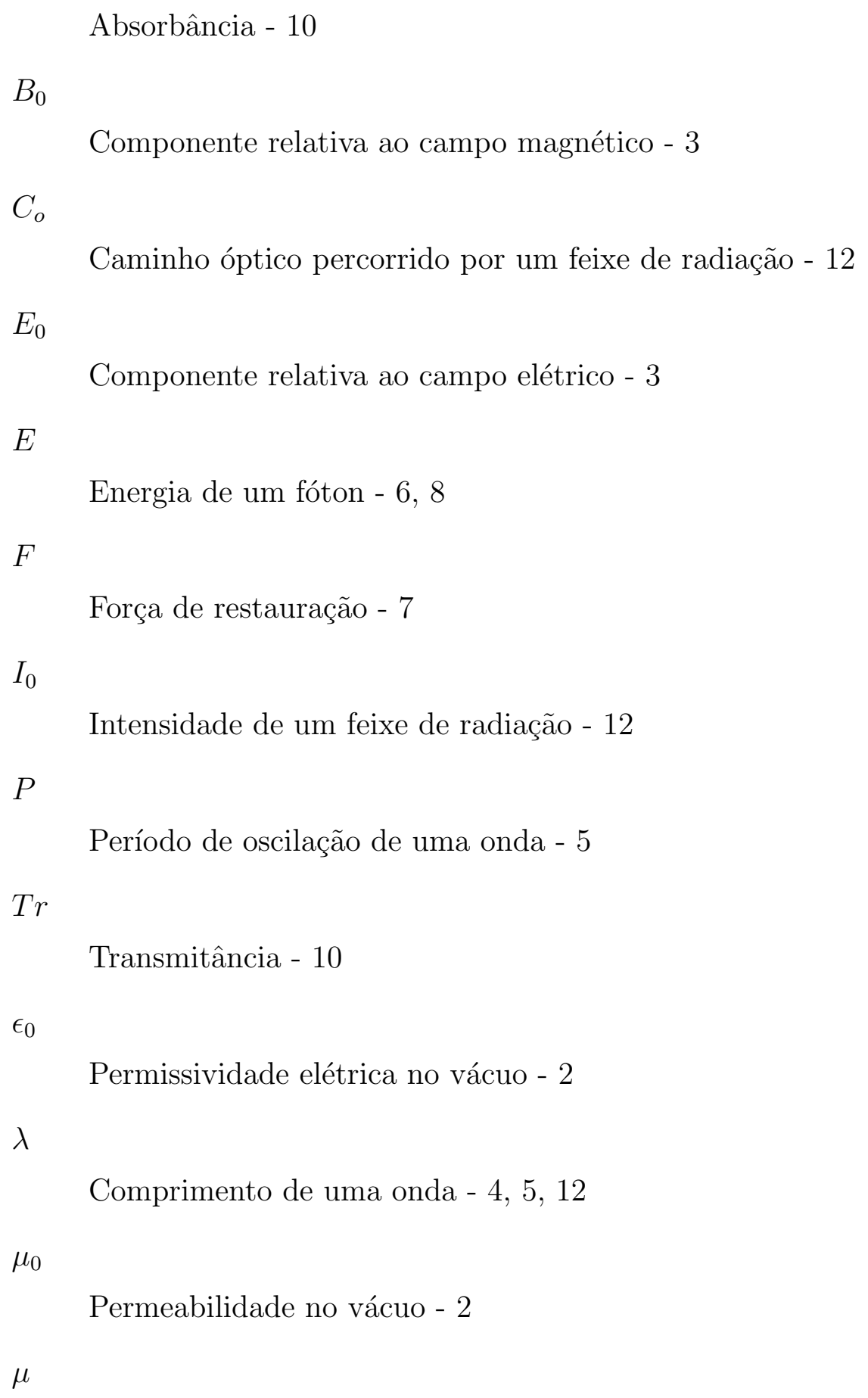

Massa reduzida dos átomos que compõem uma determinada molécula - 8 
$\nu_{e}$

Freqüência vibracional de ressonância de uma molécula - 8

$\nu$

Freqüência de uma onda - 4-8, 12, 14, 16

$c_{s}$

Velocidade de deslocamento do espelho - 13, 14

$c$

Velocidade da luz no vácuo - 2, 4, 5, 10

$f$

Constante de resistência de uma mola - 7, 8, 10

$h$

Constante de Planck - 6, 8

$k$

Número de onda - 5

$m$

Massa de um átomo - 8

$n$

Índice de refração de um meio - 4, 5

$p$

Momento de dipolo - iii, 7

$r_{e}$

Posição de equilíbrio - 7

$u$

Energia transportada por uma onda eletromagnética - 3

$x$

Deslocamento das massas a partir de uma posição de equilíbrio - 7

A

Adenina, nucleotídeo composto por uma base nitrogenada do tipo purina - iv, 23, 24

ATCC

American Type Culture Collection, banco de células situado em Manassas,Virgínia (EUA) - iii, v, 30 
ATP

adenosina trifosfato, é um nucleotídeo responsável pelo armazenamento de energia proveniente da respiração celular e da fotossíntese, nas ligações entre os grupos fosfato $-52,68$

\section{$\mathrm{B} 16 \mathrm{~F} 10$}

Linhagem celular de melanoma murino, extraída de camundongos do tipo C57BL/6J

- iii, v, ix, x, 30-32, 45, 49, 78, 84

\section{$\mathrm{BCL}-2$}

Proto-oncogene humano localizado no cromossomo 18; este suprime a apoptose celular em uma variedade de sistemas, incluindo células do sistema linfohematopoiético e células neurais. Também regula o controle da morte celular e permeabilidade da membrana - 74

C

Citosina, nucleotídeo composto por uma base nitrogenada do tipo pirimidina - iv, $\mathrm{v}, 23,24,47$

C57BL/6J

Camundongo do qual foi extraída a linhagem celular B16F10 (melanoma) - 30

\section{C8161}

Linhagem celular de melanoma humano - iii, v, ix, x, 30-32, 41, 45, 47, 49, 78, 84

CEA

Antígenos carcino-embriônicos - 30

\section{ChoK}

Enzima que catalisa a reação química entre a ATP e a colina, gerando a fosfocolina $-68$

\section{DNA}

Ácido desoxirribonucléico - iii-vii, 23, 24, 26, 39-42, 44, 45, 47, 48, 50, 53, 57-60, $64,66,67,69,71,72,74,80-84,89,90$

\section{Dulbeccos-S}

Meio de cultura, sem vermelho de fenol suplementado com soro bovino fetal, Lglutamina, bicarbonato de sódio, penicilina e estreptomicina - 32, 37

\section{E2}

Proteína que desempenha um papel central no ciclo de vida viral, uma vez que regula tanto transcrição quanto a replicação do genoma do vírus - 59

\section{E6}

Proteína, que transforma o ciclo celular de crescimento da célula hospedeira, ligandose à proteína supressora de tumores p53 - 59 


\section{E7}

Proteína que transforma o ciclo celular de crescimento da célula hospedeira, ligandose à proteína pRB/p107 a qual funciona como uma inibidora da proliferação celular $-59$

\section{EGF}

Fator de crescimento epidérmico - v, 51, 66

\section{EGFR}

Receptor do fator de crescimento epidérmico - v, 51

ER

Receptores de estrogênio (ER- "Estrogen receptors"). Estes referem-se a um grupo de receptores que são ativados pelo hormônio 17 $\beta$-estradiol (estrogênio). Embora os receptores de estrogênio possuam diversas funções, a principal é a atuação como um fator de transcrição de DNA, o qual regulamenta expressão gênica - x, 31, 42, $63,67,68,78$

\section{FAS}

"Fatty acid synthase", enzima, cuja função dentre outras, é responsável pela síntese de ácidos graxos - 75, 76

FC

Fator de crescimento, é um conjunto de substâncias sendo a maioria de natureza protéica, que atuam na comunicação intercelular juntamente com os hormônios e neurotransmissores - 66

FT

Transformada de Fourier - 11, 14-16

FTIR

Fourrier Transform Infrared Spectroscopy - iii-vi, 27, 29-31, 44, 53, 77, 80, 89, 90

Ficoll

Polissacarídeo hidrofílico que separa os diversos componentes do sangue, através da formação de um gradiente de densidade - iv, 31-33

G

Guanina, nucleotídeo composto por uma base nitrogenada do tipo purina - iv, v, $23,24,47$

GDP

Guanosina-di-fosfato, molécula a qual com a adiação de um fosfato pode ser convertido em GTP- 52

GTP

Guanosina-tri-fosfato, molécula semelhante ao ATP, utilizada para armazenar e fornecer energia celular - v, 51, 52 
Glc

Glicogênio, o qual é um polissacariídeo composto por moléculas de glicose - 18

\section{HEPES}

Agente tamponizante, amplamente utilizado em cultura de células, uma vez que é capaz de manter o pH fisiológico apesar das mudanças na concentração de dióxido de carbono (produzido pela respiração celular), quando comparado com tampão de bicarbonato - 31

HPV

"Human papillomavirus", DNA-vírus não cultivável do grupo papovavírus; são conhecidos mais de 70 tipos, 20 dos quais podem infectar o trato genital, estando divididos em 3 grupos, de acordo com seu potencial de oncogenicidade. Os tipos de alto risco oncogênico, quando associados a outros co-fatores, têm relação com o desenvolvimento das neoplasias intra-epiteliais e do adenocarcinoma de cérvix vi, 54, 57-60

HT-29

Linhagem celular de adenocarcinoma coloretal humano - iii, v, vi, ix, x, 30, 32, 55, $56,59,61,78,84$

HeLa

Linhagem celular de adenocarcinoma de cérvix humano - iii, v, vi, ix, x, 30, 32, $55-57,59-61,78,84$

IGF-1

"Insulin-like growth factor 1", ou fator de crescimento do tipo insulina 1, é um hormônio com estrutura molecular semelhante à insulina. Este desempenha um papel importante no crescimento infantil e continua a ter efeitos anabólicos em adultos - 66, 67

IGF-2

"Insulin-like growth factor 2", ou ou fator de crescimento do tipo insulina 2, é um hormônio com estrutura molecular semelhante à insulina - 66, 67

$\lg \mathrm{A}$

Imunoglobulina A - 30

JURKAT

Linhagem celular leucemia humana tipo T - iii, v, x, 31, 70-75, 78, 84

\section{MAPK}

Proteína quinase mitogênica ativada, são proteínas específicas que respondem a estímulos extracelulares (mitógenos) e regulam várias atividades celulares, como a expressão gênica, mitose, diferenciação, sobrevivência celular e apoptose - v, 51, 52

\section{MCF-7}

Linhagem celular de câncer de mama humano, com receptores de estrogênio positivo - iii, v, ix, x, 30-32, 63-68, 78, 79, 84 


\section{PBMC}

Células mononucleares de sangue periférico humano ("Peripherical Blood Mononuclear Cells") - iii-v, vii, x, 30-33, 70, 71, 73-76, 78, 79, 84

PCho

Fosfocolina, é obtida a partir de uma reação, catalisada pela colina quinase, que converte ATP e colina em fosfocolina e ADP - 68

PP2A

Proteína fosfatase $2 \mathrm{~A}$, membro expresso da família serina-treonina fosfatase a qual está envolvida com a regulação de diversos processos celulares, tais como transcrição, translação, metabolismo celular e apoptose - 50

RB

Via intracelular a qual inibe a ação de fatores de transcrição responsáveis por genes envolvidos na regulação do ciclo celular, replicação do DNA e ativação da via apoptótica - 50

RNA

Ácido ribonucléico - iii-v, vii, 23, 24, 39, 40, 45, 64, 67, 71, 80-82, 89

\section{RPMI 1640}

Mistura de sais enriquecidos com aminoácidos, vitaminas e outros componentes essenciais para o crescimento celular - 31

\section{RPMI-I}

"Roswell Park Memorial Institute" (RPMI), meio de cultura do tipo RPMI 1640 incompleto, ou seja, não contendo soro bovino fetal - 32

\section{RPMI-S}

"Roswell Park Memorial Institute" (RPMI), meio de cultura do tipo RPMI 1640, sem vermelho de fenol suplementado com soro bovino fetal, L-glutamina, bicarbonato de sódio, penicilina e estreptomicina - 31-33, 37

Raf

Gene que codifica para uma proteína quinase - v, 51, 52

\section{Ral-GEF}

"Ral guanine exchange factors", via sinalizadora associada à tumorigênese e metástase $-50$

Ras

Proteína a qual encontra-se diretamente relacionada com o receptor catalítico tirosino-quinase - v, 51, 52 


\section{Ras-Raf-MAPK}

Sistema de processos químicos celulares básicos (ou via sinalizadora) de indução mitótica, composta por proteínas as quais são reguladoras de uma variedade de processos celulares tais como proliferação, diferenciação, transporte intracelular e regulação da arquitetura celular - v, 50, 51

\section{$\mathrm{SKBr} 3$}

Linhagem celular de câncer de mama humano, com receptores de estrogênio negativo - iii, v, vi, ix, x, 31, 32, 63-65, 67, 68, 78, 84

\section{$\mathrm{T}$}

Timina, nucleotídeo composto por uma base nitrogenada do tipo pirimidina - iv, 23,24

TGF- $\alpha$

Fator de crescimento transformador-alfa, atua sinergisticamente com o TGF- $\beta$ na indução de transformação fenotípica, porém seu papel fisiológico é desconhecido 67

TGF- $\beta$

Fator de crescimento transformador-beta, controla a proliferação, diferenciação celular, dentre outras funções na maioria das células - 67

\section{TURK}

Ácido acético a 3\% - iv, 33

U

Uracila, nucleotídeo composto por uma base nitrogenada do tipo pirimidina - iv, 23,24

UV

Radiação ultravioleta - 44

p53

Gene supressor de tumores, o qual codifica uma proteína essencial para o controle do ciclo celular - 50 